\title{
WPS3497
}

\section{What Does Regional Trade in South Asia Reveal about Future Trade Integration? \\ Some Empirical Evidence}

\author{
Nihal Pitigala*
}

World Bank Policy Research Working Paper 3497, February 2005

The Policy Research Working Paper Series disseminates the findings of work in progress to encourage the exchange of ideas about development issues. An objective of the series is to get the findings out quickly, even if the presentations are less than fully polished. The papers carry the names of the authors and should be cited accordingly. The findings, interpretations, and conclusions expressed in this paper are entirely those of the authors. They do not necessarily represent the view of the World Bank, its Executive Directors, or the countries they represent. Policy Research Working Papers are available online at http://econ.worldbank.org.

*Consultant, International Trade Team (DECRG). I am particularly grateful to Garry Pursell, Alexander Yeats, Simon Evenett and seminar participants at the World Bank for comments and suggestions for improvements. 


\begin{abstract}
In 1995, the seven South Asian countries-Bangladesh, Bhutan, India, the Maldives, Nepal, Pakistan, and Sri Lanka-initiated a multilateral framework for region-wide integration under the South Asian Preferential Trade Agreement (SAPTA). In a recent initiative, members agreed that SAPTA would begin the transformation into a South Asian Free Trade Area (SAFTA) by the beginning of 2006, with full implementation completed between 2009 and 2013. The impetus toward regional preferential trading arrangements and greater regional economic integration raises many important issues, both for the South Asian region as a whole and for the individual countries.
\end{abstract}

The paper utilizes the "natural trading partners" hypothesis as the empirical criterion to assess the potential success of a South Asian trading bloc. Using various definitions of the "natural trading partner" hypothesis—based on "trade volume", "geographic proximity" and the "complementarity" approaches - this study demonstrates that the South Asian countries can be characterized only moderately as "natural trading partners". This characterization is, however, largely a consequence of previous impediments to trade among regional members. This study further demonstrates through additional statistical measures-including "revealed comparative advantage" indices, "trade concentration", and "trade competition" profiles-that the trade structures that have evolved among the South Asian countries may not facilitate a rapid increase in intra-regional trade.

There is evidence, however, that previous unilateral trade liberalization efforts in the South Asian countries have already had a positive impact in boosting both intra- and extraregional trade. Continuing the process of unilateral liberalization, in parallel with regional integration, would aid the South Asian countries to continue to diversify their still narrow export bases and potentially evolve new comparative advantages and complementarities that could facilitate the successful implementation of SAFTA. 


\section{Table of Contents}

List of Figures and Tables $\quad$ ii

List of Acronyms

Prologue 1

Some Conceptual Issues 3

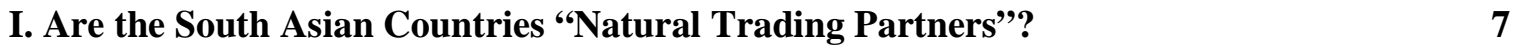

Trade Intensity and Geographical Proximity 12

II. Prospects of Intra-regional Trade: A Product-Level Assessment 20

Implications of the Divergence and Concentration of Export Structures 26

Are there Complementarities Among the South Asian Countries? 29

Complementarity Test 41

Are South Asian Countries in Competition With Each Other? 44

$\begin{array}{ll}\text { III. Conclusion } & 47\end{array}$

References $\quad 50$

Annex 1 52

$\begin{array}{ll}\text { Annex 2 } & 72\end{array}$ 


\section{List of Tables and Figures}

\section{Tables}

Table 1 Direction of South Asia's Trade, Nominal (in USD Million) 8

Table 2 Officially Recorded Intra-Regional Trade as a Share of Total Trade 9

Table 3 Trade Intensity Ratios of South Asia 14

Table 4 Ratio of Observed TIIs to Predicted TIIs 16

Table 5 Regression Coefficients: Real Trade Intensity 19

Table 6 Product Composition of SACs' Intra-regional and Extra-regional Exports (1981-98) 22

Table 7 Divergence and Concentration Summary 28

Table 8 Major Imports of South Asian Countries and Respective RCA Indices of Partner Country 34

Table 9 Trade Complementarity Index of Major SAARC Members 43

Table 10 Competition Summary $\quad 45$

\section{Figures}

Figure 1 South Asia: Real Trade Intensity (1990 \& 1998)

\section{Annex 1: Tables and Figures}

Table A1 Regional Trade as Share of Total in South Asia 52

Table A2 Nominal Intra-regional Trade, in current US dollars, fiscal 1981-98 53

Table A3 South Asia: Profile of Dynamic Exports between 1990 and 1998

Figure A1 South Asia: Changing the Distribution of Regional Exports (1990 \& 1998) 63

Table A4 Competition between South Asian Countries: Observation of Similarity among Major Exports 


\section{List of Acronyms}

$\begin{array}{ll}\text { BOP } & \text { Balance of Payments } \\ \text { RCA } & \text { International Revealed Comparative Advantage } \\ \text { LLDC } & \text { Least Developed Country } \\ \text { MFN } & \text { Most Favored Nation } \\ \text { NIC } & \text { Newly Industrialized Countries } \\ \text { NTB } & \text { Non-Tariff Barriers } \\ \text { QR } & \text { Quantitative Restriction } \\ \text { REER } & \text { Real Effective Exchange Rate } \\ \text { ROO } & \text { Rules of Origin } \\ \text { RTA } & \text { Regional Trade Agreement } \\ \text { SACs } & \text { South Asian Countries } \\ \text { SAARC } & \text { South Asian Association for Regional Cooperation } \\ \text { SAPTA } & \text { South Asian Preferential Trade Agreement } \\ \text { SAFTA } & \text { South Asian Free Trade Agreement } \\ \text { TII } & \text { Trade Intensity Index } \\ \text { WTO } & \text { World Trade Organization }\end{array}$




\section{Prologue}

South Asia is home to over 20 percent of the world's population but accounts for only 1.5 percent of world GDP and just over 1 percent of world trade. The region was one of the most protected until the late 1980s due to the prolonged use of import-substitution policies backed by restrictive trade and industrial regimes. However, since 1990, South Asia has moved in line with changes in world economic trends. It has made much progress in deregulation, and liberalization has helped to increase the region's integration with the world economy and to attain higher growth rates. Until recently, the focus of South Asia's trade liberalization efforts has been unilateral. However, in recent years, the region has made attempts to foster increased trade through a series of bilateral agreements, mainly between India and its neighbors, and multilateral agreements, such as the Bangkok Agreement. In 1995, the seven South Asian countriesBangladesh, Bhutan, India, the Maldives, Nepal, Pakistan, and Sri Lanka—turned over a new leaf in regional trade relations by initiating a multilateral framework for region-wide integration under the South Asian Preferential Trade Agreement (SAPTA). ${ }^{1}$ In a recent initiative, members agreed that SAPTA would begin the transformation into a South Asian Free Trade Area (SAFTA) by the beginning of 2006, with full implementation completed between 2009 and 2013. The initiatives for SAPTA and SAFTA are a departure from previous accords that had narrower mandates to increase regional trade and protracted negotiations on the removal of barriers to trade.

The impetus toward regional preferential trading arrangements and greater regional economic integration raises many important issues, both for the South Asian region as a whole and for the individual countries. Although economists have studied these issues, including the policy options and empirical consequences of both preferential trading arrangements (PTAs) and

\footnotetext{
${ }^{1}$ See Pursell and Pitigala (2001) for a detailed account of the motives and basic tenets of various trade agreements accorded between the South Asian countries.
} 
free trade agreements (FTAs) in other parts of the world, so far there has been little systematic work that could inform the continuing and expanding negotiations in South Asia. There have been several important studies of regional South Asian trade, some completed in the mid-1990s, prior to the recent drive toward SAFTA and the formation of bilateral FTAs within South Asia. ${ }^{2}$ There is a general lack of information about the structure of recent trends in trade and what they imply about the prospects for further regional integration.

This paper is part of a larger study under "South Asia's Trade Integration: Policies and Prospects Program," a joint initiative of the trade team of the World Bank and PREM Sector Unit on South Asia (SASPR). The main objective of this paper is to evaluate whether South Asia possesses certain fundamental conditions (defined by empirical evidence) to become a successful trading bloc. It should be noted, however, that this paper deals solely with static trade effects. Many economists have argued that the benefits of an FTA, such as SAFTA, stem from dynamic gains, such as increased foreign direct investment to smaller countries, greater political stability and cooperation, and/or enhanced credibility of reform efforts. These issues, however, are not under the purview of this paper. While this paper does not directly address the net welfare effect of trade creation and trade diversion, it relates to these effects as implied by the various conceptual propositions.

It must be noted at the outset that official accounts of South Asia's international trade statistics are flawed by the high incidence of informal trade between India and its neighbors. Available estimates (for selected years) suggest that informal trade is even higher than officially recorded bilateral trade between India and its neighbors. ${ }^{3}$ However, these estimates are based on surveys carried out prior to 1995 . It should be noted that it is likely that unilateral trade reforms

2 Srinivasan and Canonero. (1994, 1997) and Pigato, Farah, Itakura, Jun, Martin, Murrel and Srinivasan (1997), and recent studes include Panagariya (2001) and Mukherji (2001).

${ }^{3}$ Taneja (1999) for estimates of informal trade between India and its neighbors. It must be noted these estimates are based on surveys carried out incorporating important smuggling centers and extrapolated to arrive at national figures. Thus, they are prone to higher margins of error. 
undertaken by India and its neighbors since 1995 may have had some impact on diverting informal trade to formal channels such that any increase in intra-regional trade may simply reflect this transfer rather than a real increase in the total volume of intra-regional trade. Therefore, the following analysis must take this possibility into account.

\section{Some Conceptual Issues}

A series of recent studies on regional integration provides relevant empirical findings and insights on the conceptual criteria for successful regional trading arrangements. ${ }^{4}$ Long before the recent wave of PTAs and FTAs, Lipsey (1960) put forward the hypothesis of "natural trading partners," suggesting that the higher the proportion of trade with the region, and the lower the proportion with the rest of the world, the more likely is a regional agreement to raise welfare effects. Summers (1990) reinforced the "natural trading partner" argument, hypothesizing that "to the extent that blocs are created between countries that already trade disproportionately with each other, the risk of trade diversion is significantly reduced."

While the natural trading partner hypothesis has provided a popular argument and is based on the volume of trade, the hypothesis ignores the effects of trade policy, transport logistics, and other considerations, such as complementarity and competitiveness issues, which are all-important factors that can determine the success or failure of a PTA.

Wonnacott and Lutz (1989) present a modified version of the natural trading partner hypothesis by incorporating location and transportation costs. They find an increasing tendency for countries to trade with other countries in geographical proximity. Deardorff and Stern (1994), also referring to transport costs, suggest that geographical proximity between countries tends to reduce trade diversion.

\footnotetext{
${ }^{4}$ See De Melo, Panagariya and Rodrick (1993), Winters (1996), Schiff (1993 and 2001), and World Bank (1995, 1999).

${ }^{5}$ Disproportionality is defined as a higher proportion of trade within a regional bloc compared to the ROW.
} 
Schiff (1999) argues that the volume of trade does not necessarily provide an objective measure of the extent to which trading partners are "natural." The reason for this is that the volume of trade is itself affected by trade policy. Schiff (1999) introduces a version of the natural trade hypothesis that is independent of trade policy. He proposes a definition of natural trading partners as a situation characterized by complementarity rather than substitutability. If a country imports what its trading partner exports, Schiff concludes that the hypothesis of "natural trading partner" is likely to hold.

Proponents who utilize statistical measures such as the complementarity index argue that the higher the observed values of the index between partners, the more likely is it that a proposed regional trade agreement will succeed (Michaely, 1996). Furthermore, a substantial empirical literature refers to the existence of complementarity rather than competitive trade as a precondition needed to enhance the probability of a net trade-creating, rather than net tradediverting, regional trade arrangement. ${ }^{6}$ Countries with different comparative advantage profiles should, in principle, have more opportunities to trade with each other compared with those with similar comparative advantage profiles.

Lastly, the empirical literature refers to the impact of concentration and diversification of exports on regional trade agreements. Yeats (1998) states that studies have shown that countries with highly concentrated exports may experience a relatively high degree of instability in export earnings that could reduce a country's ability to consistently maintain financial commitments required by regional agreements.

The objective of this paper is, then, to evaluate whether South Asia's trade patterns meet the conceptual criteria outlined above, which are deemed to be necessary prerequisites for a successful FTA. The approach is based on an examination of trends and characteristics of recent

\footnotetext{
${ }^{6} \mathrm{Ng}$ and Yeats (2003), Yeats (2001).
} 
and historical "officially recorded" trade patterns and it utilizes a number of quantitative indices and statistical measures to quantify the "strengths" and "inefficiencies" in the region's trade patterns. The key questions to be addressed include the following:

- How important is South Asia as a trading partner for member countries?

- How has regional trade evolved over time with increased global integration?

- How does South Asia compare with other regional trade blocs?

- Is South Asia's export product-mix diverse enough to support further regional integration?

- How complementary are the countries' respective import-export profiles?

- What do South Asia's comparative advantages reveal about the prospects for increasing regional trade?

The paper is structured as follows. Section I undertakes a detailed evaluation of whether South Asia conforms to the "natural trading partner" hypothesis. The analysis based on the evolution of trade over the past two decades, its direction and, hence, the relative importance of (officially recorded) intra-regional trade between 1990 and 1998. First, it evaluates 'trade volume' criteria of the 'natural trading partners' hypothesis. A sub-section that follows evaluates the geographic criteria to the "natural trading partner" hypothesis, which attempts to identify whether geography is, in fact, a critical factor in South Asia's direction of trade. Section II further examines characteristics of South Asia's trade structure, focusing on whether the region's export product-mix is diverse enough to support further regional integration. Following a brief overview of regional trade at a more disaggregated level, this section assesses the 'complementarity' of intra-regional trade, an alternative approach to characterize the "natural trading partner" hypothesis and a critical prerequisite for the potential success of SAFTA. An analysis of export competitiveness between the countries follows to substantiate or dismiss the evidence of complementarity and/or the lack of it. The paper concludes with an evaluation of the problems and prospects for increasing regional trade in South Asia, and highlights some policy lessons that can guide future efforts. 


\section{Are the South Asian Countries "Natural Trading Partners"?}

Triggered by their desire for export-led development, the South Asian countries began expanding their export orientation toward industrial countries, moving from basic agricultural exports to labor-intensive manufactured exports. During the 1980s and 1990s, international conditions—-specifically the multilateral reduction of tariffs under the GATT and the diffusion of production and trade through foreign direct investment—-helped the South Asian countries in their quest to enhance their economic development through manufactured exports. As barriers began to fall, industrial countries increasingly sought to rationalize production by transferring laborintensive manufacturing to low-cost production centers and South Asia became a premier beneficiary. The effect on the textile and apparel sector has been the most notable impact of this transformation as far as South Asia has been concerned. A commanding share of manufacturing and export revenues for all South Asian countries increasingly comprised textile and apparel exports to industrial countries. Although the Multi Fiber Agreement (MFA) regime governed the textile and apparel trade, the quotas extended by industrial countries provided an adequate incentive for South Asian countries to increase trade, via both domestic and international (quotaseeking) investors. The depreciation of real effective exchange rates in the region further assisted the South Asian countries in capitalizing on favorable international conditions. ${ }^{7}$

At a broad level, the available (official) data of the major South Asian countries indicate that industrial countries continue to assume a major share of the region's trade, while developing countries outside South Asia have been the second most important group, although their importance has been steadily diminishing as seen from Table 1, below. Intra-regional trade, meanwhile, remains low despite a revival in the late 1990s.

\footnotetext{
${ }^{7}$ Pigato et al (1997).
} 
Table 1: Direction of South Asia's Trade (Constant US\$ Million, 1995)

\begin{tabular}{|c|c|c|c|c|c|c|c|c|c|}
\hline & \multicolumn{3}{|c|}{ IMPORTS } & \multicolumn{3}{|c|}{ EXPORTS } & \multicolumn{3}{|c|}{ SHARE OF TOTAL TRADE } \\
\hline & 1981 & 1990 & 1998 & 1981 & 1990 & 1998 & 1981 & 1990 & 1998 \\
\hline South Asia & 618 & 733 & 3,293 & 556 & 837 & 2,814 & 3.2 & 2.4 & 5.0 \\
\hline East Asia & 2,084 & 4,764 & 15,000 & 688 & 2,198 & 5,548 & 7.5 & 10.8 & 16.7 \\
\hline Other Developing & 11,579 & 11,868 & 21,529 & 5,624 & 8,100 & 12,523 & 46.7 & 31.1 & 27.8 \\
\hline Industrial Countries & 11,091 & 20,201 & 29,702 & 4,593 & 15,549 & 32,281 & 42.6 & 55.6 & 50.5 \\
\hline
\end{tabular}

Source: IMF Direction of Trade Statistics.

Notes: Oil imports are excluded from the South Asia's data. All Middle East, the post-Soviet Republics and Eastern European countries are categorized under "Other Developing Countries (which excludes South Asia); East Asia also includes the Rep. of Korea, Taiwan (China), and Hong Kong (China). China is among the "Other Developing" category, as it is not traditionally identified under East Asia.

The above indicates that South Asia has gradually adjusted its direction of trade as it has evolved through both domestic reform and international competitive conditions. In the process, the South Asia region, as a trading partner, has also relatively increased in importance among regional members. But how significant is this emergence and can the South Asian countries be characterized as "natural trading partners"?

Table 2 provides a review of intra-regional trade between 1981 and 1998 at an aggregate level. The overall (official) intra-regional trade as a share of total trade has remained below 5 percent throughout this period. However, these aggregate figures are biased by India's trade patterns, the dominant economy in the region, and therefore do not reflect the extent of intraregional trade of the smaller countries. There are, in fact, large differences in the relative importance of South Asian markets for individual member countries of the South Asian Association for Regional Cooperation $(\mathrm{SAARC}){ }^{8}$ For example, Bhutan and Nepal trade disproportionately with the region, with shares of regional trade as high as 71 percent and 33 percent, respectively, in 1998 as seen from Table 2. Due to the landlocked nature of these two countries, trade takes place primarily with India. While Nepal has made some efforts to reduce its

\footnotetext{
${ }^{8}$ See Annex Table A1.
} 
trade dependence on India, Bhutan remains strongly dependent on India as both a supply source and export destination. For Bangladesh and Sri Lanka, regional trade accounted for approximately 12.4 percent and 8.2 percent of their total trade, respectively, in 1998 (Table 2). Both have increased their shares of intra-regional trade since unilateral reforms were initiated by Bangladesh and continued by Sri Lanka (whose reforms were initiated as far back as 1979) in the early 1990s. For Pakistan, intra-regional trade is relatively insignificant, accounting for a modest 3.6 percent of its total trade in 1998. However, Pakistan, too, has increased its share of regional trade since it implemented reforms, increasing from 2.7 percent in 1990. For India, intra-regional trade is even less significant, accounting for a low 3.2 percent of its total trade in 1998. However, India has shown a noteworthy increase in intra-regional trade since it initiated reforms in 1990 and 1991, years when intra-regional trade accounted for a meager 1.4 percent of its total trade.

Table 2: Officially Recorded Intra-regional Trade as a Share of Total Trade

\begin{tabular}{|c|c|c|c|c|c|c|c|c|c|c|c|c|}
\hline & \multicolumn{4}{|c|}{ Intra-regional Imports } & \multicolumn{4}{|c|}{ Intra-regional Exports } & \multicolumn{4}{|c|}{ Total Intra-regional Trade } \\
\hline & 1981 & 1990 & 1995 & 1998 & 1981 & 1990 & 1995 & 1998 & 1981 & 1990 & 1995 & 1998 \\
\hline India & 1.3 & 0.4 & 0.6 & 1.1 & 2.9 & 2.7 & 5.1 & 5.6 & 1.8 & 1.4 & 2.7 & 3.2 \\
\hline Pakistan & 1.9 & 1.6 & 1.5 & 2.4 & 5.5 & 4.0 & 3.2 & 4.9 & 3.1 & 2.7 & 2.2 & 3.6 \\
\hline Bangladesh & 4.7 & 7.0 & 17.7 & 17.5 & 7.9 & 3.1 & 2.3 & 2.7 & 5.4 & 5.8 & 12.7 & 12.4 \\
\hline Sri Lanka & 5.2 & 7.0 & 11.4 & 12.9 & 8.8 & 3.7 & 2.7 & 2.4 & 6.5 & 5.6 & 7.5 & 8.2 \\
\hline Nepal & $\mathrm{N} / \mathrm{A}$ & 13.4 & 17.5 & 31.7 & 63.8 & 7.7 & 9.2 & 36.2 & 47.4 & 11.9 & 15.0 & 32.8 \\
\hline Maldives & 6 & 7.4 & 4.5 & 7.7 & 22.3 & 13.8 & 22.5 & 16.6 & 9.4 & 9.2 & 6.7 & 9.4 \\
\hline Bhutan & $\mathrm{N} / \mathrm{A}$ & 10.9 & 57.5 & 59.9 & $\mathrm{~N} / \mathrm{A}$ & 9.6 & 87.9 & 81.9 & $\mathrm{~N} / \mathrm{A}$ & 9.7 & 73.5 & 71.8 \\
\hline South Asia & 2.4 & 2.0 & 3.8 & 4.3 & 4.8 & 3.1 & 4.3 & 7.3 & 3.2 & 2.4 & 4.1 & 4.9 \\
\hline MERCOSUR & $\mathrm{N} / \mathrm{A}$ & 14.5 & 18.1 & $\mathrm{~N} / \mathrm{A}$ & 8.9 & 8.9 & 20.5 & $\mathrm{~N} / \mathrm{A}$ & 10.7 & 14.0 & 21.3 & 23.0 \\
\hline $\begin{array}{l}\text { Andean } \\
\text { Community }\end{array}$ & $\mathrm{N} / \mathrm{A}$ & 6.4 & 12.6 & 12.0 & $\mathrm{~N} / \mathrm{A}$ & 4.1 & 11.8 & 11.9 & $\mathrm{~N} / \mathrm{A}$ & 7.9 & 12.3 & 11.4 \\
\hline ASEAN & 13.2 & 14.6 & 16.9 & 20.9 & 17.2 & 18.2 & 23.4 & 19.8 & 15.2 & 16.3 & 20.0 & 20.3 \\
\hline EU (15) & 57.3 & 65.9 & 62.4 & 61.8 & 52.9 & 63.2 & 61.0 & 59.4 & 55.0 & 64.5 & 61.7 & 60.6 \\
\hline
\end{tabular}

Sources: IMF Direction of Trade Statistics.

Notes: Shares for Bhutan are based on partner data (mirror statistics). Please note the presence of discrepancies between FOB and CIF values in mirror statistics.

Intra-regional trade patterns in South Asia suggest that all members increased their relative importance in the region toward the late 1990s. ${ }^{9}$ Although the relative importance of the

\footnotetext{
${ }^{9}$ Pitigala and Baysan (2001) argue that the revival of intra-regional trade in the late 1990s has ostensibly occurred due to unilateral trade reforms rather than regional or bilateral agreements. However, increased
} 
region increased in more or less the same ratios for Bangladesh, Nepal, Pakistan, and Sri Lanka, the increases are based more on imports from the region rather than exports. The share of intraregional imports of Bangladesh increased from 7 percent in 1990 to 17.7 percent in 1998. Nepal increased its intra-regional imports from 4.0 percent to 31.7 percent, Sri Lanka from 7.0 percent to 12.9 percent, and Pakistan from 1.6 percent to 2.4 percent during the same period. However, the relative importance of intra-regional exports has been decreasing for both Bangladesh (from 3.1 percent to 2.7 percent) and Sri Lanka (from 3.7 percent to 2.4 percent) during the corresponding period and remains marginal for Pakistan. This imbalance is partly a consequence of India maintaining a higher level of border protection relative to its neighbors and partly a consequence of Bangladesh and Sri Lanka reinforcing their integration with the industrial countries.

As discussed above, the "natural trading partner" hypothesis, based on the trade volume approach, suggests that members of a regional agreement should trade disproportionately with each other in order to be a successful bloc. It appears that, despite the revival of intra-regional trade since reforms were initiated in the early 1990s, only the smaller landlocked countries can be perceived as having a "disproportionate" share of trade with the region, largely owing to their trade with India. On the other hand, neither India—-the largest economy in the region-nor the other economies in South Asia can be regarded as having a "disproportionate" share of trade with the South Asia region.

Members of other successful regional arrangements, such as the European Union and NAFTA, had levels of intra-regional trade that can be characterized as demonstrating that they are "natural trading partners." At the inception of the EU, intra-regional trade was around 65 percent, and among NAFTA members it was around 41 percent. South Asia does not compare

devaluation of the exchange rate also appears to have had a significant impact on the increase in exports, especially in the case of India. 
well, moreover, with other developing region trade blocs, such as Mercosur. For example, prior to the formal launch of Mercosur in 1991, its share of intra-regional trade stood at 14 percent. ${ }^{10}$ Similarly, in ASEAN, a relatively high level of regional trade among member countries at the launching of their regional trading arrangements - 16 percent-provided the necessary impetus for further regional integration.

If SAFTA is launched from low level of intra-regional trade, lower than any successful regional grouping, such a low base may be evidence that the South Asian countries are not, in fact, "natural trading partners." The failure to meet this key conceptual criterion for beneficial integration may adversely affect the realization of a successful FTA in the region.

The above estimates of intra-regional trade are based on official trade data, which we know understates the extent of intra-regional trade. Could the above conclusion that the South Asian countries are not natural trading partners be altered if we take into account available "guesstimates" of informal trade in the region? For example, if the reported one billion dollars' worth of informal trade between India and Pakistan cited by Taneja (1999) is incorporated, it would boost Pakistan's share of intra-regional trade to around 14 percent of its total trade (referring to 1998 survey results), although it would still fall below the level of trade it undertakes with the United States (19 percent) and the European Union (22 percent) in the corresponding year. While informal exports to India from Bangladesh, Nepal, and Sri Lanka are relatively high, they comprise a sizable share of third-country goods that originate beyond regional sources. However, these national guesstimates of informal trade based on a sample survey of key locations may have high error margins and, hence, may not be fully reliable. Even with a less conservative

\footnotetext{
${ }^{10}$ Mercosur's initial members were Argentina, Brazil, Paraguay and Uruguay. Chile and Bolivia became members in 1996 in 1997, respectively. Immediately following the establishment of a common external tariff in Mercosur in 1995, there was a sharp rise in intra-Mercosur trade, to 23 percent in 1998, almost four times as much as the share of intra-regional trade in South Asia.
} 
estimates of informal trade are accounted for it is implausible to characterize the South Asian countries as "natural trading partners" based on their trade volumes.

\section{Trade Intensity and Geographical Proximity}

It is argued that countries in relative geographical proximity tend to trade more with each other than with more distant countries owing to lower transport and communications costs (Deardorff and Stern, 1994). Wonnacott and Lutz (1989) also refer to transport costs, suggesting that geographical proximity between countries tends to increase trade between them and reduce trade diversion. Regional trade in South Asia tends to be centered around India, which, for most of the smaller countries, is the closest neighboring country. However, as demonstrated in Annex Table A1, there exists very little or no trade among the smaller countries, such as Bhutan, Maldives, and Nepal, which are in relative proximity compared with the more distant industrial countries with whom they trade more. This suggests that there may be other factors-such as transport and logistical impediments that give rise to high transaction costs, or the lack of trade complementarities—which account for the apparent low levels of trade. Taneja (2000) points out that high transaction costs induced by inefficient institutional designs are the premier factors diverting trade between India and its smaller neighbors into informal channels, circumstances that may also explain the low levels of trade between the landlocked countries and others in the region. This might imply that tariff preferences alone would not be sufficient to stimulate regional trade.

While the preceding analysis, based on broad trade trends, has shed some light on prospects for further regional integration, it would be informative to evaluate whether the South Asian countries, given the size of neighboring markets, export to the region as much as could be expected and whether regional trade, from this perspective, has changed over time. The trade intensity index (TII) is a useful tool for evaluating these questions in the context of South Asia. 
The TII reflects the increase in "trade intensity" among countries. ${ }^{11}$ Specifically, the TII can highlight the relative importance of evidently low levels of trade (in absolute terms) between countries. If the TII value is above or below unity, the countries have greater or smaller bilateral trade flows than would be expected based on the two partners' share in world trade. The TII is defined as:

$$
I_{i j}=\left(X_{i j} / X_{i}\right) /\left[M_{j} /\left(M_{w}-M_{i}\right)\right]
$$

$I_{i j}$, country $i$ 's exports to country $j$, is defined as the share of country $j$ in country $i$ 's total exports $\left(X_{i j} / X_{i}\right)$, relative to the share of $j$ 's imports, $M_{j}$, in total world imports, net of $i$ 's imports from the rest of the world $\left(M_{w}-M_{i}\right)$. For those trading partners that have TIIs greater than unity, their trade relationship can be defined as "intensive" (i.e. the countries trade more than would be expected given the relative size of the market for imports). An analysis of changes in these indices over time can show whether two countries are experiencing an increased or decreased tendency to trade with one another. An increasing tendency may reinforce prospects for further integration, while a decreasing tendency would diminish such prospects.

However, the indices will only be of limited use if we fail to take into account distance, language, culture, and religion, among other factors that may influence trade patterns - and, if possible, the TII should be adjusted to take account of all these influences. In order to account for geographical distance factor, an attempt is made to normalize the TII results by regressing for distance. The charts in Figure 1 provide a graphical representation. The charts plot the TIIs for each of the South Asian countries against the geographic proximity of each country (moving from left to right, geographic distance decreases). For those countries located above the regression line, the South Asian country in question demonstrates a "real" intensive trade relationship (i.e. the South Asian country exports more to the selected country than would be expected given both the

${ }^{11}$ See Braga, Safidi and Yeats (1994), Anderson and Blackhurst (1993) for an application within the context of RTAs. 
relative size of its import market and its geographic proximity). The results are provided for two years, 1990 and 1998, to illustrate whether the South Asian countries demonstrate an increasing or decreasing tendency to trade with one another.

Table 3: Trade Intensity Ratios of South Asia

\begin{tabular}{|l|r|r|r|r|r|r|r|r|r|r|}
\hline \multirow{2}{*}{$\begin{array}{l}\text { PARTNER } \\
\text { COUNTRY }\end{array}$} & \multicolumn{9}{|c|}{ EXPORTING COUNTRY } \\
\cline { 2 - 11 } & \multicolumn{2}{|c|}{ India } & \multicolumn{1}{|c|}{ Pakistan } & \multicolumn{1}{c|}{ Sri Lanka } & \multicolumn{1}{c|}{ Bangladesh } & \multicolumn{2}{c|}{ Nepal } \\
\hline & $\mathbf{1 9 9 0}$ & $\mathbf{1 9 9 8}$ & $\mathbf{1 9 9 0}$ & $\mathbf{1 9 9 8}$ & $\mathbf{1 9 9 0}$ & $\mathbf{1 9 9 8}$ & $\mathbf{1 9 9 0}$ & $\mathbf{1 9 9 8}$ & $\mathbf{1 9 9 0}$ & $\mathbf{1 9 9 8}$ \\
\hline India & - & -1.28 & 3.14 & 1.55 & 1.29 & 1.89 & 1.88 & 10.19 & 42.81 \\
\hline Pakistan & 1.16 & 2.28 & - & - & 8.11 & 4.09 & 6.57 & 4.58 & 1.48 & 1.10 \\
\hline Sri Lanka & 7.55 & 12.84 & 17.57 & 9.89 & - & - & 6.52 & 0.24 & 0.66 & 16.63 \\
\hline Bangladesh & 15.94 & 21.86 & 16.34 & 9.71 & 4.95 & 0.94 & - & - & 2.82 & 9.72 \\
\hline Nepal & 13.22 & 35.03 & 1.22 & 3.57 & 0.25 & 1.70 & 26.19 & 18.45 & - & - \\
\hline Maldives & 6.67 & 2.41 & 2.51 & 2.80 & 44.00 & 40.00 & $\mathrm{~N} / \mathrm{A}$ & $\mathrm{N} / \mathrm{A}$ & $\mathrm{N} / \mathrm{A}$ & $\mathrm{N} / \mathrm{A}$ \\
\hline Bhutan & 0.00 & 16.34 & 0.22 & 0.54 & $\mathrm{~N} / \mathrm{A}$ & $\mathrm{N} / \mathrm{A}$ & 2.32 & 4.36 & $\mathrm{~N} / \mathrm{A}$ & 9.04 \\
\hline \hline US & 1.02 & 1.26 & 0.84 & 1.3 & 1.75 & 2.17 & 2.06 & 2.15 & 1.58 & 1.55 \\
\hline UK & 0.98 & 1.05 & 1.16 & 1.23 & 0.89 & 1.75 & 1.12 & 1.66 & 0.90 & 0.21 \\
\hline
\end{tabular}

Note: Calculations are based on data from the IMF Direction of Trade Statistics

While the South Asian countries demonstrate TIIs (not normalized) greater than unity, some relatively increasing and some decreasing as seen from Table 3, when normalized for geographic proximity, their relative importance to each other becomes less pronounced. This is illustrates from statistics in Table 4 which reports the ratio of observed to predicted TIIs for each of the countries, thus demonstrating the magnitude of the difference in actual (not normalized) TIIs and the TII that would be predicted given the geographical distance (i.e. at a given point along the regression line). For example, India's "real" trade intensities, normalized for geographical proximity, with the other South Asian countries are stronger than that implied by its bilateral trade shares. In 1998, India traded more than 3 times as much as should have been expected with Sri Lanka, more than $5 \frac{1 / 2}{2}$ times as much as should have been expected with Bangladesh, and 8 times as much as should have been expected with Nepal.

However, for the peripheral countries, trade with the region is below what should have been expected given the size of the partners' import market and their geographical proximity. For 
example, Pakistan, Bangladesh and Sri Lanka's trade with India is less than what should have been expected. Pakistan's trade intensity with India-which appeared positive and growingonce adjusted for geographical proximity, falls below what should have been expected. Nepal is the only SAPTA member that increased its relative share of trade with India well above what should have been expected (more than 5 times). This augurs well for the prospects of the existing bilateral trade agreement between these two countries, to the extent that free trade is devoid of trade diversion. Interestingly, Pakistan is gradually moving toward a level of trade with India consistent with what should have been expected. Overall, however, the results for bilateral trade between the smaller periphery countries are unconvincing-there is no clear trend toward increased trade between them. Instead, there is evidence of diminishing levels of bilateral trade intensity between Pakistan and Bangladesh, Sri Lanka and Pakistan, Sri Lanka and Bangladesh, Bangladesh and Sri Lanka, and Nepal and Bangladesh.

More noteworthy feature of the analysis is that the South Asian countries have shown an increasing tendency to trade intensively with partners elsewhere in the world for cultural, ethnic, or religious reasons. As shown in Figure 1 Pakistan provides the strongest evidence of this pattern-its trade with more geographically distant trading partners, particularly the Islamic countries in Africa and the Middle East, has grown in importance compared with its regional partners. It is interesting to note that the destinations with high TIIs (above the regression line) shown by both India and Pakistan and, to some extent, Bangladesh, are countries with significant migrant communities from what was once Greater India. This may be evidence that cultural and linguistic affinity can be important determinants in reinforcing trade between countries that are not in geographical proximity. 
Table 4: Ratio of Observed TIIs to Predicted TIIs

\begin{tabular}{|c|c|c|c|c|c|c|c|c|c|c|}
\hline \multirow{3}{*}{$\begin{array}{l}\text { Partner } \\
\text { Country }\end{array}$} & \multicolumn{10}{|c|}{ Exporting Country } \\
\hline & \multicolumn{2}{|l|}{ India } & \multicolumn{2}{|c|}{ Pakistan } & \multicolumn{2}{|c|}{ Bangladesh } & \multicolumn{2}{|c|}{ Sri Lanka } & \multicolumn{2}{|c|}{ Nepal } \\
\hline & 1990 & 1998 & 1990 & 1998 & 1990 & 1998 & 1990 & 1998 & 1990 & 1998 \\
\hline India & & - & 0.41 & 0.92 & 0.49 & 0.76 & 0.37 & 0.40 & 5.61 & 6.07 \\
\hline Pakistan & 0.34 & 0.56 & - & - & 1.79 & 1.90 & 1.93 & 1.25 & 0.83 & 0.17 \\
\hline Bangladesh & 4.83 & 5.46 & 9.60 & 3.13 & & & 1.14 & 0.28 & 1.51 & 1.27 \\
\hline Sri Lanka & 2.37 & 3.34 & 4.17 & 3.23 & 1.76 & 0.10 & - & - & 0.41 & 22.15 \\
\hline Nepal & 3.84 & 8.50 & 0.40 & 1.08 & 6.66 & 7.30 & 0.06 & 0.51 & - & \\
\hline Maldives & 2.19 & 0.64 & 0.86 & 0.95 & $\mathrm{~N} / \mathrm{A}$ & $\bar{N} / \mathrm{A}$ & 10.01 & 11.73 & $\mathrm{NA}$ & \\
\hline Bhutan & & 4.03 & 0.07 & 0.17 & 0.58 & 1.71 & $\mathrm{~N} / \mathrm{A}$ & $\mathrm{N} / \mathrm{A}$ & $\mathrm{N} / \mathrm{A}$ & 1.18 \\
\hline$\overline{\text { US }}$ & 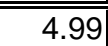 & 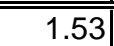 & 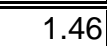 & 2.37 & "3.13 & 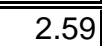 & 16.02 & 2.58 & 37.31 & 0.70 \\
\hline UK & 0.76 & 0.56 & 0.81 & 0.97 & 0.76 & 1.23 & 0.80 & 1.49 & 2.05 & 0.30 \\
\hline
\end{tabular}

Note: Calculations are based on data from the IMF Direction of Trade Statistics

Overall, the trade intensity indices and their movements from pre-reform to post-reform periods do not demonstrate a consistent positive relationship for all countries in the South Asia region. A positive increase in the TII appears only between India and Nepal; in other cases, the bilateral relationships are asymmetric and/or in decline. The evidence also supports the earlier observation that South Asia does not appear to fit the hypothesis that geography is a strong determinant of trade. Instead, those countries with which the South Asian countries demonstrate real intensive relationships (that is, those with TIIs above the regression line) tend to be well dispersed along the distance axis. The evidence of irregular, incoherent "trade intensity", given the geographic proximity and relative size of trade, cannot be interpreted as a positive sign for a rapid increase in regional trade. 
Figure 1: South Asia: Real Trade Intensity (1990 \& 1998)

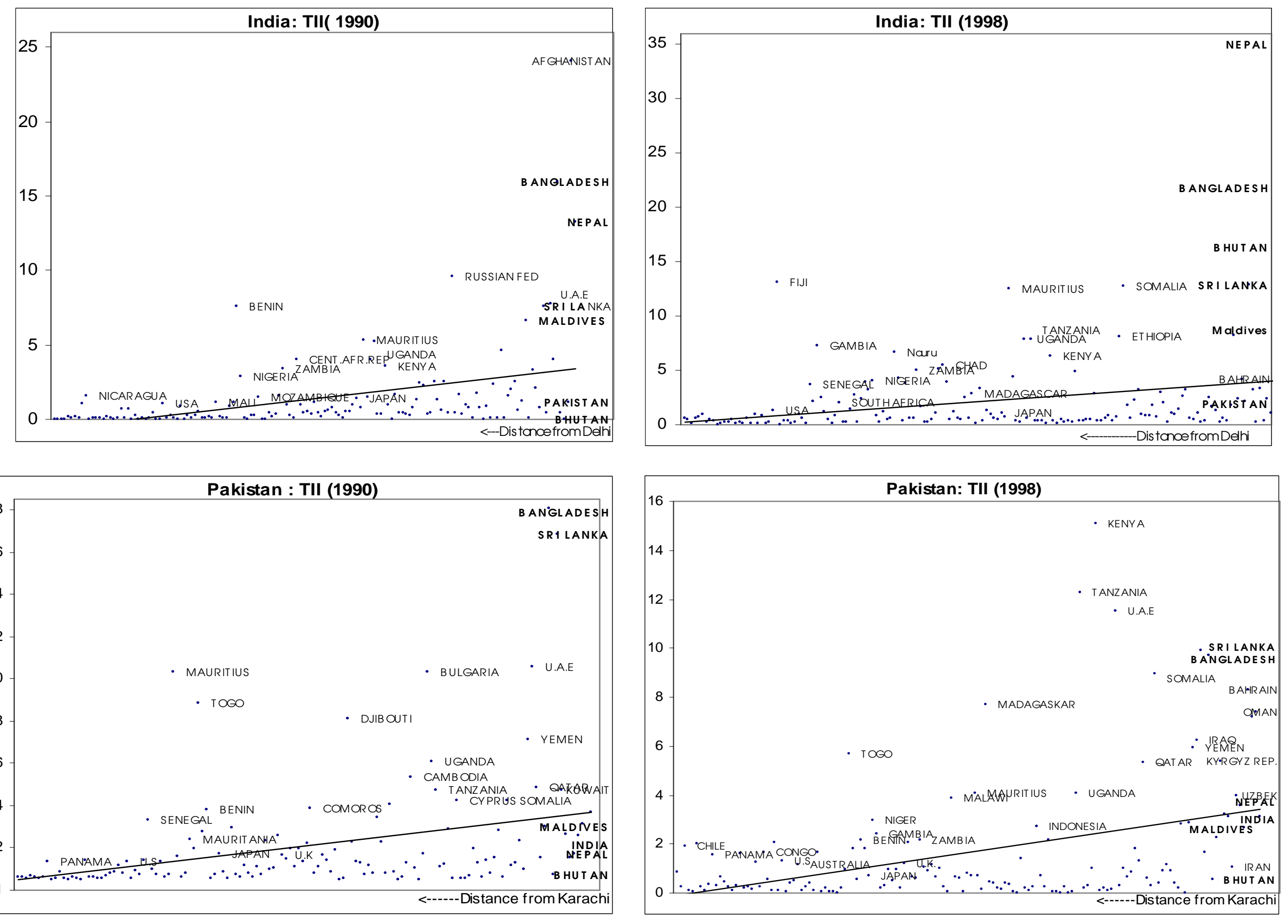



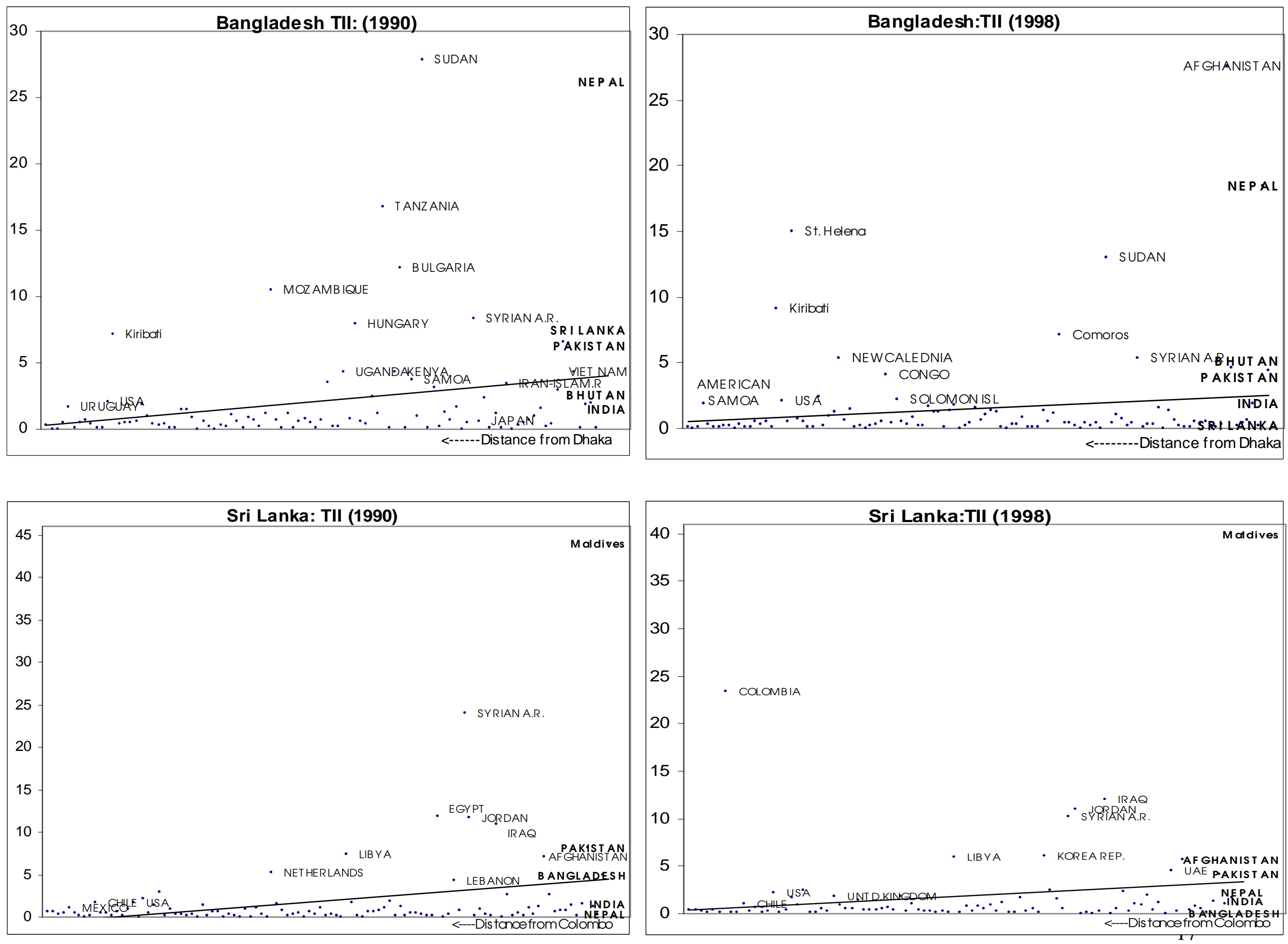

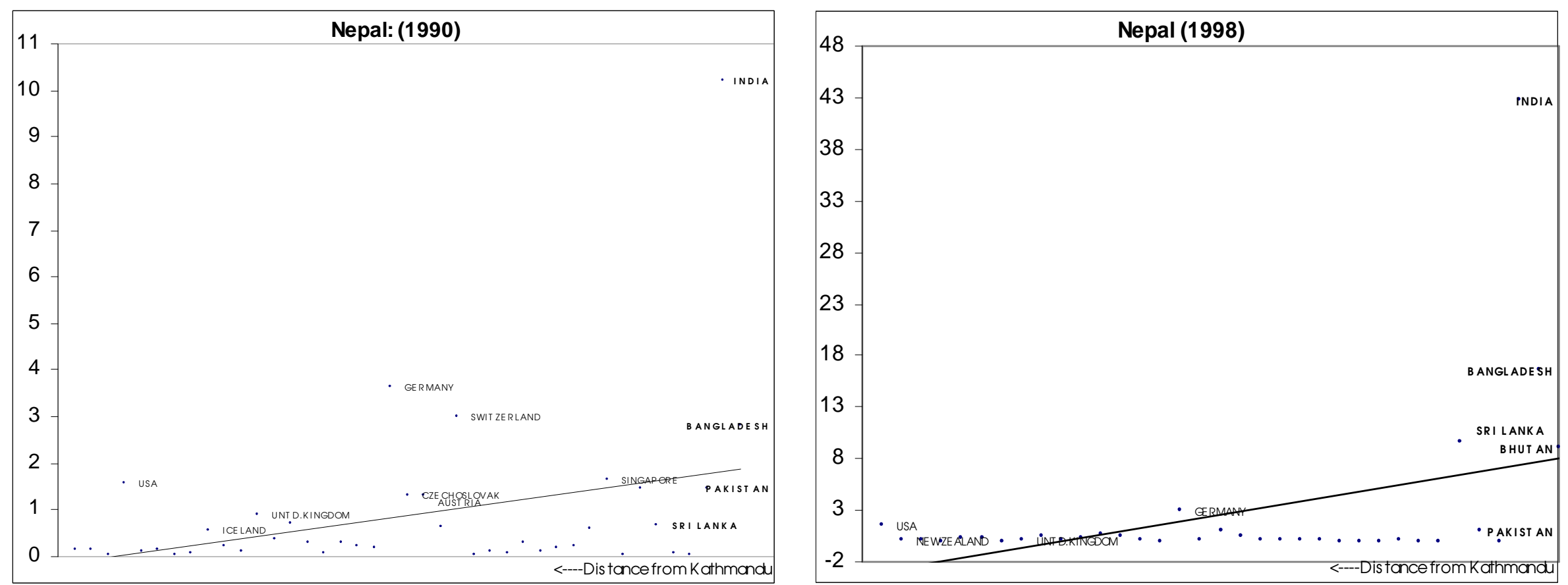

Table 5: Regression Coefficients: Real

Trade Intensity

\begin{tabular}{|l|l|l|}
\hline Country & 1990 & 1998 \\
\hline India & -0.03 & -0.02 \\
& $(0.01)$ & $(0.01)$ \\
\hline Pakistan & -0.02 & -0.02 \\
& $(0.01)$ & $(0.00)$ \\
\hline \multirow{2}{*}{ Bangladesh } & -0.04 & -0.02 \\
& $(0.01)$ & $(0.01)$ \\
\hline Sri Lanka & -0.05 & -0.03 \\
& $(0.02)$ & $(0.02)$ \\
\hline \multirow{2}{*}{ Nepal } & -0.05 & -0.29 \\
& $(0.02)$ & $(0.11)$ \\
\hline
\end{tabular}

Source: Author's calculations using Comtrade data. 


\section{Prospects of Intra-Regional Trade: a Product-Level Assessment}

The success of the regional trade agreement may depend crucially on the extent to which the core market, India, given its relative size, becomes more accessible to its periphery and vice versa. In this context, the prospects of increasing regional trade may depend more on the existence of product complementarities and export efficiencies (defined by comparative advantage) and other characteristics such as the degree of concentration and diversification of trade profiles amongst the regional partners, particularly between India and the other countries of the region. These are evaluated in detail in the following section. A useful beginning to the analysis is a review of trade structures at a broad level.

An analysis of product-level trade data, at the SITC heading level in Table 6 suggests that agriculture and primary materials have dominated intra-regional trade in South Asia for the past two decades. For example, in 1998 the percentage of regional exports that originated in food and live animals was over 60 percent for Pakistan, 41 percent for India, 35 percent for Sri Lanka, and 34 percent for Nepal. For Bangladesh, crude materials were its major regional exports, with a share of 60 percent of total exports. In contrast, South Asia's exports to the rest of the world are dominated by manufacturing products.

The data in Table 6 also reveal that, although food and live animals constitute a major share of regional exports, there have been large fluctuations over different periods. Such fluctuations are due to the import demand for basic food products such as rice, vegetables, fruits, pulses, onions, potatoes, and sugar, which vary with domestic supply conditions and, which, in turn, strongly impact the trade policies of respective member countries. The SACs often exercise arbitrary policies to maintain stable domestic prices in these "essential commodities." When shortfalls occur domestically imports are encouraged and when the domestic supply is stable, restrictions are re-imposed, explaining the large swings in export shares.

A further insight into product-level breakdown is necessary to highlight the nature and characteristics of regional and extra-regional trade patterns to capture the anomalies that may have had an 
impact on the formation of SAFTA. Table 6 provides several tabulations of the raw data. It shows the product-level breakdown of regional and extra-regional exports; their shares in total exports for 1998, and product shares in export growth between 1990 and 1998.

The country-level, disaggregated data in Annex Table A3 confirms the apparent skewness in intraregional trade discussed above. For example, India's regional exports in 1998 are dominated by rice, which accounts for 32 percent of the total. A single item, sugar, which constitutes almost 42 percent of its exports, dominates Pakistan's regional exports, similar to India's, ${ }^{12}$ and Bangladesh, similarly, records a 42 percent share from jute exports, while Sri Lankan intra-regional exports are much more diversified. Recent industrial diversification initiatives seem to have made a noteworthy change and Sri Lanka has moved away from exporting predominantly agricultural and primary products.

Nepal's regional exports are overwhelmingly in beans and pulses, with a share of 85 percent of its total regional exports in 1998. Despite a drop in the number of mainly agricultural products exported between 1990 and 1998, Nepal has succeeded in elevating certain manufactured products such as twine, ropes and cables, perfumes, cosmetics and toilet preparations, yarn, and leather, which were among its top 20 exports in 1998. These products were either insignificant or absent in the 1990 regional export mix. The easing of currency restrictions with India and cross-border investments likely impacted Nepal's regional exports in these product groups, 90 percent of which were exported to India.

\footnotetext{
12 Pakistan has undergone an acute loss of world market share both regionally and globally due to domestic structural difficulties in cotton production. The East Asian "economic crisis" dramatically depressed international prices for cotton and cotton-based products, which severely affected its competitiveness both within the region and beyond. Furthermore, Pakistan's cotton exports to the region were severely affected due to an import ban imposed in January 2000 by its major regional importer, India. Furthermore, launching of the FTA between India and Sri Lanka would tilt in favor of Indian cotton exports to Sri Lanka over Pakistan. This further epitomizes the complexity involved in efforts to enhance intra-regional trade based on comparative advantage.
} 
Table 6: Product Composition of South Asia's Intra-regional and Extra-regional Exports (1981-98)

\begin{tabular}{|c|c|c|c|c|c|c|c|c|c|c|c|c|c|c|c|c|c|c|c|c|}
\hline & \multicolumn{2}{|c|}{$\begin{array}{l}\text { Food \& Live } \\
\text { Animals }\end{array}$} & \multicolumn{2}{|c|}{$\begin{array}{c}\text { Beverages \& } \\
\text { Tobacco }\end{array}$} & \multicolumn{2}{|c|}{$\begin{array}{c}\text { Crude } \\
\text { Materials }\end{array}$} & \multicolumn{2}{|c|}{$\begin{array}{c}\text { Minerals \& } \\
\text { Fuels }\end{array}$} & \multicolumn{2}{|c|}{\begin{tabular}{|c|} 
Animal \& \\
Vegetable Fat
\end{tabular}} & \multicolumn{2}{|c|}{$\begin{array}{c}\text { Chemicals \& } \\
\text { Material }\end{array}$} & \multicolumn{2}{|c|}{$\begin{array}{l}\text { Manufacture } \\
\text { Goods }\end{array}$} & \multicolumn{2}{|c|}{$\begin{array}{c}\text { Machinery \& } \\
\text { Transport } \\
\text { Equipment }\end{array}$} & \multicolumn{2}{|c|}{\begin{tabular}{c|} 
Misc. \\
Manufactures
\end{tabular}} & \multicolumn{2}{|c|}{$\begin{array}{c}\text { Gold, } \\
\text { Ammunition } \\
\text { etc. }\end{array}$} \\
\hline & SA & ROW & SA & ROW & SA & ROW & SA & ROW & SA & ROW & SA & ROW & SA & ROW & SA & ROW & SA & ROW & SA & ROW \\
\hline \multicolumn{21}{|l|}{ India } \\
\hline 1981 & 10.2 & 26.6 & 0.9 & 3.4 & 7.2 & $\mid 10.1$ & 14.6 & 0.0 & 0.3 & 0.2 & 9.3 & 4.4 & 22.8 & 33.2 & $\mid 31.4$ & 7.6 & 3.0 & 14.2 & 0.2 & 0.2 \\
\hline 1990 & 11.0 & 14.0 & 1.5 & 0.8 & 8.3 & 9.8 & 0.9 & 2.9 & 0.0 & 0.3 & 7.7 & 7.4 & 40.9 & 37.4 & 26.0 & 7.4 & 2.6 & 18.3 & 0.9 & 1.6 \\
\hline 1995 & 21.5 & 15.7 & 1.0 & 0.9 & 3.7 & 5.1 & 1.5 & 1.1 & 0.1 & 0.5 & 11.3 & 9.8 & 41.2 & 38.6 & 15.7 & 8.0 & 2.5 & 18.4 & 1.6 & 1.9 \\
\hline 1998 & 41.1 & 15.0 & 0.6 & 0.6 & 2.4 & 4.1 & 2.0 & 0.4 & 0.1 & 0.5 & 11.1 & 9.3 & 25.3 & 38.5 & 13.3 & 6.9 & 2.6 & 22.3 & 1.5 & 2.4 \\
\hline \multicolumn{21}{|c|}{ Pakistan } \\
\hline 1995 & 20.6 & 8.8 & 0.0 & 0.1 & 25.3 & 10.9 & 0.2 & 1.3 & 0.0 & 0.0 & 1.6 & 0.4 & 48.5 & 54.7| & 1.8 & 0.3 & 1.6 & 23.2 & 0.3 & 0.2 \\
\hline 1997 & 33.9 & 11.5 & 0.0 & 0.1 & 9.5 & 4.3 & 2.1 & 1.0 & 0.0 & 0.0 & 3.4 & 0.7 & 45.7 & 56.4 & 1.7 & 0.2 & 2.6 & 25.7 & 1.1 & 0.3 \\
\hline 1998 & 63.2 & 13.2 & 0.0 & 0.1 & 4.9 & 2.3 & 0.1 & 0.3 & 0.0 & 0.1 & 1.8 & 0.7 & 26.3 & 54.0 & 1.4 & 0.4 & $\mid 1.7$ & 28.7 & 0.6 & 0.1 \\
\hline \multicolumn{21}{|c|}{ Bangladesh } \\
\hline 1981 & 43.8 & 15.4 & 0.0 & 0.3 & 24.7 & 16.5 & 0.0 & 0.0 & 0.0 & 0.0 & 6.7 & 0.6 & 23.1 & 64.9 & 0.2 & 0.6 & 0.3 & 1.1 & 1.3 & 0.7 \\
\hline 1990 & 27.4 & 14.2 & 0.6 & 0.1 & 44.2 & 6.8 & 0.6 & 1.3 & 0.0 & 0.0 & 16.4 & 1.1 & 9.1 & 33.9 & 0.6 & 0.9 & 0.6 & 41.6 & 0.3 & 0.1 \\
\hline 1998 & 29.0 & 7.1 & 0.0 & 0.1 & 59.6 & 1.7 & 0.5 & 0.2 & 0.0 & 0.0 & 24.7 & 0.9 & 7.9 & 11.4 & 2.2 & 1.1 & 1.7 & 77.4 & 0.1 & 0.2 \\
\hline \multicolumn{21}{|c|}{ Sri Lanka } \\
\hline 1981 & 65.2 & 45.0 & 0.2 & 0.4 & 16.2 & 19.0 & 14.6 & 14.2 & 1.2 & 1.1 & 0.3 & 0.5 & 1.2 & 3.6 & 0.3 & 0.5 & 0.8 & 15.7 & & 0.1 \\
\hline 1990 & 38.7 & 33.1 & 0.0 & 0.3 & 38.5 & 7.8 & 0.9 & 1.5 & 8.9 & 0.4 & 3.0 & 1.0 & 7.1 & 13.5 & 1.8 & 1.9 & 1.1 & 36.3 & 0.0 & 4.2 \\
\hline 1995 & 41.4 & 19.7 & 0.3 & 1.2 & 36.5 & 4.3 & 0.0 & 0.7 & 4.6 & 0.1 & 5.8 & 0.9 & 7.8 & 15.5 & 1.8 & 2.3 & 1.8 & 53.4 & 0.0 & 1.9 \\
\hline 1998 & 35.3 & 16.1 & 0.4 & 0.7 & 22.4 & 2.3 & 0.1 & 0.5 & 2.6 & 0.1 & 4.1 & 0.8 & 23.5 & 14.4 & 5.6 & 4.6 & 5.9 & 60.3 & & 0.3 \\
\hline \multicolumn{21}{|l|}{ Nepal } \\
\hline 1981 & 65.4 & 42.9 & 0.0 & 0.0 & 19.6 & \begin{tabular}{|l|}
18.7 \\
\end{tabular} & 0.0 & 0.0 & 3.7 & 2.2 & 5.7 & 3.4 & 5.3 & 25.9 & 0.0 & 2.0 & 0.1 & 3.8 & 0.2 & 1.2 \\
\hline 1990 & 62.0 & 11.3 & 0.1 & 0.3 & 24.9 & 4.0 & 0.0 & 0.0 & 1.9 & 0.8 & 2.0 & 0.5 & 7.5 & 51.8 & 0.0 & 0.0 & 1.7 & 31.0 & 0.0 & 0.3 \\
\hline 1998 & 34.2 & 3.0 & 0.0 & 0.0 & 0.2 & 1.0 & 0.0 & 0.0 & 0.0 & 0.0 & 0.0 & 0.0 & 0.1 & 53.6 & 0.1 & 0.2 & 0.2 & 39.0 & 65.0 & 3.4 \\
\hline \multicolumn{21}{|c|}{ Bhutan } \\
\hline 1981 & 0.0 & 72.7 & 0.0 & 0.0 & 0.0 & 0.9 & 6.4 & 0.3 & 38.9 & 1.7 & 37.3 & 4.0 & 16.3 & 3.3 & 1.1 & 4.5 & 0.0 & 85.2 & 0.0 & 0.0 \\
\hline 1995 & 15.7 & 20.4 & 7.5 & 9.7 & 11.2 & 14.5 & 25.7 & 33.3 & 0.0 & 0.0 & 20.4 & 26.5 & 18.9 & 24.4 & 0.0 & 0.0 & 0.5 & 1.2 & 0.0 & 0.0 \\
\hline 1998 & 28.3 & 3.8 & 1.5 & 0.0 & 6.5 & 9.9 & 4.5 & 37.1 & 0.0 & 0.0 & 5.3 & 1.2 & 53.2 & 17.7 & 0.6 & 15.1 & 0.0 & 14.9 & 0.0 & 0.3 \\
\hline
\end{tabular}

Source: Based on WITS database, World Bank

$\boldsymbol{S A}=$ Intra-Regional South Asia Trade; $\boldsymbol{R} \boldsymbol{O W}=$ Rest of the World. The product classifications are based on SITC 2-digit heading (Rev. 2). Food and Live Animals includes meat and meat

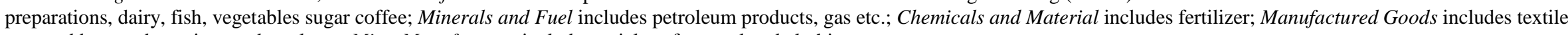
yarn, rubber products, iron and steel etc.; Misc. Manufactures includes articles of apparel and clothing. 
India and Pakistan are the only countries that have succeeded in exporting a noteworthy share of manufacturing products to the region. India in particular displays a higher regional orientation for manufactured products spanning a broad array of product groups. India's leading regional manufactured exports during this period included motor vehicles, cotton yarn, medicines, textiles, and apparel.

The comparatively high intra-regional trade ratios for manufactured goods displayed by India suggest that it has developed "appropriate technology" (i.e. technology that meets basic functional features but are comparatively low cost) to meet demand in the region as substitutes for products from industrial countries. The ascendance of certain manufactured exports differentiated between what used to be the industrial countries' domain such as automobiles, pharmaceuticals, and agricultural implements. These highly segmented industrial products accounted for 36 percent of India's regional exports, compared with 7 percent of its exports to the rest of the world. ${ }^{13}$ This development illustrates the segmentation of India's evolving "comparative advantage, ${ }^{14}$ i.e. its ability to fulfill, to a certain extent, the region's demand for manufactured goods, a characteristic that the other countries have not sufficiently demonstrated.

In summary, the region has established a mutual dependency in basic foods and agricultural products, although they are not fully liberalized. A narrow group of products on which most countries display comparative advantage has made inroads in regional trade and are mostly made up of agriculture and raw material for manufacture. The exception is India. The extent to which Bangladesh, Nepal, and Sri Lanka initiated trade policy reforms resulted in sizable increases in imports from India both in agriculture and manufacture. They helped India expand as well as diversify its exports to the region during the period 199098.

\section{Box 1: The Impact of Trade Reforms}

Trade reforms in fact helped South Asia to increase regional and extra-regional trade between 1990 and $1998 .^{\mathrm{B} 1}$ The reforms reduced the levels of protection, but stimulated only a moderate shift in the product

\footnotetext{
${ }^{13}$ Comparison based on SITC 4-digit exports.

${ }^{14}$ A further interesting observation is that India seems to be acquiring market share particularly in other developing countries beyond the South Asia region for this group of manufacturing products, conceivably emerging from typical demand attributes to suit those in the region.
} 
mix exported by the South Asian countries to the region, with the exception of India. India's regional exports increased both vertically (in value) and horizontally (in the number of product categories); see Annex Figure A1. India displayed an increasingly diversified export basket to the region, for which it increased its range of products by 33 percent between 1990 and 1998. Bangladesh, Pakistan, and Sri Lanka all had moderate to insignificant changes in their export baskets.

Certain regional exports among SACs dropped out during the mid-1990s owing to either supply-side weaknesses or increased competition from East Asian countries. Nepal has undergone a unique change in regional trade compared with the other members in the region. Annex Figure A1 provides a graphical view of changes in product clusters in three broad sectors: agriculture, crude material, i.e. jute, rubber, and manufactured goods. Nepal's export basket to the region shrank considerably between 1990 and 1998, with a 60 percent reduction in the range of goods exported to the region. The raw data and Figure A1 demonstrate a critical feature: the increase in exports since reforms in the early 1990s has more or less occurred within the existing range of products for most SACs. In the case of Nepal, the expansion has been in a significantly smaller range of products compared with 1990.

${ }^{\text {B1 }}$ Pitigala et al. (2001).

In contrast, manufactured goods dominate South Asia's extra-regional exports. India's manufacturing exports are much more dispersed than those of the other South Asian countries. Cut diamonds, jewelry, cotton yarn, textiles, and leather products and their sub-categories are prominent Indian exports. Pakistan's exports to the rest of the world are dominated by raw cotton and cotton-based products, representing an estimated 67 percent of its exports. Where Bangladesh and Sri Lanka are concerned the overwhelming global orientation is in textiles and apparel. For example, a staggering 75 percent of Bangladesh's global exports consist of apparel, which experienced a fivefold increase from 1990 to 1998. Meanwhile, Sri Lanka's exports in apparel constitute a share of 50 percent of the total in 1998. However, tea continues to be Sri Lanka's highest single export; the country recently emerged as the world's largest exporter in tea. 


\section{Implications of the Divergence and Concentration of Export Structures}

It appears from the above that there are several inconsistencies in the region's trade patterns that need further examination. First, there appears to be a significant divergence ${ }^{15}$ between products that are exported to the region and to the rest of the world. While primary products dominate intra-regional trade, manufactured products dominate exports to the rest of the world. India is the only exception, having achieved some symmetry in exports with the region and the rest of the world. This is mainly a consequence of the restrictive trade regimes particularly in India, Bangladesh and Pakistan despite measures to reduce them in recent years. ${ }^{16}$ Another explanation appears to be India's growing efficiency in a range of agriculture as well as manufactured products (discussed further, below). The ability to increase regional exports is contingent on the degree to which dynamic exports ${ }^{17}$ are incorporated in the regional export mix.

Secondly, the exports of most member countries (with the exception of India) seem to be confined to a few products, that is, a small number of products seem to accumulate a significant share of exports revenues. The likely success or failure of any proposed regional trade arrangement is contingent on the range of products prospective members have the capacity to export or import. If the members export a wide range of diversified goods, this is a positive factor. If their exports are concentrated, it will limit the prospects of increasing regional trade. ${ }^{18}$

Table 7 presents a summary of the divergence and concentration estimates to further examine the two propositions, above. The summary is derived from raw data in annex Table A3. The data are for products that

\footnotetext{
${ }^{15}$ Divergence is defined as the departure of intra-regional exports from extra-regional exports in major product categories.

${ }^{16}$ See Pigato et. al and Pitigala et al (2001) for more details on trade reforms in South Asia in the 1990's.

${ }^{17}$ Dynamic exports are defined as those growing higher than the average.

18 "The underlying assumption is that the higher the level of export diversification, the better the prospects for a successful regional initiative. The more diversified a country's exports the greater the range of potential products that can be traded with regional partners. If only a limited number of such goods exist, members of an RTA may have to rely heavily on third countries for a higher share of its key imports (and as a destination for their major exports), and this would be likely to reduce their commitment to and perceived benefits from the arrangement" (Yeats, 1998).
} 
accounted for 75 percent of the growth in exports destined to the region and to the rest of the world between 1990 and $1998 .^{19}$

The data suggest that Pakistan and India have experienced limited consistency in terms their dynamic exports to the rest of the world also being exported to the region. Evidence from all other SACs shows weaker coherence. The disparity is extreme for Bangladesh and Nepal. For example, not a single product that accounted for 75 percent of Nepal's growth in exports to the rest of the world is represented in the growth of its regional exports; whilst, in case of Bangladesh, only 1 percent of those goods exported to ROW are represented in intra-regional trade. The extent to which the relative share of regional trade can be increased depends on the extent to which countries' dynamic exports are represented in regional trade. In this context prospects for greater regional exports for Bangladesh, Nepal, and Sri Lanka, in particular, do not appear to be encouraging. The increase in intra-regional trade in recent years, as spectacular as it may seem, materialized within the existing exports that are not among these countries' dynamic segments.

A relatively high level of concentration in exports for Nepal confirms that the country has a narrow export base compared with the other countries. For example, the raw data in annex Table A3 show that two products at the SITC 4-digit category accounted for 75 percent of Nepal's export growth to the ROW. Export growth of Bangladesh and Pakistan too are relatively concentrated. Sri Lanka export growth is more diversified. India, in contrast, compares well with newly industrial countries; its greater dispersion of exports confirms its broad export structure.

Table 7: Divergence and Concentration Summary

\begin{tabular}{|l|c|c|c|c|c|}
\hline & India & Pakistan & Bangladesh & Sri Lanka & Nepal \\
\hline $\begin{array}{l}\text { Divergence of Exports - Regional exports } \\
\text { that match exports to the ROW as a } \\
\text { share of the latter * }\end{array}$ & $18 \%$ & $22 \%$ & $1 \%$ & $10 \%$ & $0 \%$ \\
\hline
\end{tabular}

\footnotetext{
${ }^{19}$ The products ranked on growth levels are chosen as they better reflect the dynamic products than mere trade values. The cut-off point of 75 percent was chosen to exclude marginal products that may not be reported regularly. The SITC 4digit product classification is the highest level of disaggregation for which the comparisons can be carried out because consistent reporting of data is inaccessible at further disaggregated levels, such as the SITC or Harmonized 6 to 8-digit level.
} 


\begin{tabular}{|l|c|c|c|c|c|}
\hline $\begin{array}{l}\text { Concentration of Exports - Number of } \\
\text { products accounting for 75\% of export } \\
\text { growth to the ROW (Annex Table 3) ** }\end{array}$ & 47 & 11 & 7 & 22 & 2 \\
\hline $\begin{array}{l}\text { Share of Textile and Apparel in total } \\
\text { exports }\end{array}$ & 28.2 & 72.8 & 82.7 & 52.1 & 60.1 \\
\hline
\end{tabular}

Notes: * Products shown in each country's regional exports that match exports to the ROW that were among its dynamic exports (products which accounted for 75 percent of total export growth between 1990-1998). The share for Nepal must be treated with caution, as a large share of its regional exports were reported under SITC 9310 (miscellaneous category), and therefore do not fully reflect the extent of "divergence".

** Export growth between 1990 and 1998. Out of a possible 1252 products (using the number of products exported by U.S. in 1998 as a benchmark) reported under the SITC 4-digit level.

\# Based on authors calculations for year 1998.

Central to the concentration of exports by Bangladesh, Nepal, Pakistan, and to some extent Sri Lanka is the dominance of textiles and apparel. Over 85 percent of Bangladesh's exports are concentrated in textiles and apparel. Textile and apparel bias is not too different for Nepal, Pakistan, and Sri Lanka, where its dominance ranges from 60 to 70 percent. The textiles and apparel sector is heavily protected in most countries. Although Sri Lanka has drastically reduced the level of protection in the sector, most other countries in the region have been somewhat reluctant to undertake sweeping reforms. Furthermore, India maintains a vehement opposition to the inclusion of textiles and apparel under SAPTA, although tariff rate quotas were allowed to a limited extent under the India-Sri Lanka bilateral trade agreement.

In sum, divergence and concentration data on the part of Bangladesh, Nepal, and Sri Lanka, and to some extent Pakistan, do not auger well for a rapid increase in regional trade. The prospects of increased regional exports, contingent upon the degree to which dynamic exports are incorporated in the regional export mix, do not appear to be the case in South Asia. The divergence can be discerned from the underlying shift of South Asia's trade, which has undergone a greater orientation toward unskilled and semi-skilled manufacturing products for which the SACs appear to compete with each other in third markets.

Furthermore, the heavy bias demonstrated by the concentration of exports may complicate prospects for increasing regional trade. Except for India, most countries in the region export a narrow range of goods, dominated by textiles and apparel. Reforms that have helped reduce the general level of protection have nevertheless retained a relatively high level of protection for textiles, apparel, and certain manufacturing products. Furthermore, SAARC members other than India have the capacity to export a limited range of products. Unless the export base undergoes a substantial diversification that complements the imports of 
regional members, prospects for increasing regional trade may be limited. The current resistance to the further liberalizing of such products will limit the prospects of increasing regional trade in the near future. Moreover, the value added criteria under SAPTA rules of origin remain an effective deterrent for countries such as Sri Lanka to exploit any preferences that may be accorded under an FTA. ${ }^{20}$ The SACs also need to be wary of increasing competition that will emerge from phasing out the MFA. Empirical evidence suggests that South Asia overall will gain from the abolition of the MFA, but with results differing by country. ${ }^{21}$

\section{Are there Complementarities among the South Asian Countries?}

A further question that periodically emerges in the subject of regional trade is whether the products that member countries export (or have the capacity to export) match the countries' imports from their regional partners. The import requirements of South Asian countries vary based on country size and the level of industrial development. The requirements will continue to evolve as the countries ascend the ladder of economic development and industrialization. India, the region's dominant economy, has a relatively lower ratio of imports to GDP consistent with its larger size, yet the country has a broad array of import needs compared with a country such as Bhutan, which has far narrower and limited imports despite its large trade to GDP ratio. If the type of goods some South Asian countries export coincides with the imports of the others, this should facilitate the regional trade arrangement. If not, it would negatively impact the RTA. ${ }^{22}$ The issue of complementarity emerges as one of the important elements the empirical literature proposes, including the validity of the "natural trading partner" hypothesis.

It would be useful to have an assessment of complementarity that incorporates current imports and exports as well as potential imports and exports. Such analysis is beyond the scope of the current study. Therefore, the analysis must be based on actual trade flows, which to a large extent provide an indication of the realm of prospective trade. The test of complementarity needs to be evaluated on two fronts. First, as implied above, major import requirements of members must be "matched" with what their regional partners

\footnotetext{
${ }^{20}$ Pitigala, (1998).

21 Kathuria, Martin and Bharadwaj (2000).

${ }^{22}$ Yeats (1998).
} 
export. Having "matching" products is just one aspect of fulfilling the test of complementarity. Exports that match the import needs of member countries must be relatively efficient so that potential costs from trade diversion are avoided. The central characteristics of international trade based on efficiency are governed by the concept of comparative advantage and specialization. Countries with different comparative advantages and product specializations should have more mutually beneficial trade opportunities than those where a high degree of similarity exists. If there is little difference in the degree of comparative advantage and specialization between countries, and in sectors where aggregate trade is relatively low, this would not favor the eventual success of the trade agreement. One useful measure of specialization, widely used for policyrelated studies is the International Revealed Comparative Advantage (IRCA) Index. The IRCA index compares a given country's export structure to the world export structure. The IRCA index is defined as:

(2) $I R C A_{i j}=\frac{X_{i j} / X_{w j}}{\sum X_{i j} / \sum X_{w j}}$

where $I R C A_{i j}$ is the index of revealed comparative advantage of country $i$ in commodity $j ; X_{i j}$ is country $i$ 's export of commodity $j ; X_{w j}$ is world exports of commodity $j ; \Sigma X_{i}$ is total exports of country $i$; and $\Sigma X_{w}$ is total world exports. The RCA of country $i$ for product $j$ is measured by the product share in the country's exports relative to the share in world trade. For products in which the index is unity or greater, the country is deemed to have a comparative advantage; for products in which the index is less than unity, it may be determined that the country does not have a comparative advantage. ${ }^{23}$

It is important to note, however, that the RCA index, as a measure of comparative advantage, does not discriminate between "inherent" comparative advantage and policy-induced comparative advantages. Any attempt to apply the concept of RCA to South Asian countries must therefore acknowledge the influence of distortions created by their policy regimes. As demonstrated by Pitigala et al. (2001), while trade barriers have been progressively reduced throughout South Asia, some significant barriers remain through the late 1990s,

\footnotetext{
${ }^{23}$ The RCA index as defined in equation 2, developed by Balassa (1965), has been employed by a number of policy related studies, including Yeats (1996) and Michealy (1995).
} 
particularly in the case of India. Consequently, the true or "inherent" comparative advantage of South Asian countries may somewhat, are different than the following empirical results suggest. ${ }^{24}$

Table 8 provides, for each of the South Asian countries, their import structure ${ }^{25}$ and the corresponding RCAs of South Asian partners. A review of complementarity by each SAC's major imports and partner's comparative advantage does not seem encouraging for the potential success of the FTA. For example, India, the major market in the region, shows that its major imports can be identified mostly in semi-manufacturing (which is a consequence of its import policies) for which the rest of the region largely shows neither the capacity nor comparative advantage. This is reflected in the meager share of imports from the regional members on each item and the corresponding RCAs. India's sugar imports (SITC 0612) reported a substantial (70 percent) share of its total imports from the region. However, sugar represents a mere 0.4 percent of India's global imports. The prospects of the rest of the SACs substantially increasing their current low share of exports to India seems less promising based on their current trade structures. However, with sufficient reduction in India's existing trade barriers - the new incentives bringing about an adjustment of resources among competing industries between India and its neighbors, enhancing current, as well as new capacities, its neighbors could make progress. In the meantime, prospects that may exist are confined to what are often termed "niche" markets (identified at HS 6-disaggregated level), which are unlikely to have a substantial impact on transforming their meager export shares with India unless quality and product features are compatible with those imported from elsewhere by India.

The statistics of the second largest economy, Pakistan, suggest a similar scenario. The region, which barely accounts for 2 percent share of Pakistan's imports, overall demonstrates a negligible capacity to fulfill its import needs. The RCA indices show prospects that a limited portion of Pakistan's import requirements

\footnotetext{
${ }^{24}$ Ideally, comparative advantage should be measured in an environment in which neither external trade constraints (like tariff and non-tariff barriers, or preferential access to export markets) distort an individual country's "real" export structure, or where domestic market interventions (such as subsidies) in the exporting country have sector-specific effects or a general anti-export bias.

${ }^{25}$ The major 50 imports at SITC 4-digit level represent between 66 and 96 percent of total imports of South Asian countries. The product mix in 1998 is largely representative of latter 1990s. Readers must also note that the product differentiation within each of the SITC 4-digit classification (identified at Harmonized Classification 6-digit level) may provide part of an explanation for the apparent discrepancy between similar products that have successful global exports, but have no effectual intra-regional trade.
} 
can be met by India, but are not reflected in formal export statistics due to the existing relationship with India. $^{26}$ Instead products, including textiles, machinery, apparel and foods, that fall under existing import restrictions are reflected in informal channels. ${ }^{27}$

Bangladesh and Sri Lanka provide something of an exception to the above. Based on the complementarity of its imports and partner RCA indices, with products accounting for 37 percent of Bangladesh's and 34 percent of Sri Lanka's imports, the region appears to be an efficient supplier. Although a notable share is imported from India and Pakistan, it is nevertheless evident that a major share of the manufactured products (textile and other) essential for both Bangladesh's and Sri Lanka's export-oriented industries continues to originate from beyond the region. Similarly, a broad array of capital goods and raw material essential for their industrial development are imported from elsewhere.

In summary, only four of the 50 major products imported by Bangladesh have a regional import share of over 30 percent (in value), while nine of the major 50 imports of Sri Lanka show a regional import share of over 30 percent. On those occasions when the region, including India and Pakistan, has not been able to transfer its revealed comparative advantage to successfully export to Sri Lanka and Bangladesh, the reason may lie in the quality differentiation that Sri Lanka's export destinations demand. This implies that for a majority of its manufacturing needs, unless there is an adjustment of quality, Sri Lanka and Bangladesh may continue to rely heavily on sources beyond the region. Conversely, having demonstrated comparative advantages in products of interest to Sri Lanka and Bangladesh, the incentive that exists for India and Pakistan must be interpreted positively in terms of prospects of further trade between these members.

\footnotetext{
${ }^{26}$ Note that Pakistan maintains a restricted list of imports from India, which currently stands at 615 products, identified at the HS 6-digit level.

${ }^{27}$ See Pohit et al (2000).
} 
Table 8: Major Imports of SACs and Respective RCA Indices of Partner Countries (1998)

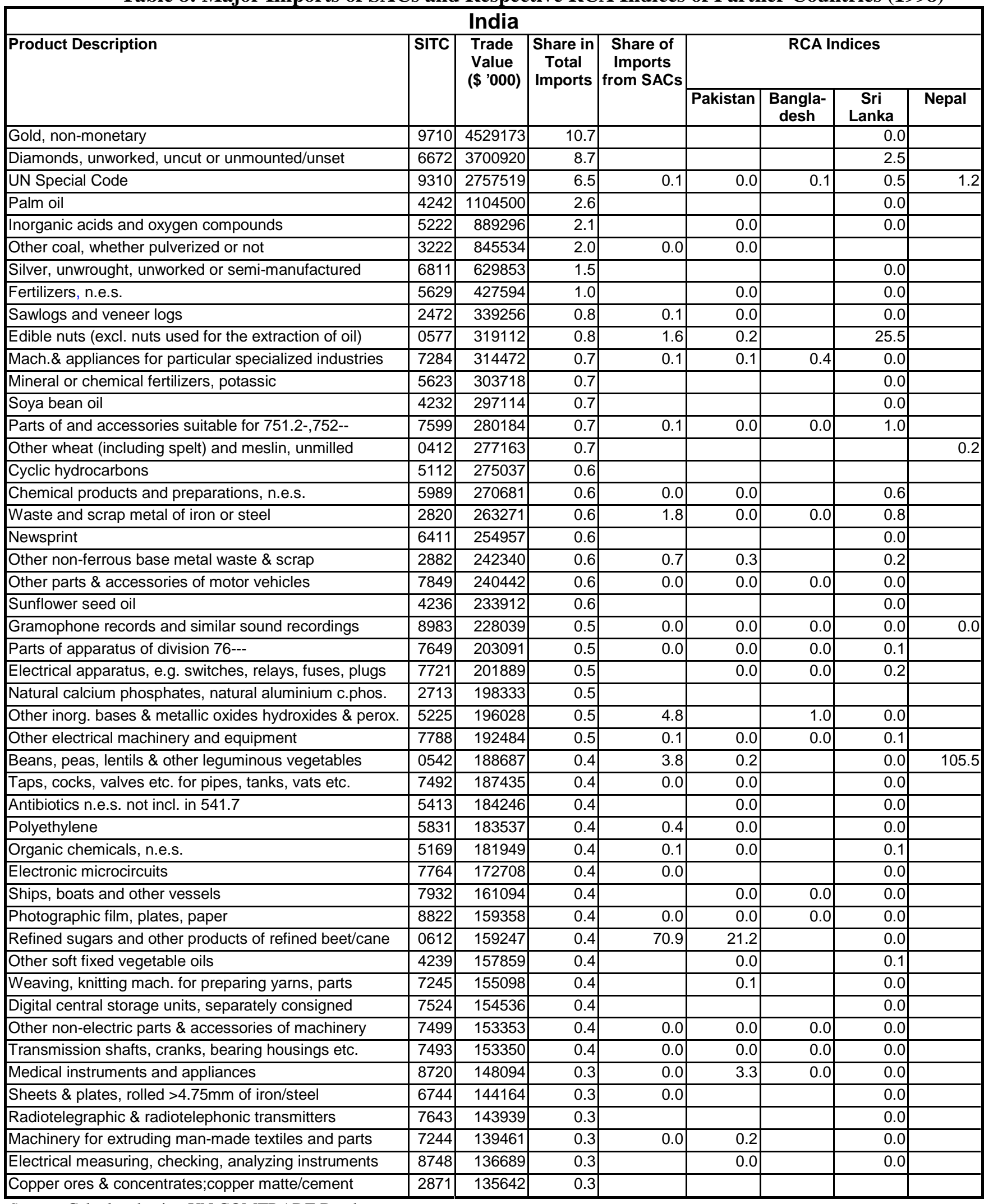

Source: Calculated using UN COMTRADE Database

Notes: A value of 0.0 represents less than US $\$ 100$ in exports; blanks represent zero exports. 


\begin{tabular}{|c|c|c|c|c|c|c|c|c|}
\hline \multicolumn{9}{|c|}{ Pakistan } \\
\hline \multirow[t]{2}{*}{ Product Description } & \multirow[t]{2}{*}{ SITC } & \multirow{2}{*}{$\begin{array}{l}\text { Trade } \\
\text { Value } \\
(\$>00)\end{array}$} & \multirow{2}{*}{$\begin{array}{l}\text { Share in } \\
\text { Total } \\
\text { Imports }\end{array}$} & \multirow{2}{*}{\begin{tabular}{|c|} 
Share of \\
Imports from \\
SACs
\end{tabular}} & \multicolumn{4}{|c|}{ RCA Indices } \\
\hline & & & & & India & $\begin{array}{c}\text { Bangla- } \\
\text { desh }\end{array}$ & Sri Lanka & Nepal \\
\hline Palm oil & 4242 & 726778 & 9.2 & 0.0 & 0.0 & & 0.0 & \\
\hline Durum wheat, unmilled & 0411 & 356516 & 4.5 & 0.0 & 0.0 & & & \\
\hline Tea & 0741 & 246598 & 3.1 & 10.4 & 34.6 & 0.0 & 305.6 & \\
\hline Gold, non-monetary & 9710 & 203606 & 2.6 & 0.0 & & & 0.0 & \\
\hline Fertilizers, n.e.s. & 5629 & 200448 & 2.5 & 0.0 & 0.0 & & 0.0 & \\
\hline Soya bean oil & 4232 & 174441 & 2.2 & 0.0 & 0.0 & & 0.0 & \\
\hline Passenger motor cars and for transport & 7810 & 160903 & 2.0 & 0.1 & 0.1 & 0.0 & 0.0 & \\
\hline Polycarboxylic acids \& their anhydrides etc. & 5138 & 147012 & 1.9 & 1.4 & 1.3 & & 0.0 & \\
\hline Medicaments(including veterinary) & 5417 & 129158 & 1.6 & 1.2 & 1.6 & 0.0 & 0.0 & \\
\hline Other sheets and plates of iron or steel & 6749 & 117869 & 1.5 & 0.8 & 0.5 & & 0.0 & \\
\hline Cotton, not carded or combed & 2631 & 117173 & 1.5 & 0.0 & 1.2 & 0.0 & 0.0 & \\
\hline Mach.\& appliances for specialized ind. & 7284 & 108260 & 1.4 & 0.0 & 0.3 & 0.0 & 0.0 & 0.0 \\
\hline Weaving, knitting mach. for preparing yarns & 7245 & 105059 & 1.3 & 0.0 & 0.4 & & 0.0 & \\
\hline Chemical products and preparations, n.e.s. & 5989 & 103799 & 1.3 & 0.4 & 0.5 & & 0.6 & \\
\hline Acyclic alcohols \& their hal. derivatives & 5121 & 96812 & 1.2 & 0.1 & 0.7 & 0.0 & 0.3 & \\
\hline Parts of apparatus of division 76--- & 7649 & 91209 & 1.1 & 0.1 & 0.0 & 0.0 & 0.1 & \\
\hline Ships, boats and vessels for breaking up & 7933 & 81236 & 1.0 & 9.1 & 1.2 & & 0.1 & \\
\hline Synthetic organic dyestuffs & 5311 & 80214 & 1.0 & 14.6 & 5.9 & & 0.0 & 1.5 \\
\hline Mach. for extruding man-made textiles \& parts & 7244 & 76747 & 1.0 & 0.1 & 1.0 & & 0.0 & \\
\hline Polyethylene & 5831 & 76432 & 1.0 & 0.1 & 0.1 & & 0.0 & \\
\hline Parts of heading 792--,excl. tyres, engines & 7929 & 69054 & 0.9 & 0.0 & 0.1 & & 0.0 & \\
\hline Other nitrogen-function compounds & 5148 & 67117 & 0.8 & 3.4 & 0.2 & & 0.0 & \\
\hline Beans, peas, lentils \& other vegetables & 0542 & 66437 & 0.8 & 7.0 & 3.5 & & 0.0 & \\
\hline Antibiotics n.e.s., not incl. in 541.7 & 5413 & 66397 & 0.8 & 4.2 & 3.2 & & 0.0 & \\
\hline Insecticides packed for sale etc. & 5911 & 65475 & 0.8 & 0.1 & 10.2 & 0.0 & 0.1 & \\
\hline Polypropylene & 5832 & 63099 & 0.8 & 3.6 & 0.2 & & 0.0 & \\
\hline Parts of the engines \& motors of 714 & 7149 & 61682 & 0.8 & 0.0 & 0.0 & 0.0 & 0.0 & \\
\hline Electrical motors \& generators, generating sets & 7162 & 55570 & 0.7 & 0.0 & 0.2 & 0.0 & 0.0 & \\
\hline Other coal, whether or not pulverized & 3222 & 54067 & 0.7 & 0.0 & 0.3 & & & \\
\hline Polyvinyl chloride & 5834 & 53931 & 0.7 & 0.1 & 0.2 & 0.0 & 0.0 & \\
\hline Regenerated fibers suitable for spinning & 2671 & 53801 & 0.7 & 2.0 & 0.2 & & 0.0 & \\
\hline Motor vehicles for transport of goods/ & 7821 & 52159 & 0.7 & 0.0 & 0.1 & 0.0 & 0.0 & \\
\hline Machine plant \& similar lab. equipment & 7416 & 51664 & 0.7 & 0.0 & 0.2 & 0.0 & 0.0 & \\
\hline Wheeled tractors, not incl. in 744.11/783.2- & 7224 & 48822 & 0.6 & 0.0 & 0.2 & & 0.0 & \\
\hline Synthetic fibers not carded, combed & 2665 & 44951 & 0.6 & 1.3 & 0.6 & & 0.0 & \\
\hline Structures \& parts of structures; iron/steel; plates & 6911 & 44616 & 0.6 & 0.0 & 1.3 & & 0.0 & 0.0 \\
\hline Electrical app. (switches, relays, fuses, plugs etc.) & 7721 & 44611 & 0.6 & 0.0 & 0.2 & 0.0 & 0.2 & \\
\hline Mineral or chemical fertilizers, nitrogenous & 5621 & 44419 & 0.6 & 0.0 & 0.1 & 0.0 & 0.0 & \\
\hline Tinned sheets and plates, of steel & 6747 & 43542 & 0.5 & 0.9 & 4.9 & & 0.1 & \\
\hline Other parts \& accessories of motor vehicles & 7849 & 43273 & 0.5 & 0.1 & 0.2 & 0.0 & 0.0 & 105.5 \\
\hline Cyclic hydrocarbons & 5112 & 42935 & 0.5 & 0.3 & 0.1 & & & \\
\hline Parts of and accessories suitable for 751.2- & 7599 & 42698 & 0.5 & 0.1 & 0.1 & 0.0 & 1.0 & \\
\hline Other tyres, tyre cases, inner tubes & 6259 & 40622 & 0.5 & 7.8 & 1.1 & & 18.2 & \\
\hline Engines \& motors, such as water turbines etc. & 7188 & 40298 & 0.5 & 0.0 & 0.1 & & 0.0 & \\
\hline Iron ore agglomerates (sinters, pellets etc) & 2816 & 40079 & 0.5 & 37.4 & 2.2 & & & \\
\hline Other non-electric parts \& accessories of machines & 7499 & 13017 & 0.2 & 1.8 & 0.5 & 0.0 & 0.0 & \\
\hline
\end{tabular}

Source: Calculated using UN COMTRADE Database

Notes: A value of 0.0 represents less than US $\$ 100$ in exports; blanks represent zero exports.. 


\begin{tabular}{|c|c|c|c|c|c|c|c|c|}
\hline \multicolumn{9}{|c|}{ Bangladesh } \\
\hline \multirow[t]{2}{*}{ Product Description } & \multirow[t]{2}{*}{ SITC } & \multirow{2}{*}{$\begin{array}{c}\text { Total } \\
\text { Imports } \\
\left(\${ }^{\prime} 000\right)\end{array}$} & \multirow{2}{*}{$\begin{array}{l}\text { Share of } \\
\text { Imports }\end{array}$} & \multirow{2}{*}{\begin{tabular}{|c|} 
Share of \\
Imports \\
from \\
SACs
\end{tabular}} & \multicolumn{4}{|c|}{ RCA Indices } \\
\hline & & & & & India & Pakistan & Sri Lanka & Nepal \\
\hline Cotton fabrics, woven, bleached, dyed, printed & 6522 & 412120 & 6.0 & 18.8 & 5.3 & 28.6 & 1.3 & 0.1 \\
\hline Sheets \& plates, rolled; thickness of $<3 \mathrm{~mm}$. & 6746 & 279166 & 4.1 & 9.5 & 0.1 & 0.0 & 0.0 & \\
\hline Portland cement,ciment fondu,slag cement. & 6612 & 240975 & 3.5 & 28.0 & 1.3 & 0.3 & 0.0 & \\
\hline Cotton not carded or combed & 2631 & 236638 & 3.5 & 13.0 & 1.2 & 6.1 & 0.0 & \\
\hline Gas oils & 3343 & 234729 & 3.4 & 0.0 & 0.0 & & & \\
\hline Cotton yarn & 6513 & 219585 & 3.2 & 97.0 & 24.9 & 92.6 & 1.6 & \\
\hline Rice semi-milled or wholly milled, & 0422 & 202754 & 3.0 & 98.3 & 31.7 & 47.7 & 0.1 & 8.3 \\
\hline Ships, boats and other vessels for breaking up & 7933 & 193570 & 2.8 & 0.0 & 1.2 & & 0.1 & \\
\hline Fabrics, woven of synthetic textile materials & 6531 & 185025 & 2.7 & 0.9 & 1.9 & 24.0 & 0.4 & \\
\hline Petroleum oils \& crude oils .from bitumin. minerals & 3330 & 177017 & 2.6 & 0.0 & 0.0 & 0.2 & & \\
\hline Fabrics, woven, of synthetic fibers & 6534 & 171556 & 2.5 & 0.8 & 3.5 & 0.0 & 0.5 & \\
\hline Other wheat and meslin, unmilled & 0412 & 142350 & 2.1 & 1.0 & 0.0 & & 0.3 & 0.4 \\
\hline Yarn of discontinued synthetic fibers, contain $<85 \%$ & 6516 & 138184 & 2.0 & 6.6 & 5.3 & 6.0 & 1.7 & \\
\hline Soya bean oil & 4232 & 125396 & 1.8 & 0.0 & 0.0 & & 0.0 & \\
\hline Metal cutting machine-tools & 7361 & 117912 & 1.7 & 2.0 & 0.3 & 0.0 & 0.0 & \\
\hline Knitted/crocheted fabrics of fibers & 6552 & 94234 & 1.4 & 14.3 & 0.4 & 4.1 & 1.4 & \\
\hline Palm oil & 4242 & 90050 & 1.3 & 0.0 & 0.0 & & 0.0 & \\
\hline Cotton fabrics, woven, unbleached, & 6521 & 76832 & 1.1 & 18.1 & 16.4 & 70.9 & 5.3 & \\
\hline Raw silk (not thrown) & 2613 & 65092 & 1.0 & 0.3 & 0.5 & & & \\
\hline Passenger motor cars \& goods transport & 7810 & 64038 & 0.9 & 1.0 & 0.1 & 0.0 & 0.0 & \\
\hline Fabrics, woven containing $85 \%$ of synthetic fibers & 6532 & 63701 & 0.9 & 0.6 & 2.1 & 0.0 & 6.0 & \\
\hline Beans, peas, lentils \& other vegetables & 0542 & 59204 & 0.9 & 15.7 & 3.5 & 0.2 & 0.0 & 211.1 \\
\hline Kerosene and other medium oils & 3342 & 58514 & 0.9 & 1.6 & 0.0 & & & \\
\hline Rape and colza seeds & 2226 & 57542 & 0.8 & 0.0 & 0.0 & & & \\
\hline Milk \& cream, preserved, concentrated or sweetened & 0224 & 57323 & 0.8 & 4.9 & 0.0 & 0.1 & 0.0 & \\
\hline Mach.\& appliances for specialized industries & 7284 & 55884 & 0.8 & 8.4 & 0.3 & 0.1 & 0.0 & \\
\hline Shirts, men's, of textile fabrics & 8441 & 55269 & 0.8 & 0.3 & 10.0 & 7.4 & 15.4 & 138.3 \\
\hline Radiotelegraphic \& radiotelephonic transmitters & 7643 & 48922 & 0.7 & 0.1 & 0.0 & & 0.0 & \\
\hline Machinery for extruding man-made textiles & 7244 & 48309 & 0.7 & 18.6 & 1.0 & 0.2 & 0.0 & \\
\hline Yarn contain.85\% by weight of synthetic fibers & 6514 & 47564 & 0.7 & 11.5 & 0.9 & 2.7 & $\overline{0.6}$ & $\overline{0.0}$ \\
\hline Small-wares and toilet articles etc. & 8998 & 47475 & 0.7 & 0.2 & 0.4 & 0.0 & 0.2 & 1.5 \\
\hline Rice in the husk or husked, & 0421 & 43399 & 0.6 & 91.1 & 0.0 & & & \\
\hline Sugars, beet and cane, raw, solid & 0611 & 42381 & 0.6 & 0.0 & 0.1 & 0.0 & 0.0 & \\
\hline Parts of the machine-tools of 736-- & 7369 & 40741 & 0.6 & 0.0 & 0.8 & 0.0 & 0.0 & \\
\hline Newsprint & 6411 & 38390 & 0.6 & 0.2 & 0.0 & & 0.0 & \\
\hline Zinc and zinc alloys, unwrought & 6861 & 37440 & 0.5 & 0.8 & 0.2 & 0.0 & & \\
\hline Electrical motors \& generators, generating sets & 7162 & 37313 & 0.5 & 1.3 & 0.2 & 0.0 & 0.0 & \\
\hline Mineral or chemical fertilizers, nitrogenous & 5621 & 37272 & 0.5 & 27.5 & 0.1 & & 0.0 & \\
\hline Sewing machines, furniture for & 7243 & 34927 & 0.5 & 0.5 & 0.2 & 0.0 & 0.1 & \\
\hline Weaving, knitting machines for preparing yarns & 7245 & 34321 & 0.5 & 7.8 & 0.4 & 0.1 & 0.0 & \\
\hline Mineral or chemical fertilizers, phosphates & 5622 & 33535 & 0.5 & 0.0 & 1.5 & & 0.0 & \\
\hline Other tubes and pipes, of iron or steel & 6783 & 32503 & 0.5 & 4.1 & 1.1 & 0.1 & 0.0 & \\
\hline Polyethylene & 5831 & 32308 & 0.5 & 0.5 & 0.1 & 0.0 & 0.0 & \\
\hline Miscellaneous articles of materials of div.58 & 8939 & 32298 & 0.5 & 2.5 & 0.3 & 0.2 & 0.2 & $\overline{0.0}$ \\
\hline Paper and paperboard in rolls or sheets & 6415 & 31815 & 0.5 & 24.7 & 0.2 & 0.0 & 0.0 & \\
\hline Synthetic organic dyestuffs & 5311 & 30951 & 0.5 & 43.7 & 5.9 & 0.0 & 0.0 & \\
\hline Aluminium and aluminium alloys & 6841 & 30042 & 0.4 & 79.6 & 0.4 & 0.0 & & \\
\hline Polyvinyl chloride & 5834 & 29616 & 0.4 & 1.0 & 0.2 & 0.0 & 0.0 & \\
\hline Tulle, lace, embroidery, ribbons & 6560 & 29494 & 0.4 & 1.5 & 1.7 & 1.0 & 2.1 & \\
\hline
\end{tabular}

Source: Calculated using UN COMTRADE Database

Notes: A value of 0.0 represents less than US\$100 in exports; blanks represent zero exports. 


\begin{tabular}{|c|c|c|c|c|c|c|c|c|}
\hline & & \begin{tabular}{|c|} 
Imports \\
$\left(\${ }^{\prime} 000\right)$
\end{tabular} & Imports & $\begin{array}{l}\text { Imports } \\
\text { from } \\
\text { SACs }\end{array}$ & India & Pakistan & $\begin{array}{c}\text { Bangla- } \\
\text { desh }\end{array}$ & Nepal \\
\hline Knitted/crocheted fabrics of fibers other than synthetic & 6552 & 275888 & 5.3 & 1.8 & 0.4 & 4.1 & 0.4 & \\
\hline Fabrics, woven containing $85 \%$ of discontinuous synth. fibers & 6532 & 152080 & 2.9 & 1.8 & 2.1 & 0.0 & 0.0 & \\
\hline Motor vehicles for transport of goods/materials & 7821 & 137146 & 2.6 & 4.6 & 0.1 & 0.0 & 0.0 & \\
\hline Diamonds, unworked, uncut/or worked but not mounted/set & 6672 & 135765 & 2.6 & 1.5 & 24.0 & & & \\
\hline Coated/impregnated textile fabrics \& products n.e.s. & 6573 & 102573 & 2.0 & 1.4 & 18.6 & 0.4 & 0.4 & \\
\hline Milk \& cream, preserved, concentrated or sweetened & 0224 & 101782 & 2.0 & 0.0 & 0.0 & 0.1 & & \\
\hline Fabrics, woven, of discontinuous synthetic fibers & 6534 & 96270 & 1.8 & 7.9 & 3.5 & 0.0 & 5.2 & \\
\hline Cotton fabrics, woven, unbleached, not mercerized & 6521 & 87422 & 1.7 & 20.2 & 19.4 & & 0.2 & \\
\hline Tulle, lace, embroidery, ribbons, \& other small wares & 6560 & 83694 & 1.6 & 1.2 & 1.7 & 1.0 & 0.0 & \\
\hline Small-wares and toilet articles, feather dusters etc. & 8998 & 62076 & 1.2 & 1.3 & 0.4 & 0.0 & 0.1 & 0.7 \\
\hline Medicaments(including veterinary medicaments) & 5417 & 58363 & 1.1 & 44.3 & 1.6 & & 0.0 & \\
\hline Cotton yarn & 6513 & 56237 & 1.1 & 52.2 & & & 0.0 & \\
\hline Beans, peas, lentils \& other leguminous vegetables & 0542 & 53006 & 1.0 & 59.1 & 3.5 & 0.2 & & 105.5 \\
\hline Palm oil & 4242 & 46998 & 0.9 & 0.7 & 0.0 & 0.0 & & \\
\hline Tobacco, not stripped & 1211 & 45782 & 0.9 & 3.4 & 10.4 & 0.9 & 1.0 & \\
\hline Rice semi-milled or wholly milled, broken rice & 0422 & 45764 & 0.9 & 86.9 & 31.7 & 47.7 & 0.0 & 4.1 \\
\hline Fabrics, woven of continuous synthetic textile materials & 6531 & 43866 & 0.8 & 0.2 & 1.9 & 24.0 & 0.0 & \\
\hline Mineral or chemical fertilizers, nitrogenous & 5621 & 42720 & 0.8 & 0.0 & 0.1 & & 10.0 & \\
\hline Yarn containing $85 \%$ by weight of synthetic fibers, not for sale & 6514 & 42706 & 0.8 & 5.2 & 0.9 & 2.7 & 0.0 & 0.0 \\
\hline Miscellaneous articles of materials of div.58 & 8939 & 41534 & 0.8 & 2.3 & 0.3 & 0.2 & 0.0 & 0.0 \\
\hline Other fresh or chilled vegetables & 0545 & 30368 & 0.6 & 78.8 & 1.1 & 0.9 & 1.6 & 0.0 \\
\hline Fabrics, woven containing $85 \%$ discontinuous regen. fibers & 6536 & 29718 & 0.6 & 0.7 & 0.5 & & & \\
\hline Public-service type passenger motor vehicles etc. & 7831 & 29345 & 0.6 & 59.7 & 1.4 & 0.0 & & \\
\hline Insulated, electrical wire, cable, bars, strips etc. & 7731 & 28597 & 0.5 & 4.1 & 0.1 & 0.0 & & \\
\hline Motorcycles, auto-cycles and cycles with an auxiliary motor & 7851 & 27863 & 0.5 & 14.7 & 0.9 & 0.1 & 0.0 & \\
\hline Machinery \& appliances for specialized particular industries & 7284 & 27611 & 0.5 & 12.8 & 0.3 & 0.1 & 0.4 & \\
\hline Blooms, billets, slabs \& sheet bars of iron or steel & 6725 & 26627 & 0.5 & 9.1 & 0.3 & 0.0 & & \\
\hline Gold, non-monetary & 9710 & 26468 & 0.5 & & & & & \\
\hline Printing paper \& writing paper, in rolls or sheets & 6412 & 26318 & 0.5 & 7.5 & 0.1 & & & \\
\hline Television receivers, colour & 7611 & 24211 & 0.5 & 4.0 & 0.1 & 0.0 & & \\
\hline Other parts \& accessories of motor vehicles & 7849 & 22796 & 0.4 & 28.6 & 0.2 & 0.0 & 0.0 & \\
\hline Potatoes, fresh or chilled, excluding sweet potatoes & 0541 & 22249 & 0.4 & 89.6 & 0.1 & 4.7 & & \\
\hline Parts of apparatus of division 76--- & 7649 & 22235 & 0.4 & 0.5 & 0.0 & 0.0 & 0.0 & \\
\hline Kraft paper and paperboard, in rolls or sheets & 6413 & 22040 & 0.4 & 6.2 & 0.2 & 0.0 & & \\
\hline
\end{tabular}

$N$ Source: Calculated using UN COMTRADE Database

Notes: A value of 0.0 represents less than US\$100 in exports; blanks represent zero exports. 


\begin{tabular}{|c|c|c|c|c|c|c|c|c|}
\hline & & Nepal & & & & & & \\
\hline Product Description & SITC & Total & Share of & Share of & & RCA inc & dices & \\
\hline & & $\begin{array}{l}\text { Imports } \\
\left(\${ }^{\prime} 000\right)\end{array}$ & Imports & $\begin{array}{c}\text { Imports } \\
\text { from SACs }\end{array}$ & India & Pakistan & $\begin{array}{c}\text { Bangla- } \\
\text { desh }\end{array}$ & $\begin{array}{c}\text { Sri } \\
\text { Lanka }\end{array}$ \\
\hline Gold, non-monetary & 9710 & 250335 & 32.9 & 0.0 & & & & 0 \\
\hline UN Special Code & 9310 & 77805 & 10.2 & 1.3 & 0.8 & 0.0 & 0.1 & 0.9 \\
\hline Edible nuts (excluding nuts used for the extraction of oil) & 577 & 26658 & 3.5 & 4.8 & 16.5 & 0.2 & & 50.7 \\
\hline Sheep's or lambs' wool, greasy or fleece-washed & 2681 & 22601 & 3 & 0 & 0.1 & 0.0 & & \\
\hline Passenger motor cars, transporting passengers \& goods & 7810 & 22871 & 3 & 0.5 & 0.1 & 0.0 & 0.0 & 0.0 \\
\hline Aircraft not exceeding an unladen weight $15000 \mathrm{~kg}$ & 7923 & 20345 & 2.7 & 0 & & & & 0.4 \\
\hline Raw silk (not thrown) & 2613 & 19693 & 2.6 & 0 & 0.5 & & & \\
\hline Other polymerization and copolimerization products & 5839 & 19527 & 2.6 & 0.1 & 0.2 & 0.0 & 0.0 & 0.0 \\
\hline Electrical line telephonic \& telegraphic apparatus & 7641 & 19483 & 2.6 & 0.0 & 0.0 & 0 & & 0.0 \\
\hline Mineral or chemical fertilizers, nitrogenous & 5621 & 17136 & 2.2 & 16.3 & 0.1 & & 10 & 0.0 \\
\hline Soya bean oil & 4232 & 14456 & 1.9 & 0 & 0 & & & 0.0 \\
\hline Spices (except pepper and pimento) & 752 & 12427 & 1.6 & 0 & 16.8 & 8.5 & 0.0 & 156.8 \\
\hline Electro-medical apparatus & 7741 & 10709 & 1.4 & 0.4 & 0.1 & & & 0.0 \\
\hline Fabrics, woven of continuous synthetic textile materials & 6531 & 9082 & 1.2 & 0.1 & 1.9 & 24 & 0.0 & 0.7 \\
\hline Cotton yarn & 6513 & 8485 & 1.1 & 0.0 & 24.9 & 92.6 & 0.0 & 2.6 \\
\hline Refractory bricks \& other refractory construction materials & 6623 & 8746 & 1.1 & 0.0 & 0.6 & 0.0 & 0.0 & 0.3 \\
\hline Ball, roller or needle roller bearings & 7491 & 8085 & 1.1 & 0.0 & 0.5 & 0.0 & & 0.00 \\
\hline Other electrical machinery and equipment & 7788 & 8459 & 1.1 & 0.1 & & & & \\
\hline Other prepared or preserved meat & 149 & 7462 & 1 & 0.4 & 0.0 & 0.0 & & 0.0 \\
\hline Printed matter, n.e.s. & 8928 & 7337 & 1 & 1.5 & 0.1 & & 0.0 & 0.7 \\
\hline Other non-ferrous base metal, n.e.s. & 2882 & 6831 & 0.9 & 0 & 0.1 & 0.3 & & 0.3 \\
\hline Palm oil & 4242 & 6548 & 0.9 & 0 & 0 & & & 0.0 \\
\hline Lifting, handling, loading machinery. conveyors & 7442 & 6917 & 0.9 & 0.1 & 0.1 & 0.0 & 0.1 & 0.0 \\
\hline Analogue \& hybrid data processing machines & 7521 & 7238 & 0.9 & 0.4 & 0 & & & 0.2 \\
\hline Photographic, cameras, parts \& accessories & 8811 & 6379 & 0.8 & 0 & 0 & & 0 & 0.0 \\
\hline Cotton fabrics, woven, unbleached, not mercerized & 6521 & 5353 & 0.7 & 52.5 & 16.4 & 70.9 & 0.2 & 9.6 \\
\hline Public-service type passenger motor vehicles etc. & 7831 & 5358 & 0.7 & 5.1 & 1.4 & 0 & & 0.0 \\
\hline Medicaments (including veterinary medicaments) & 5417 & 4229 & 0.6 & 2.6 & 1.6 & 0.3 & 0 & 0.0 \\
\hline Office machines, n.e.s. & 7518 & 4575 & 0.6 & 0 & 0 & & 0 & 0.0 \\
\hline Aldehyde-, ketone-,\& quinone-function compounds & 5162 & 3523 & 0.5 & 2.7 & 1.8 & & & 0.0 \\
\hline Zinc and zinc alloys, unwrought & 6861 & 4055 & 0.5 & 0 & 0.2 & 0.0 & & \\
\hline Electrical measuring, checking, analysing instruments & 8748 & 3565 & 0.5 & 0.6 & 0.1 & 0.0 & & \\
\hline Armored fighting vehicles, arms of war \& ammunition & 9510 & 4000 & 0.5 & 0 & 0 & 0.0 & & 0.0 \\
\hline Meal and flour of wheat and flour of meslin & 460 & 2940 & 0.4 & 81.3 & 0.1 & & & 0.0 \\
\hline Waste and scrap metal of iron or steel & 2820 & 2999 & 0.4 & 0.0 & 0.0 & 0.0 & 0.0 & 1.5 \\
\hline Television receivers, color & 7611 & 3392 & 0.4 & 0.1 & 0.1 & 0.0 & & 0.0 \\
\hline Radio-broadcast receivers portable, incl. sound recording & 7622 & 2766 & 0.4 & 0.1 & 0 & & & 0.0 \\
\hline Footwear & 8510 & 3289 & 0.4 & 2.6 & 1.6 & 0.7 & 1.2 & 0.1 \\
\hline Watches, watch movements and cases & 8851 & 2822 & 0.4 & 0 & 0.2 & 0.0 & & 0.0 \\
\hline Oil seeds and oleaginous fruit, n.e.s. & 2238 & 2477 & 0.3 & 72.3 & 7.4 & 17.1 & & 0.1 \\
\hline Coconut (copra) oil & 4243 & 1969 & 0.3 & 0 & 0.2 & & & 7.3 \\
\hline Perfumery, cosmetics and toilet preparations & 5530 & 2516 & 0.3 & 0.1 & 0.7 & 0.1 & 0.0 & 0.1 \\
\hline Fabrics, woven, of silk, of noil or other waste silk & 6541 & 2662 & 0.3 & 0 & 16.8 & 0.2 & & 0.1 \\
\hline Copper and copper alloys, worked & 6822 & 2242 & 0.3 & 0 & 0.2 & 0.0 & & 0.0 \\
\hline Electrical motors \& generators, generating sets & 7162 & 2489 & 0.3 & 0.4 & 0.2 & 0.0 & 0.0 & 0.0 \\
\hline Household type refrigerators \& food freezers & 7752 & 2543 & 0.3 & 0.0 & 0.1 & 0.0 & & 0.0 \\
\hline Batteries and accumulators and parts & 7781 & 2558 & 0.3 & 0.0 & 0.3 & 0.0 & 0.00 & 0.1 \\
\hline Lighting fixtures and fittings and parts & 8124 & 2653 & 0.3 & 0.0 & 0.1 & 0.0 & 1.1 & 4.6 \\
\hline Miscellaneous articles of materials of div.58 & 8939 & 2549 & 0.3 & 0.0 & 0.3 & 0.2 & 0 & 0.4 \\
\hline Hygienic and pharmaceutical articles of rubber & 6281 & 1885 & 0.2 & 0.0 & 5.6 & 0.2 & 0 & 4.1 \\
\hline
\end{tabular}

Source: Calculated using UN COMTRADE Database

Notes: A value of 0.0 represents less than US\$100 in exports; blanks represent zero exports. 
The extent of the disparity between imports and products representing an RCA index less than unity among its regional partners is the highest for Nepal. Nepal's 50 major imports represent 92 percent of Nepal's total imports (by value); for over 70 percent of these products the regional members show an RCA less than one, suggesting the extent to which the region is lacking in "efficiency" to meet Nepal's import needs.

As seen from the above, the evidence for a successful regional bloc based on complementarities in comparative advantage is rather mixed. Bangladesh and, to some extent, Sri Lanka can look to the region to meet some of their import needs, which are met mostly by India and to a limited extent by Pakistan. The extent to which the rest of the region meets the import needs based on the current specializations may be a critical obstacle to the successful implementation of the FTA. The prospects of enhancing regional trade hinges upon the extent to which smaller countries can increase exports to India and vice versa, appears to be narrow. A second crucial feature that emerges from Table 7 is that, among those products for which South Asia appears to be an efficient supplier (RCA > 1), the regional members have tended to import an insignificant share from other regional countries, suggesting that product differentiation (quality, durability) and prospects for intraindustry trade remain low. It is unlikely that the FTA would have any impact, as these export-oriented imports are already duty-free, including textile products that countries like Sri Lanka and Bangladesh heavily rely on for their apparel exports. Therefore (except for exchange rate and other indirect effects) there would be little effect on imports (including imports from other South Asian countries) with preferential or free trade agreements.

On the other hand, it must be noted that, up to and including the latest data year analyzed (1998), India implemented very extensive quantitative restrictions, which for most manufactured consumer goods and some primary commodities amounted to an import ban. As a result, many of these products were not being imported at all or in small quantities, either from ROW or from the other South Asian countries. Consequently, these products are not picked up in the current analysis of recent trade patterns, even though it is likely that at least some of them, in the absence of quantitative restrictions, would have been exported from the other South Asian countries to India. The impact of such restrictions must be recognized in drawing conclusions in the succeeding analyses. 


\section{Complementarity Test}

An additional summary measure that can test complementarity among members of a prospective FTA is the "complementarity index," which tests how well structures of imports and exports match. The complementarity index test offers a different dimension of complementarity, taking into account the closeness of a country's commodity trade structure relative to the world trade structure and their import and export specialization. ${ }^{28}$ The index ranges from zero (when none of the goods exported matches with imports of the other countries) to 100 (when export shares perfectly correspond with imports). ${ }^{29}$ Proponents of the index, such as Michaely (1994) and Yeats (1998), argue that the higher its value, the more likely a proposed regional trade arrangement will succeed. An increasing tendency of the index between two members can also provide some indication of the likelihood of their further integration. The complementarity index is defined as follows:

$$
\text { (3) } I T C_{i j}=\sum_{k} \frac{X_{i w}^{k}}{X_{i w}} * \frac{M_{w w}-M_{i w}}{M_{w w}^{k}-M_{i w}^{k}} * \frac{M_{j w}^{k}}{M_{j w}}
$$

The index of complementarity in country $i$ 's exports to country $j$ is the weighted sum of the products of each commodity's share in country $i$ 's exports and in country $j$ 's imports, with commodities weighted by the inverse of their shares in world trade. The weighting is necessary because country $j$ is more likely to buy commodity $k$ from country $i$ if other countries are simply not exporting much of commodity $k .^{30}$

The observed pattern of low complementarities is consistent with the trade complementarity indices reported in Table 9. The measured degree of complementarity among countries is very low. There are some notable exceptions, such as the indices between of Sri Lanka and Pakistan, where both have experienced a

${ }^{28}$ Drysdale (1967) developed the index to separate out the impact of the commodity composition of countries' trade complementarity) from other factors.

${ }^{29}$ The index has some limitations that should be noted. First it takes the existing structure (share) of exports as given and attempts to determine how well it matches a potential partner's imports. This assumes that either existing exports will be diverted to the regional partner, or the country can expand these exports at constant costs. Furthermore, the index treats all exports as equal, yet some may have very different associated national policy objectives. Finally, the impact of distance and transport costs are neglected in the complementarity index.

${ }^{30}$ Yeats (1998) points out that the index has its limitations. Yeats noted that it "takes the existing structure (share) of exports as a given and attempts to determine how well it matches a potential partner's imports. This assumes that either existing exports will be diverted to the regional partner, or the country can expand these exports at constant costs. Also, the approach assumes there is something optimal about the existing structure of trade. This need not be the case. Third, the complementarity index treats all exports as equals, yet some may have very different associated national policy objectives. Fourth, the influence of distance and transport costs are neglected in the complementarity index." 
steady increase in complementarity over the selected years. A slight increase in export complementarity is also evident between India and Bangladesh, but, to a lower extent than those between Sri Lanka and Pakistan. Are these encouraging in terms of achieving SAFTA? To address this question we compare complementarity indexes for a set of sample regions, at the inception of their respective regional trade agreements. Table 9 also provide indices of more successful arrangements, such as the European Union, the North American Free Trade Agreement, and Mercosur: in this context the prospects do not seem very promising for South Asia. The high complementarity ratios suggest comparable import and export structures among member countries in those regions. 
Table 9: Trade Complementarity Index of Major South Asian Countries

\begin{tabular}{|c|c|c|c|c|c|}
\hline \multirow{2}{*}{$\begin{array}{c}\text { Importing } \\
\text { Country }\end{array}$} & \multicolumn{5}{|c|}{ Exporting Country } \\
\hline & & Bangladesh & India & Pakistan & Sri Lanka \\
\hline \multirow[t]{6}{*}{ India } & 1975 & 0.04 & - & 0.16 & 0.10 \\
\hline & 1980 & 0.04 & - & 0.23 & 0.70 \\
\hline & 1990 & 0.19 & - & 0.34 & 1.04 \\
\hline & 1995 & 0.18 & - & 0.50 & 0.17 \\
\hline & 1997 & 0.47 & - & 0.42 & \\
\hline & 1998 & 1.59 & - & 0.37 & 0.76 \\
\hline \multirow[t]{6}{*}{ Pakistan } & 1975 & 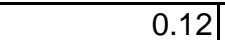 & $\overline{0.07}$ & - & 1.07 \\
\hline & 1980 & 0.98 & 0.07 & - & 6.89 \\
\hline & 1990 & 0.16 & 0.39 & - & 8.11 \\
\hline & 1995 & 0.23 & 0.83 & - & 4.91 \\
\hline & 1997 & 0.52 & 1.45 & - & \\
\hline & 1998 & 2.51 & 1.55 & - & 8.17 \\
\hline \multirow[t]{5}{*}{ Bangladesh } & 1975 & -1 & 0.43 & 4.48 & 0.10 \\
\hline & 1980 & - & 1.13 & 3.68 & 0.24 \\
\hline & 1990 & - & 1.2 & 3.23 & 0.36 \\
\hline & 1997 & - & 4.12 & 0.54 & - \\
\hline & 1998 & - & 3.21 & 8.25 & 1.05 \\
\hline \multirow[t]{5}{*}{ Sri Lanka } & 1975 & 0.33 & 0.64 & 12.02 & - \\
\hline & 1980 & 0.12 & 1.24 & 2.63 & - \\
\hline & 1990 & 1.18 & 1.64 & 2.81 & - \\
\hline & 1995 & 0.39 & 1.98 & - & - \\
\hline & 1998 & 0.97 & 2.65 & 4.12 & - \\
\hline Nepal & 1998 & & 1.28 & & 1.75 \\
\hline \multicolumn{2}{|l|}{ South Asia } & 1.3 & MERCOSUR & & 28.6 \\
\hline \multicolumn{2}{|c|}{ European Community } & 53.4 & Canada-USA & TA & 64.3 \\
\hline \multicolumn{2}{|l|}{ NAFTA } & 56.3 & LAFTA & & 22.3 \\
\hline \multicolumn{2}{|l|}{ Andean Pact } & 7.4 & & & \\
\hline
\end{tabular}

Notes: Data are presented column-wise (i.e. Figures show trade complementarily of country listed in column 1 with each country listed in row 1).

Sources: Calculated from the WITS Database, World Bank. Each country index is derived by computing the complete schedule of exports at SITC 4-digit level .

The complementarity Index for other regions EU, NAFTA, Mercosur, LAFTA, and Andean Pact is obtained from Yeats (1998).

The measures for the Andean Pact were an exception among these groups. They were low enough to suggest that imports and exports between the member countries were largely similar and may have contributed to its failure (Yeats, 1998). The weighted average of the complementarity index for South Asia does not compare well even with the Andean Pact. The underlying "mismatch" between the import and export structures for most members in South Asia implies that South Asia will continue to rely on non-regional 
sources for its key imports for facilitating industrialization and growth, and will continue to rely on nonregional markets to absorb its major exports. This limitation will generally restrict the potential impact of regional trade arrangements among South Asian countries.

\section{Are South Asian Countries in Competition with Each Other?}

While low complementarities raise concerns about the capacity of existing industrial and agricultural structures in South Asian countries to support greater regional trade integration, the interpretation on the flipside is that their export structures are highly 'competitive'. The empirical evidence suggests that this is a negative attribute for the formation of a successful FTA. ${ }^{31}$ Theory suggests that the higher the difference in factor endowments, demonstrated by comparative advantages, the greater are the prospects for trade among partners. ${ }^{32}$ This implies that, in principle, countries with different RCA profiles have more opportunities to trade with one another than those with similar RCA profiles. ${ }^{33}$ This section attempts to complement the section above by examining more closely the degree of similarity between the members of the South Asian countries, comparing their trade and comparative advantages.

Table 10 presents a summary tabulation based on descriptive statistics in annex Table A4, which highlights the top 50 exports of selected South Asian countries in 1998 and their respective RCA profiles. ${ }^{34}$ The ratio in Table 10 demonstrates that SACs (with the exception of India) are significantly competitive with each other in their exports. For example, nearly 90 percent of Bangladesh's exports are similar to those of at least one or more regional trading partners. Pakistan's exports closely follow with an 83 percent share in competition with another member. The shares for Sri Lanka and Nepal are 77.1 percent and 73.9 percent, which sums up the extent to which these four members are competing with each other in third markets.

\section{Table 10: Competition Summary}

\footnotetext{
31 De Melo et al. (1993).

32 Yeats (1998).

33 RCA indices may also indicate the robustness of the product being exported. Products with strong RCA indices are likely to be continued exports than those with weaker RCAs.

34 The top 50 exports were chosen as they account for between 62 percent (India) and 98 percent (Bangladesh) of SAARC members; therefore, they are sufficient to deduce reasonable conclusions. Note that the top 50 exports constitute a substantial share of SACs total exports.
} 


\begin{tabular}{|l|c|c|c|c|c|}
\hline & India & Pakistan & Bangladesh & Sri Lanka & Nepal \\
\hline $\begin{array}{l}\text { Share of Total Exports Representing Top 50 } \\
\text { Products }\end{array}$ & 62.5 & 99.0 & 98.0 & 90.0 & 80.0 \\
\hline $\begin{array}{l}\text { Share of Competing Products in Total } \\
\text { Exports }\end{array}$ & 32.1 & 82.7 & 89.8 & 77.1 & 73.9 \\
\hline Share of Competing Products with RCA >1 & 29.7 & 82.3 & 89.6 & 75.7 & 73.8 \\
\hline
\end{tabular}

Notes: *The number products exported at SITC 4-digit level matching the exports of at least one regional trading partner, as a share of total exports.

Source: WITS and SIMA databases, World Bank.

When comparison is made between those products in which RCA > 1, the conclusion above remain unchanged. More than 89 percent of Bangladesh's globally competitive exports coincide with those of at least one regional partner. The extent of competition among Nepal, Pakistan, and Sri Lanka is marginally lower than that of Bangladesh. This characteristic in export profiles underscores the extent of complexity involved in creating an environment that encourages regional competition for those products with global efficiency. Only India offers any noteworthy share of efficient exports that are dissimilar to others in the region, and therefore offers the prospects for significantly expanding regional trade.

The lack of complementarity and high degree of competition in export structures imply daunting prospects for expanding regional trade in South Asia. It seems that general liberalization efforts, which helped countries to increase efficiency, have evolved among a narrow range of products largely dominated by textiles and apparel. Ironically, these are precisely the products for which the countries have demonstrated a reluctance to totally dismantle existing trade barriers. For instance, competition between Bangladesh, Pakistan and Sri Lanka seems to emerge primarily in textiles and apparel exports, which occupy the major share in each of their comparative advantages. $^{35}$ With the exception of its FTA agreement with Sri Lanka, through which India provides market access through quotas, India nevertheless remains vehemently opposed to liberalization of textiles and apparel under any of its regional agreements.

\footnotetext{
${ }^{35}$ Note, however, that product differentiation can provide for complementarities even in textile and apparel., paving the way for mutually beneficial trade. This can only be established at a further disaggregation, for example at HS 6-digit level, which is beyond the scope of the current study.
} 


\section{Conclusion}

The above analysis, using various definitions of the "natural trading partner" hypothesis, demonstrates that the South Asian countries can be characterized only moderately as "natural trading partners". Additional statistical measures evaluating the evolving trade patterns among SACs point to further obstacles to a rapid increase in intra-regional trade. The evidence is as follows:

First, the "volume of trade" criterion for "natural trading partners" (Lipsey, 1960; Summers, 1990) suggests that the South Asian countries fall short of this characterization. Bhutan and Nepal—which, by virtue of being landlocked and smaller in size, maintain strong trade links with India-are exceptions to the overall low shares of intra-regional trade. None of the other countries trade "disproportionately" within the region.

The evidence of South Asia's recent trade patterns also does not strongly support another version of the hypothesis that characterizes "natural trading partners" on the basis of geographical proximity (Wonnacott and Lutz, 1989; Deardorff and Stern, 1994). The countries of the South Asian region have, instead, demonstrated an increasing tendency to trade relatively intensively with partners outside the region, due to either pure endowment differences — that is, vis-à-vis industrial countries—or due to long-standing cultural, ethnic, and/or religious affiliations.

In terms of "trade complementarity" - a third criterion of the natural trading partner hypothesis (Schiff, 1999; Michaely, 1996) - the evidence on South Asia is mixed. India's, and to a limited extent Pakistan's, more efficient exports (defined by RCA indices greater than one) complement the import demands of a number of countries in the region, particularly those of Bangladesh and Sri Lanka. However, the other South Asian countries display efficiencies in only a limited range of products that can fulfill India's or any other regional members' major import requirements.

Mirroring the lack of complementarity among the members' trade patterns is the highly competing nature of their trade. Except for India, most of the countries in the region are competitors in their export 
markets in a narrow range of products—dominated by textile and apparel exports—which may further inhibit the prospects of increasing regional trade to the level envisioned under SAFTA.

The evidence suggests that the products for which the region demonstrates strong comparative advantages are predominantly labor-intensive manufactured goods. There is limited evidence that the rise in intra-regional trade has provided opportunities for these most dynamic exports, for which the South Asian countries appear to be competing against each other in third markets. It should be noted, however, that up to and including the latest data year analyzed (1998), India implemented very extensive quantitative restrictions, which for most manufactured consumer goods and some primary commodities amounted to an import ban. As a result, many of these products were not being imported at all or in small quantities, either from ROW or from the other South Asian countries. Consequently, these products are not picked up in the various indices, especially the complementary indices, even though it is likely that at least some of them would have been exported from the other South Asian countries to India in the absence of such restrictions.

At the same time, the evidence here is consistent with empirical evidence from other developing countries that suggests that more dynamic exporters tend to rely less on other developing country markets. ${ }^{36}$ In effect, South Asia's trade patterns tend to support the Heckscher-Ohlin model of trade for developing countries. Therefore, it is plausible to assume that the highest gains are likely to continue to accrue in those sectors and markets for which South Asia has a high differential in factor endowments, i.e. vis-à-vis industrial countries.

While this static analysis, based on recently evolving trade patterns, points to trade structures that may hinder the rapid, successful implementation of SAFTA, there is evidence that unilateral, non-discriminatory trade liberalization has already helped the South Asian countries to refine their incentive environments by reducing distortions and has helped to enhance the region's competitiveness in manufactured exports. ${ }^{37}$ Continuing on the process of unilateral liberalization would be more likely to mitigate any welfare decreasing

\footnotetext{
${ }^{36}$ Havrylyshyn (1987).

37 Atukorala (1999), IMF (1995).
} 
effects that a preferential trade arrangement may induce through trade diversion. ${ }^{38}$ More importantly, continuing unilateral/multilateral liberalization would likely help South Asia to further diversify and evolve new comparative advantages and complementarities, thus, creating the requisite environment for the successful implementation of SAFTA.

${ }^{38}$ Panagariya (2001) demonstrates how preferential liberalization in South Asia involves substantial trade diversions. 


\section{References}

Anderson, K. and Blackhurst, R. ed. (1993). "Regional Integration and the Global Trading System", London and New York, Harvester, Wheatsheaf..

Braga, C., Safadi, R. and Yeats, A. (1994). "Regional Integration in the Americas, Déjà vu All Over Again?" The World Economy, July.

Deardorff, A. and Stern, R.M. (1994) "Multilateral Trade Negotiations and Preferential Trade Arrangements." Chapter 2 in Deardorff and Stern (eds), Analytical and Negotiating Issues in the Global Trading System. Ann Arbor: University of Michigan Press.

De Melo, J., Panagariya, A. and Rodrik, D. (1993) The New Regionalism: A Country Perspective, World Bank.

Havrylyshyn. O. (ed.) (1987) Exports of Developing Countries: How Direction Affects Performance, World Bank.

Hertel, T., Martin, W., Yanagishima, K. and Dimaranan, B. (1995) "Liberalizing Manufactures Trade in a Changing World Economy." Chapter 4 in W. Martin and L.A Winters (eds), The Uruguay Round and the Developing Countries, World Bank.

IMF (1995) "India: Economic Reform and Growth,” Occasional Paper No. 134.

Kathuria S., Martin, W. and Bhradwaj, A. (1999) "Implications of MFA Abolition for South Asian Countries," Mimeo, World Bank.

Lipsey, R. (1960) "The Theory of Customs Unions: A General Survey," Economic Journal 70: 498-513.

Mayer, J. and Adrian, W, (2000) "South Asia's Export Structure in a Comparative Perspective," IDS Working Paper, No. 91.

Mehta, R. and Bhattacharya, K. (1999) "SAPTA to SAFTA: Impact on Intra-Regional Trade," submitted to the $35^{\text {th }}$ Annual Conference of the Indian Econometric Society, Jaipur, India, 11-13 March 1999.

Ng, F. and Yeats, A. (2003) "Major Trade Trends in East Asia: What are their Implications for Regional Cooperation and Growth?" Policy Research Working Paper \#3084, World Bank.

Michaely, M. (1996), "Trade Preferential Agreements in Latin America: An Ex Ante Assessment," Policy Research Working Paper, No. 1583, World Bank.

Mukherji, I.N. 2000. "Charting a Free Trade Area in South Asia: Instruments and Modalities." Paper presented to the Second Conference of the South Asia Network of Economic Research Institute (SANEI), August 28-29, Katmandu.

Panagariya, A. (2000) "Preferential Trade Liberalization: The Traditional Theory and New Developments," Journal of Economic Literature, Vol. XXXVIII, June.

Panagariya, A. (2001) "South Asia: Does Preferential Trade Liberalization Make Sense?" Mimeo, University of Maryland.

Pigato, M., Farah, C., Itakura, K., Kwang, J., Martin, Wi., Murrell, K. and Srinivasan, T.G. (1997) South Asia's Integration into the World Economy, World Bank

Pitigala, N. (1998) "The BOI: Catalyst for Development," Mimeo, Ministry of Finance and the Board of Investment of Sri Lanka,.

Pitigala, N. and Baysan T. (2001) "Has Unilateral Liberalization Encourage Regional Trade in South Asia?" Mimeo, World Bank.

Pursell, G. and Pitigala, N. (2001) “Trade Agreements in South Asia Region,” Mimeo, World Bank. 
Schiff, M. (2001) "Will the Real 'Natural Trading Partner' Please Stand Up?" Journal of Economic Integration, Vol. 16, No. 2.

(1993) "Small is Beautiful, Preferential Trade Agreements and the Impact of Country Size, Market Share, Efficiency and Trade Policy," World Bank.

Srinivasan, T.N. and Canonero, G. (1994) "Regional Trading Arrangements and Beyond: Exploring Some Options for South Asia - Theory, Empirics and Policy," World Bank.

(1997) "Liberalization of Trade Among Neighbors: Two Illustrative Models and Simulations," South Asia Discussion Paper Series, Supplement II to IDP\#142, World Bank.

Summers, L. (1991) "Regionalism and the World Trading System," in Symposium on Policy Implications of Trade and Currency Zones, sponsored by the Federal Reserve Bank of Kansas City.

Taneja N., (1999) “Informal Trade in the SAARC Region,” ICRIER, Delhi, Working Paper No. 45.

Venables, A.J. (1999) "Regional Integration Agreements: A Force for Convergence or Divergence?" Policy Research Working Paper No. 2260, World Bank.

Yeats, A. (1998) "What Can Be Expected from African Regional Trade Arrangements? Some Empirical Evidence," Policy Research Working Paper, No. 2004, World Bank.

(1996) "Export Prospects of Middle East Countries," Policy Research Working Paper, No. 1571, World Bank.

Wonnacott, P. and Lutz, M. (1989) "Is there a Case for Free Trade Areas?" In J.J. Schott (ed.), Free Trade Areas and U.S Trade Policy, pp. 59-84. Washington, D.C.: Institute of International Economics.

Winters, L.A. (1996) "Regionalism verses Multilateralism,” Mimeo, World Bank. 
Annex Table A1: Regional Trade as Share of Total Trade in South Asia

\begin{tabular}{|c|c|c|c|c|c|c|c|c|c|}
\hline \multirow[t]{2}{*}{ Country } & \multirow[t]{2}{*}{ Trading Partner } & \multicolumn{4}{|c|}{ Exports } & \multicolumn{4}{|c|}{ Imports } \\
\hline & & 1981 & 1990 & 1995 & 1998 & 1981 & 1990 & 1995 & 1998 \\
\hline \multirow[t]{7}{*}{ India } & Bangladesh & 0.72 & 1.67 & 3.14 & 2.83 & 0.09 & 0.06 & 0.23 & 0.15 \\
\hline & Bhutan & 0.00 & 0.00 & 0.04 & 0.03 & 0.00 & 0.00 & 0.05 & 0.03 \\
\hline & Maldives & 0.01 & 0.03 & 0.04 & 0.02 & 0.00 & 0.00 & 0.00 & 0.00 \\
\hline & Nepal & 1.16 & 0.22 & 0.35 & 0.88 & 0.31 & 0.06 & 0.08 & 0.34 \\
\hline & Pakistan & 0.05 & 0.24 & 0.23 & 0.37 & 0.53 & 0.19 & 0.11 & 0.50 \\
\hline & Sri Lanka & 0.96 & 0.57 & 1.26 & 1.46 & 0.38 & 0.09 & 0.11 & 0.10 \\
\hline & As share of Total & 2.89 & 2.73 & 5.06 & 5.59 & 1.31 & 0.41 & 0.58 & 1.13 \\
\hline \multirow[t]{7}{*}{ Pakistan } & Bangladesh & 2.07 & 1.84 & 1.92 & 1.26 & 0.91 & 0.52 & 0.31 & 0.39 \\
\hline & Bhutan & 0.00 & 0.00 & 0.01 & 0.00 & 0.00 & 0.01 & 0.02 & 0.00 \\
\hline & India & 2.34 & 0.88 & 0.49 & 2.40 & 0.05 & 0.62 & 0.70 & 1.65 \\
\hline & Maldives & 0.01 & 0.01 & 0.02 & 0.02 & 0.01 & 0.00 & 0.00 & 0.00 \\
\hline & Nepal & 0.00 & 0.02 & 0.04 & 0.09 & 0.04 & 0.01 & 0.00 & 0.01 \\
\hline & Sri Lanka & 1.07 & 1.23 & 0.69 & 1.13 & 0.88 & 0.50 & 0.43 & 0.37 \\
\hline & As share of Total & 5.49 & 3.98 & 3.16 & 4.91 & 1.89 & 1.65 & 1.47 & 2.43 \\
\hline \multirow[t]{7}{*}{ Bangladesh } & Bhutan & 0.00 & 0.01 & 0.01 & 0.01 & 0.00 & 0.20 & 0.06 & 0.07 \\
\hline & India & 2.56 & 1.30 & 1.14 & 1.44 & 2.41 & 4.66 & 15.30 & 16.12 \\
\hline & Maldives & 0.00 & 0.00 & 0.00 & 0.00 & 0.00 & 0.00 & 0.00 & 0.01 \\
\hline & |Nepal & 0.03 & 0.44 & 0.32 & 0.47 & 0.44 & 0.04 & 0.06 & 0.20 \\
\hline & Pakistan & 5.34 & 1.39 & 0.85 & 0.75 & 1.75 & 1.92 & 2.12 & 1.00 \\
\hline & Sri Lanka & 0.34 & 0.49 & 0.37 & 0.03 & 0.08 & 0.22 & 0.17 & 0.09 \\
\hline & As share of Total & 8.26 & 3.63 & 2.69 & 2.70 & 4.68 & 7.04 & 17.71 & 17.48 \\
\hline \multirow[t]{5}{*}{ Sri Lanka } & Bangladesh & 0.26 & 0.52 & 0.31 & 0.13 & 0.13 & 0.34 & 0.13 & 0.02 \\
\hline & India & 2.94 & 1.07 & 0.84 & 1.04 & 4.02 & 4.48 & 9.84 & 9.95 \\
\hline & Maldives & 0.19 & 0.39 & 0.37 & 0.65 & 0.11 & 0.24 & 0.36 & 0.27 \\
\hline & Nepal & 0.00 & 0.00 & 0.00 & 0.05 & 0.00 & 0.00 & 0.02 & 0.09 \\
\hline & As share of Total & 8.81 & 3.69 & 2.65 & 2.58 & 5.19 & 6.98 & 11.43 & 11.97 \\
\hline \multirow[t]{5}{*}{ Nepal } & Bangladesh & 12.82 & 0.30 & 1.09 & 2.16 & 0.11 & 2.59 & 1.46 & 0.41 \\
\hline & India & 48.60 & 7.00 & 7.71 & 32.80 & 40.84 & 9.98 & 15.65 & 30.67 \\
\hline & Pakistan & 2.40 & 0.31 & 0.14 & 0.18 & 0.04 & 0.37 & 0.43 & 0.43 \\
\hline & Sri Lanka & & 0.05 & 0.28 & 1.10 & 0.01 & 0.47 & 0.00 & 0.15 \\
\hline & As share of Total & 63.82 & 7.66 & 9.23 & 36.25 & 41.00 & 13.40 & 17.55 & 31.67 \\
\hline \multirow[t]{5}{*}{ Maldives } & Bangladesh & 0.00 & 0.00 & 0.00 & 0.59 & 0.00 & 0.00 & 0.00 & 0.00 \\
\hline & India & 0.00 & 0.05 & 0.11 & 0.18 & 0.00 & 0.00 & 0.00 & 0.00 \\
\hline & Pakistan & 0.32 & 0.00 & 0.00 & 0.11 & 0.20 & 0.66 & 0.74 & 1.98 \\
\hline & Sri Lanka & 1.83 & 7.24 & 11.16 & 15.55 & 2.15 & 9.55 & 15.31 & 31.35 \\
\hline & As share of Total & 2.15 & 7.29 & 11.27 & 17.02 & 2.35 & 10.21 & 16.05 & 33.33 \\
\hline
\end{tabular}

Source: IMF Direction of Trade Statistics. 
Annex Table A2: Nominal Intra-regional Trade (1981-98), in current US\$

\begin{tabular}{|c|c|c|c|c|c|c|c|c|c|}
\hline \multirow[t]{2}{*}{ Country } & \multirow[t]{2}{*}{ Sub-series } & \multicolumn{4}{|c|}{ Intra-regional Exports } & \multicolumn{4}{|c|}{ Intra-regional Imports } \\
\hline & & 1981 & 1990 & 1995 & 1998| & $|1981|$ & 1990 & 1995 & 1998 \\
\hline \multirow[t]{7}{*}{ India } & Bangladesh & 49.0 & 297.1 & 959.6 & 1038.2 & 13.6 & 15.3 & 78.8 & 64.8 \\
\hline & Bhutan & 0.0 & 0.0 & 11.7 & 11.8 & 0.0 & 0.0 & 16.4 & 14.9 \\
\hline & Maldives & 0.6 & 4.7 & 12.5 & 6.7 & 0.0 & 0.0 & 0.1 & 0.2 \\
\hline & Nepal & 79.5 & 39.5 & 107.1 & 323.6 & 44.5 & 15.1 & 27.5 & 147.2 \\
\hline & Pakistan & 3.1 & 43.5 & 70.4 & 136.8 & 76.7 & 44.9 & 37.4 & 217.2 \\
\hline & Sri Lanka & 65.2 & 101.5 & 383.4 & 533.9 & 55.5 & 22.0 & 38.9 & 44.7 \\
\hline & Total & 197.4 & 486.4 & 1544.7 & 2051.0 & 190.3 & 97.3 & 199.1 & 489.0 \\
\hline \multirow[t]{7}{*}{ Pakistan } & Bangladesh & 59.6 & 102.8 & 153.4 & 106.6 & 51.3 & 38.2 & 35.0 & 36.4 \\
\hline & Bhutan & 0.0 & 0.2 & 1.0 & 0.1 & 0.0 & 0.5 & 2.3 & 0.2 \\
\hline & India & 67.4 & 49.0 & 38.8 & 202.6 & 2.8 & 45.7 & 80.6 & 153.9 \\
\hline & Maldives & 0.2 & 0.6 & 1.4 & 1.8 & 0.4 & 0.0 & 0.2 & 0.1 \\
\hline & Nepal & 0.1 & 1.1 & 3.0 & 7.6 & 2.2 & 0.4 & 0.5 & 1.3 \\
\hline & Sri Lanka & 30.7 & 68.9 & 55.1 & 95.1 & 49.6 & 37.0 & 49.6 & 34.4 \\
\hline & Total & 158.0 & 222.5 & 252.7 & 413.7 & 106.2 & 121.8 & 168.3 & 226.4 \\
\hline \multirow{7}{*}{$\begin{array}{l}\text { Banglades } \\
\mathrm{h}\end{array}$} & Bhutan & 0.0 & 0.2 & 0.3 & 0.4 & 0.0 & 7.4 & 3.6 & 4.8 \\
\hline & India & 20.2 & 21.7 & 35.8 & 55.0 & 64.0 & 170.3 & 994.1 & 1178.8 \\
\hline & Nepal & 0.2 & 7.4 & 10.0 & 17.8 & 11.8 & 1.5 & 3.9 & 14.3 \\
\hline & Pakistan & 42.3 & 23.2 & 26.5 & 28.8 & 46.5 & 70.1 & 137.7 & 73.4 \\
\hline & Maldives & 0.0 & 0.0 & 0.0 & 0.0 & 0.0 & 0.0 & 0.0 & 4.0 \\
\hline & Sri Lanka & 2.7 & 8.2 & 11.5 & 1.1 & 2.0 & 8.0 & 10.9 & 6.3 \\
\hline & Total & 62.7 & 52.4 & 72.5 & 102.0 & 124.2 & 257.3 & 1150.2 & 1278.2 \\
\hline \multirow[t]{6}{*}{ Sri Lanka } & Bangladesh & 2.7 & 9.8 & 12.0 & 5.7 & 2.4 & 8.9 & 6.0 & 1.2 \\
\hline & India & 30.0 & 20.2 & 32.0 & 45.9 & 76.7 & 118.0 & 469.0 & 630.3 \\
\hline & Maldives & 2.0 & 7.4 & 14.0 & 28.5 & 2.0 & 6.2 & 17.0 & 17.1 \\
\hline & Nepal & 0.0 & 0.1 & 0.0 & 2.0 & 0.0 & 0.0 & 1.0 & 5.4 \\
\hline & Pakistan & 55.5 & 32.5 & 43.0 & 31.3 & 17.8 & 50.8 & 52.0 & 104.6 \\
\hline & Total & 90.2 & 70.0 & 101.0 & 113.4 & 98.9 & 183.9 & 545.0 & 758.6 \\
\hline \multirow[t]{6}{*}{ Nepal } & Bangladesh & 10.7 & 0.6 & 3.5 & 9.6 & 0.2 & 15.2 & 11.0 & 5.9 \\
\hline & India & 40.5 & 14.8 & 25.0 & 145.5 & 87.4 & 58.5 & 117.8 & 439.7 \\
\hline & Pakistan & 2.0 & 0.7 & 0.5 & 0.8 & 0.1 & 2.1 & 3.3 & 6.2 \\
\hline & Maldives & 0.0 & 0.0 & 0.0 & 0.0 & 0.0 & 0.0 & 0.0 & 0.0 \\
\hline & Sri Lanka & 0.0 & 0.1 & 0.9 & 4.9 & 0.0 & 2.8 & 0.0 & 2.2 \\
\hline & Total & 53.2 & 16.2 & 29.9 & 160.8 & 87.7 & 78.6 & 132.1 & 454.0 \\
\hline \multirow[t]{6}{*}{ Maldives } & Bangladesh & 0.0 & 0.0 & 0.0 & 0.6 & 0.0 & 0.0 & 0.0 & 0.0 \\
\hline & India & 0.0 & 0.0 & 0.1 & 0.2 & 0.0 & 0.0 & 0.0 & 0.0 \\
\hline & Nepal & 0.0 & 0.0 & 0.0 & 0.0 & 0.0 & 0.0 & 0.0 & 0.0 \\
\hline & Pakistan & 0.3 & 0.0 & 0.0 & 0.1 & 0.2 & 0.7 & 0.7 & 2.0 \\
\hline & Sri Lanka & 1.8 & 7.2 & 11.2 & 15.5 & 2.2 & 9.5 & 15.3 & 31.4 \\
\hline & Total & 2.1 & 7.3 & 11.3 & 16.4 & 2.4 & 10.2 & 16.0 & 33.3 \\
\hline
\end{tabular}

Source: IMF Direction of Trade Statistics. 
Annex Table A3: South Asia: Profile of Dynamic Exports (1990-98)

\begin{tabular}{|c|c|c|c|c|c|c|c|}
\hline \multicolumn{8}{|c|}{ INDIA } \\
\hline Product Description & \begin{tabular}{|c|} 
Exports to \\
the ROW \\
$\left(\${ }^{\prime} 000\right)$
\end{tabular} & $\begin{array}{l}\text { Share in } \\
\text { Total } \\
\text { Exports }\end{array}$ & $\begin{array}{c}\text { Share } \\
\text { of } \\
\text { Growth }\end{array}$ & Product Description & $\begin{array}{l}\text { Intra-regional } \\
\text { Exports }\end{array}$ & $\begin{array}{l}\text { Share of } \\
\text { Intra- } \\
\text { regional } \\
\text { Exports }\end{array}$ & $\begin{array}{l}\text { Share of } \\
\text { Growth }\end{array}$ \\
\hline Diamonds, unworked cut/otherwise worked (6672) & 4745414 & 15.1 & 14.5 & Rice, milled (0423) & 540945 & 32.2 & 46.6 \\
\hline Cotton yarn & 989322 & 3.2 & 5.1 & Cotton yarn (6513) & 84585 & 5.0 & 4.2 \\
\hline Jewelry of gold, silver or platinum (8973) & 928068 & 3.0 & 5.1 & Medicaments n.e.s.(5429) & 51029 & 3.0 & 3.0 \\
\hline Rice, milled (0423) & 951132 & 3.0 & 4.7 & Woven cotton finish > 200g (6524) & 42546 & 2.5 & 2.8 \\
\hline UN Special Code (9310) & 746537 & 2.4 & 3.2 & Other coal (3212) & 32690 & 1.9 & 2.4 \\
\hline Crustaceans, frozen(0361) & 753242 & 2.4 & 2.3 & Oil-cake \& other residues (0813) & 35206 & 2.1 & 2.3 \\
\hline Jackets, blazers of textile fabrics (8424) & 472904 & 1.5 & 2.2 & Beans, peas, lentils \& leguminous vegetables (0542) & 23326 & 1.4 & 2.0 \\
\hline Men's/boys' shirts, woven & 718939 & 2.3 & 2.2 & UN Special Code (9310) & 24400 & 1.5 & 1.7 \\
\hline Organic chemicals, n.e.s. & 349150 & 1.1 & 2.2 & Motorcycles, auto-cycles and cycles (7851) & 27048 & 1.6 & 1.4 \\
\hline Curtains etc. n.e.s. (6585) & 509245 & 1.6 & 2.1 & Portland cement,slag cement etc.(6612) & 25681 & 1.5 & 1.3 \\
\hline T-shirts/singlets knit/c (8454) & 339698 & 1.1 & 2.0 & Synthetic organic dyestuffs (5311) & 22144 & 1.3 & 1.3 \\
\hline Women's/girls' blouse woven (8427) & 712770 & 2.3 & 1.5 & Chassis fitted with engines for MV(7841) & 25690 & 1.5 & 1.1 \\
\hline Coffee, whether or not roasted $(0711)$ & 330891 & 1.1 & 1.4 & Woven cotton finish < 200g (6523) & 18870 & 1.1 & 1.0 \\
\hline Non-magnetic recorded media (8987) & 203189 & 0.6 & 1.3 & Organic chemicals, n.e.s. & 13444 & 0.8 & 1.0 \\
\hline Special purpose cases (8319) & 180632 & 0.6 & 1.2 & Yarn of regenerated fibers (6518) & 11513 & 0.7 & 1.0 \\
\hline Insecticides packed for sale etc. (5911) & 191245 & 0.6 & 1.2 & Food wastes and prepared animal feeds (0819) & 11197 & 0.7 & 1.0 \\
\hline Other materials of vegetable origin (2929) & 207115 & 0.7 & 1.0 & Cotton fabrics, woven, bleached, dyed, printed (6522) & 31527 & 1.9 & 0.8 \\
\hline Synthetic organic dyestuffs (5311) & 310118 & 1.0 & 1.0 & Tyres, pneumatic, used on buses, lorries (6252) & 19465 & 1.2 & 0.8 \\
\hline Building \& monumental stone, worked (6613) & 181626 & 0.6 & 1.0 & & & & \\
\hline Edible nuts (0577) & 404608 & 1.3 & 1.0 & & & & \\
\hline Men's/boys' trousers etc. woven (8414) & 168868 & 0.5 & 1.0 & & & & \\
\hline Footwear leather upr n.e.s. (8514) & 296199 & 0.9 & 0.9 & & & & \\
\hline Men's/boys' knitted/crocheted shirts (8437) & 335441 & 1.1 & 0.9 & & & & \\
\hline Oil-cake \& other residues $(0813)$ & 425403 & 1.4 & 0.9 & & & & \\
\hline Carpets, rugs of textile materials (6596) & 136162 & 0.4 & 0.9 & & & & \\
\hline Woven cotton finish > 200g (6524) & 160951 & 0.5 & 0.8 & & & & \\
\hline Other made-up articles of textile (6589) & 177139 & 0.6 & 0.8 & & & & \\
\hline Insulin medicaments bulk (5421) & 146725 & 0.5 & 0.8 & & & & \\
\hline Women's/girls' skirts woven (8425) & 224274 & 0.7 & 0.8 & & & & \\
\hline Antibiotics n.e.s. not incl. in 541.7 (5413) & 127444 & 0.4 & 0.7 & & & & \\
\hline Castor oil (4225) & 142549 & 0.5 & 0.7 & & & & \\
\hline Yarn of regenerated fibers $(6518)$ & 131482 & 0.4 & 0.7 & & & & \\
\hline Pepper; pimento (0751) & 167489 & 0.5 & 0.7 & & & & \\
\hline Medicaments n.e.s. (5429) & 454180 & 1.4 & 0.7 & & & & \\
\hline Passenger motor vehicles excluding buses (7812) & 125382 & 0.4 & 0.7 & & & & \\
\hline Articles commonly used for domestic purposes (6974) & 135713 & 0.4 & 0.7 & & & & \\
\hline Fish, frozen (excluding fillets) & 137137 & 0.4 & 0.7 & & & & \\
\hline Other precious \& semi-precious stones (6673) & 201244 & 0.6 & 0.6 & & & & \\
\hline
\end{tabular}




\begin{tabular}{|c|c|c|c|c|c|c|c|}
\hline Product Description & \begin{tabular}{|c|} 
Exports to \\
the ROW \\
$\left(\${ }^{\prime} 000\right)$
\end{tabular} & $\begin{array}{l}\text { Share in } \\
\text { Total } \\
\text { Exports }\end{array}$ & $\begin{array}{c}\text { Share } \\
\text { of } \\
\text { Growth }\end{array}$ & Product Description & \begin{tabular}{|l} 
Intra-regional \\
Exports
\end{tabular} & $\begin{array}{l}\text { Share of } \\
\text { Intra- } \\
\text { regional } \\
\text { Exports }\end{array}$ & $\begin{array}{l}\text { Share of } \\
\text { Growth }\end{array}$ \\
\hline Women's/girls' underwear/nightwear woven (8428) & 108057 & 0.3 & 0.6 & & & & \\
\hline Tobacco, not stripped (1211) & 107119 & 0.3 & 0.6 & & & & \\
\hline Fabrics, woven of continuous materials (6531) & 165312 & 0.5 & 0.6 & & & & \\
\hline Women's/girls' trousers woven (8426) & 175955 & 0.6 & 0.6 & & & & \\
\hline Motor vehicles parts/accessories (7843) & 162457 & 0.5 & 0.6 & & & & \\
\hline $\begin{array}{l}\text { Articles of apparel \& clothing accessories, leather } \\
(8481)\end{array}$ & 396762 & 1.3 & 0.6 & & & & \\
\hline Tin plated/coated steel (6742) & 109600 & 0.3 & 0.6 & & & & \\
\hline Jerseys, pullovers, twinsets, cardigans (8451) & 93278 & 0.3 & 0.5 & & & & \\
\hline Bars \& rods of iron/steel (6732) & 82084 & 0.3 & 0.5 & & & & \\
\hline Other electrical machinery and equipment (7788) & 92109 & 0.3 & 0.5 & & & & \\
\hline Women's/girls underwear/nightwear k/c (8448) & 87921 & 0.3 & 0.5 & & & & \\
\hline Structures \& parts of iron/steel; plates (6911) & 82562 & 0.3 & 0.5 & & & & \\
\hline
\end{tabular}

Source: UN Comtrade via WITS

Notes: Column 2 and 6 represent exports to ROW and the Region in 1998, Column 3 and 7 the share of the total exports to each group and column 4 and 8 represent the share of growth each product from total growth to respective destinations, between 1990 to 1998 . 


\begin{tabular}{|c|c|c|c|c|c|c|c|}
\hline \multicolumn{8}{|c|}{ PAKISTAN } \\
\hline Product Description & $\begin{array}{c}\text { Exports to } \\
\text { the ROW } \\
\left(\${ }^{\prime} 000\right)\end{array}$ & \begin{tabular}{|c|} 
Share \\
in Total \\
Exports
\end{tabular} & $\begin{array}{c}\text { Share of } \\
\text { Growth }\end{array}$ & Product Description & \begin{tabular}{|l|} 
Intra- \\
regional \\
Exports
\end{tabular} & $\begin{array}{l}\text { Share of } \\
\text { Intra- } \\
\text { regional } \\
\text { Exports }\end{array}$ & $\begin{array}{l}\text { Share of } \\
\text { Growth }\end{array}$ \\
\hline Bed linen, table linen etc. (6584) & 1648699 & 10.0 & 13.6 & Refined sugars of refined beet/cane (0612) & 173491 & 42.4 & 65.8 \\
\hline Cotton fabrics, woven, bleached, dyed, printed (6522) & 1454561 & 8.8 & 12.4 & Potatoes, fresh or chilled, excluding sweet potatoes (0541) & 12042 & 2.9 & 4.6 \\
\hline Rice semi-milled or wholly milled (0422) & 1123210 & 6.8 & 9.3 & Cotton fabrics, woven, unbleached (6521) & 17177 & 4.2 & 3.6 \\
\hline Fabrics, woven of continuous textile materials (6531) & 1100756 & 6.7 & 7.9 & Rice semi-milled or wholly milled, broken rice(0422) & 21506 & 5.2 & 3.4 \\
\hline Undergarments, knitted, in synthetic fibers (8463) & 749086 & 4.6 & 7.2 & Other fresh or chilled vegetables(0545) & 8808 & 2.2 & 3.2 \\
\hline Articles of apparel \& clothing accessories, leather(8481) & 861488 & 5.2 & 4.8 & Fruit, fresh or dried, n.e.s. (0579) & 21822 & 5.3 & 2.3 \\
\hline Trousers, breeches etc. of textile fabrics (8423) & 432572 & 2.6 & 4.3 & Oil seeds and oleaginous fruit. n.e.s..(2238) & 5808 & 1.4 & 1.6 \\
\hline Other sporting goods and amusements (8947) & 513067 & 3.1 & 4.3 & Medicaments (including veterinary) (5417) & 5764 & 1.4 & 1.4 \\
\hline Cotton fabrics, woven, unbleached (6521) & 854337 & 5.2 & 4.1 & Fabrics, woven of synthetic materials (6531) & 11554 & 2.8 & 1.3 \\
\hline Refined sugars other products of refined beet/cane (0612) & 247719 & 1.5 & 3.5 & Cotton yarn (6513) & 15397 & 3.8 & 1.2 \\
\hline Outer garments \& clothing, knitted (8459) & 408056 & 2.5 & 3.2 & UN Special Code (9310) & 2540 & 0.6 & 1.0 \\
\hline Made-up articles of textile materials(6589) & 353315 & 2.1 & 2.7 & Cotton fabrics, woven, bleached. dyed, printed (6522) & 51318 & 12.5 & 0.7 \\
\hline Outer garments of textile fabrics (8429) & 135334 & 0.8 & 1.7 & Knitted/crocheted fabrics of fibers (6552) & 3111 & 0.8 & 0.6 \\
\hline Knitted/crocheted fabrics of non-synthetic fibers (6552) & 168498 & 1.0 & 1.7 & Durum wheat, unmilled (0411) & 1553 & 0.4 & 0.6 \\
\hline Undergarments, knitted in cotton (8462) & 155635 & 0.9 & 1.6 & Malt extract; preparations of flour etc, for infant food (0488) & 1541 & 0.4 & 0.6 \\
\hline Shirts, men's, of textile fabrics & 274122 & 1.7 & 1.5 & Articles \& manufact. of carving or molding materials (8991) & 1937 & 0.5 & 0.5 \\
\hline Yarn contain $85 \%$ by weight of synthetic fibers $(6514)$ & 116999 & 0.7 & 1.2 & Plants, seeds, fruit used in perfumery (2924) & 1833 & 0.4 & 0.5 \\
\hline Clothing accessories, knitted or crocheted (8472) & 148165 & 0.9 & 1.2 & Juices; fruit \& vegetables unfermented (0585) & 1219 & 0.3 & 0.5 \\
\hline Cotton yarn (6513) & 2034627 & 12.4 & 1.1 & Other tubes and pipes, of iron or steel (6783) & 1216 & 0.3 & 0.5 \\
\hline Medical instruments and appliances(8720) & 229334 & 1.4 & 1.1 & Apples, fresh (0574) & 1087 & 0.3 & 0.4 \\
\hline Yarn of discontinuous synthetic fibers $<85 \%(6516)$ & 68738 & 0.4 & 1.0 & Fish, frozen (excluding fillets)(0342) & 1080 & 0.3 & 0.4 \\
\hline Medicaments (including veterinary) (5417) & 64425 & 0.4 & 0.7 & Oranges,mandarins,clementines etc. (0571) & 1027 & 0.3 & 0.4 \\
\hline Articles \& manuf. of carving or molding (8991) & 89536 & 0.5 & 0.7 & Molasses, whether or not decolorized (0615) & 1155 & 0.3 & 0.4 \\
\hline Wadding textile fabrics (6577) & 84118 & 0.5 & 0.5 & Spices (except pepper and pimento)(0752) & 1241 & 0.3 & 0.3 \\
\hline Tarpaulins, sails, awnings, sunblinds etc. & 104479 & 0.6 & 0.5 & Elect. app.(switches, relays, fuses, plugs etc.) (7721) & 803 & 0.2 & 0.3 \\
\hline Footwear (8510) & 71615 & 0.4 & 0.4 & Tarpaulins, sails, awnings, sunblinds etc.(6582) & 981 & 0.2 & 0.3 \\
\hline Other outer garments of textile fabrics & 176585 & 1.1 & 0.4 & Medical instruments and appliances (8720) & 849 & 0.2 & 0.3 \\
\hline Fruit, fresh or dried, n.e.s. (0579) & 82213 & 0.5 & 0.4 & Machinery \& appliances for specialized industries (7284) & 970 & 0.2 & 0.2 \\
\hline Fish, frozen (excluding fillets) & 33359 & 0.2 & 0.3 & Tulle, lace, embroidery, ribbons etc. (6560) & 606 & 0.1 & 0.2 \\
\hline Molasses (0615) & 104340 & 0.6 & 0.3 & Sugar, confectionery \& preparations $(0620)$ & 639 & 0.2 & 0.2 \\
\hline Suits \& costumes of textile fabrics (8432) & 57622 & 0.4 & 0.3 & Miscellaneous articles of materials of div. 58 (8939) & 586 & 0.1 & 0.2 \\
\hline Cutlery & 36524 & 0.2 & 0.3 & Edible products and preparations n.e.s. (0980) & 553 & 0.1 & 0.2 \\
\hline Animal/vegetable oils \& fats, hydrogenated (4312) & 17402 & 0.5 & 0.2 & Bed linen, table linen, kitchen linen etc. (6584) & 1274 & 0.3 & 0.2 \\
\hline Clothing accessories of textile fabrics & 84306 & 0.5 & 0.2 & Pharmaceutical goods (5419) & 809 & 0.2 & 0.2 \\
\hline Sacks and bags of textile materials (6581) & 48950 & 0.3 & 0.2 & Other outer garments of textile fabrics (8429) & 378 & 0.1 & 0.1 \\
\hline Miscellaneous articles of materials of div. 58 (8939) & 20570 & 0.1 & 0.2 & Pebbles and crushed or broken stone (2734) & 444 & 0.1 & 0.1 \\
\hline Traveling rugs and blankets (6583) & 15708 & 0.1 & 0.2 & Electric insulating equipment (7732) & 350 & 0.1 & 0.1 \\
\hline Edible products and preparations, n.e.s. & 15520 & 0.1 & 0.2 & Building and monumental stone unworked (2731) & 415 & 0.1 & 0.1 \\
\hline
\end{tabular}




\begin{tabular}{|c|c|c|c|c|c|c|c|}
\hline Product Description & \begin{tabular}{|c|} 
Exports to \\
the ROW \\
$(\$, 000)$
\end{tabular} & \begin{tabular}{|c|} 
Share \\
in Total \\
Exports
\end{tabular} & $\begin{array}{l}\text { Share of } \\
\text { Growth }\end{array}$ & Product Description & \begin{tabular}{|l} 
Intra- \\
regional \\
Exports
\end{tabular} & $\begin{array}{l}\text { Share of } \\
\text { Intra- } \\
\text { regional } \\
\text { Exports }\end{array}$ & $\begin{array}{l}\text { Share of } \\
\text { Growth }\end{array}$ \\
\hline Other fresh or chilled vegetables & 19152 & 0.1 & 0.2 & Other parts \& accessories of motor vehicles(7849) & 556 & 0.1 & 0.1 \\
\hline Crustaceans and mollusks, frozen etc. (0360) & 167416 & 1.0 & 0.2 & Pens, pencils and fountain pens & 304 & 0.1 & 0.1 \\
\hline Shellac, seed lac, stick lac, resins, gum-resins etc. (2922) & 65450 & 0.4 & 0.2 & Gauze, cloth, grill of iron steel or copper (6935) & 279 & 0.1 & 0.1 \\
\hline Wheeled tractors, not incl. in 744.11(7224) & 11909 & 0.1 & 0.2 & Other electric power machinery, parts (7712) & 331 & 0.1 & 0.1 \\
\hline Potatoes, fresh or chilled (0541) & 13921 & 0.1 & 0.2 & Fish fillets, frozen (0344) & 254 & 0.1 & 0.1 \\
\hline Fish fillets, frozen $(0344)$ & 19569 & 0.1 & 0.1 & Wheeled tractors, not incl. in 744.11/783.2-(7224) & 270 & 0.1 & 0.1 \\
\hline Suits, men's, of textile fabrics (8422) & 44215 & 0.3 & 0.1 & Blooms, billets, slabs \& sheets of iron or steel (6725) & 235 & 0.1 & 0.1 \\
\hline Oranges, mandarins, clementines etc. (0571) & 14302 & 0.1 & 0.1 & Crustaceans and mollusks, fresh, frozen etc.(0360) & 406 & 0.1 & 0.1 \\
\hline Candles, matches, pyrophoric alloys etc. (8993) & 16490 & 0.1 & 0.1 & Other furniture and parts(8219) & 202 & 0.0 & 0.1 \\
\hline Juices; fruit \& vegetable, unfermented (0585) & 10803 & 0.1 & 0.1 & Macaroni, spaghetti and similar products(0483) & 198 & 0.0 & 0.1 \\
\hline Old clothing and other old textile articles (2690) & 12790 & 0.1 & 0.1 & Other sugars; sugar syrups; artificial honey (0619) & 231 & 0.1 & 0.1 \\
\hline Jewelry of gold, silver or platinum (8973) & 14709 & 0.1 & 0.1 & Varnishes and lacquers; distempers, water (5334) & 172 & 0.0 & 0.1 \\
\hline
\end{tabular}

\section{Source: UN Comtrade via WITS}

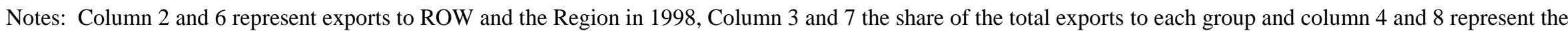
share of growth each product from total growth to respective destinations, between 1990 to 1998 . 


\begin{tabular}{|c|c|c|c|c|c|c|c|}
\hline \multicolumn{8}{|c|}{ BANGLADESH } \\
\hline Product Description & $\begin{array}{c}\text { Exports } \\
\text { to the } \\
\text { ROW } \\
\left(\${ }^{\prime} 000\right)\end{array}$ & \begin{tabular}{|c|} 
Share \\
in Total \\
Export \\
s \\
\end{tabular} & $\begin{array}{c}\text { Share } \\
\text { of } \\
\text { Growth }\end{array}$ & Product Description & $\begin{array}{l}\text { Intra-regional } \\
\text { Exports }\end{array}$ & $\begin{array}{l}\text { Share of } \\
\text { Intra- } \\
\text { regional } \\
\text { Exports }\end{array}$ & $\begin{array}{l}\text { Share of } \\
\text { Growth }\end{array}$ \\
\hline Men's/boys shirts, woven (8415) & 899130 & 17.9 & 21.3 & Jute \& other textile based fibers, n.e.s. (2640) & 20977 & 46.6 & 33.8 \\
\hline Jerseys/pullovers etc. (8453) & 394212 & 7.9 & 11.4 & Other inorganic bases \& metallic oxides, hydroxides.(5225) & & 10.1 & 33.7 \\
\hline T-shirts/singlets knit/c (8454) & 377689 & 7.5 & 10.8 & Tea (0741) & 9770 & 21.7 & 7.0 \\
\hline Men's/boys' jackets/blazer woven (8413) & 376115 & 7.5 & 10.3 & Lifting, handling, loading machines, conveyors (7442) & 585 & 1.3 & 4.3 \\
\hline Men's/boys' trouser etc. woven (8414) & 411904 & 8.2 & 10.3 & Crustaceans and molluscs, fresh, chilled etc.(0360) & & 1.1 & 3.8 \\
\hline Men's/boys' coats, woven(8411) & 332233 & 6.6 & 7.5 & Vegetable material used primarily for plaiting (2923) & 366 & 0.8 & 2.6 \\
\hline Women's/girls blouse woven(8427) & 172584 & 3.4 & 3.6 & Sheets \& plates, rolled (of less than $3 \mathrm{~mm}$ ) (6746) & & 0.6 & 2.1 \\
\hline Women/girls' trousers woven(8426) & 148928 & 3.0 & 3.6 & Other artificial plastic materials, n.e.s. (5852) & & 0.4 & 1.5 \\
\hline Crustaceans, frozen(0361) & 257502 & 5.1 & 3.2 & Casks, drums, boxes of iron/steel for packing (6924) & 171 & 0.4 & 1.1 \\
\hline Trousers, breeches etc. of textile fabrics (8423) & 110937 & 2.2 & 2.8 & Fabrics, woven, of synthetic fibers (6534) & & 0.3 & 1.0 \\
\hline Overcoats and other coats, men's (8421) & 105758 & 2.1 & 2.3 & Cotton yarn (6513) & & 0.3 & 1.0 \\
\hline Suits \& costumes of textile fabrics (8432) & 45566 & 0.9 & 1.4 & Fabrics, woven, of jute or textile based fiber (6545) & 209 & 0.5 & 0.7 \\
\hline Cotton fabrics, woven, unbleached, not mercerized(6521) & 49231 & 1.0 & 1.3 & Articles \& manufactures of carving or molding materials(8991) & & 0.2 & 0.7 \\
\hline Women's/girls' underwear/nightwear woven (8428) & 46164 & 0.9 & 1.3 & Jackets, blazers of textile fabrics (8424) & & 0.2 & 0.6 \\
\hline Tarpaulins, sails, awnings, sunblinds tents etc.(6582) & 41186 & 0.8 & 1.2 & Fuel oils, n.e.s. (3344) & 130 & 0.3 & 0.6 \\
\hline $\begin{array}{l}\text { Twine, cordage, ropes \& cables \& manufacture thereof } \\
(65750)\end{array}$ & 49887 & 1.0 & 1.2 & Electrical motors \& generators, generating sets (7162) & 71 & 0.2 & 0.5 \\
\hline Jerseys, pullovers, twinsets, cardigans knitted (8451) & 38744 & 0.8 & 1.1 & Under garments, knitted in cotton (8462) & & 0.2 & 0.5 \\
\hline Men/boy knitted/crocheted shirts (8437) & 41771 & 0.8 & 0.9 & Shirts, men's, of textile fabrics (8441) & 82 & 0.2 & 0.5 \\
\hline Fabrics, woven, of discontinuous synthetic fibers (6534) & 29686 & 0.6 & 0.9 & Blouses of textile fabrics (8435) & & 0.1 & 0.4 \\
\hline Men's/boys; underwear/nightwear, woven (8416) & 35437 & 0.7 & 0.9 & Soap; organic products \& preparations (5541) & & 0.1 & 0.3 \\
\hline Swimwear(8456) & 28901 & 0.6 & 0.8 & Fish, frozen (excluding fillets) & 46 & 0.1 & 0.3 \\
\hline Mineral or chemical fertilizers, nitrogenous (5621) & 32920 & 0.7 & 0.7 & Miscellaneous articles of materials of div. (8939) & 70 & 0.2 & 0.3 \\
\hline Under garments, excl. shirts, of textile fabrics (8442) & 42488 & 0.8 & 0.6 & Refractory bricks \& other refractory construction (6623) & & 0.1 & 0.3 \\
\hline Yarn of text. fibers, incl. yarn of glass fiber (6519) & 58950 & 1.2 & 0.5 & Coats and jackets of textile fabrics (8431) & & 0.1 & 0.3 \\
\hline Sacks and bags, of textile materials (6581) & 89894 & 1.8 & & Auxiliary machinery for headings $724.51 / 52 / 53 / 61(7246)$ & 45 & 0.1 & 0.2 \\
\hline Jute/based fiber, raw/rett. (2641) & 61652 & 1.2 & & Other outer garments \& clothing, knitted (8459) & & 0.1 & 0.2 \\
\hline Leather of other bovine cattle and leather (6114) & 82080 & 1.6 & & Small-wares and toilet articles, dusters etc.(8998) & & 0.1 & 0.2 \\
\hline \multirow[t]{2}{*}{ Fabrics, woven, of jute \& other textile based. fiber (6545) } & 72116 & 1.4 & & Edible products and preparations, n.e.s. (0980) & 45 & 0.1 & 0.2 \\
\hline & & & & Agricultural \& horticultural machinery for soil preparation (7211) & & 0.1 & 0.2 \\
\hline
\end{tabular}

Source: UN Comtrade via WITS

Notes: Column 2 and 6 represent exports to ROW and the Region in 1998, Column 3 and 7 the share of the total exports to each group and column 4 and 8 represent the share of growth each product from total growth to respective destinations, between 1990 to 1998. 


\begin{tabular}{|c|c|c|c|c|c|c|c|}
\hline \multicolumn{8}{|c|}{ SRI LANKA } \\
\hline Product Description & $\begin{array}{l}\text { Exports } \\
\text { to the } \\
\text { ROW } \\
(\$, 000)\end{array}$ & \begin{tabular}{|c|} 
Share \\
in Total \\
Exports
\end{tabular} & $\begin{array}{l}\text { Share of } \\
\text { Growth }\end{array}$ & Product Description & $\begin{array}{l}\text { Intra- } \\
\text { regional } \\
\text { Exports }\end{array}$ & \begin{tabular}{|} 
Share of Intra- \\
regional \\
Exports
\end{tabular} & $\begin{array}{l}\text { Share of } \\
\text { Growth }\end{array}$ \\
\hline Tea (0741) & 1213323 & 14.0 & 4.5 & Knitted/crocheted fabrics of fibers (6552) & 9646 & 7.6 & 12.0 \\
\hline Other outer garments of textile fabrics (8439) & 610120 & 7.0 & 9.0 & Pepper; pimento(0751) & 10377 & 8.2 & 11.6 \\
\hline Under garments, knitted in cotton (8462) & 556127 & 6.4 & 9.4 & Copra (2231) & 8855 & 7.0 & 7.4 \\
\hline Blouses of textile fabrics (8435) & 420206 & 4.8 & 4.9 & Tulle, lace, embroidery, ribbons,\& wares (6560) & 4855 & 3.9 & 6.0 \\
\hline Trousers, breeches etc. of textile fabrics (8423) & 351763 & 4.1 & 4.2 & Edible nuts (0577) & 8391 & 6.7 & 5.3 \\
\hline Other outer garments \& clothing, knitted(8459) & 349862 & 4.0 & 4.5 & Spices (except pepper and pimento) (0752) & 5052 & 4.0 & 5.0 \\
\hline Shirts, men's, of textile fabrics (8441) & 301305 & 3.5 & 3.4 & Fruit, fresh or dried, n.e.s. (0579) & 4434 & 3.5 & 5.0 \\
\hline Travel goods, handbags, briefcases etc. (8310) & 246126 & 2.8 & 4.6 & Cotton fabrics, woven, bleached, dyed, printed (6522) & 4320 & 3.4 & 4.8 \\
\hline Jerseys, pullovers, twinsets, cardigans (8451) & 223113 & 2.6 & 3.2 & Warships of all kinds (7931) & 3081 & 2.4 & 3.8 \\
\hline Dresses, women's, of textile fabrics (8433) & 198962 & 2.3 & 2.8 & Articles of apparel \& clothing accessories of plastic (84820 & 2927 & 2.3 & 3.7 \\
\hline Jackets, blazers of textile fabrics (8424) & 192930 & 2.2 & 2.2 & Waste paper, paperboard; for paper-making (2511) & 2709 & 2.1 & 3.3 \\
\hline Parts of and accessories suitable for (7599) & 175139 & 2.0 & 3.2 & Acyclic alcohols \& their derivatives (5121) & 2570 & 2.0 & 2.7 \\
\hline Corsets, brassieres, suspenders etc. (8465) & 170894 & 2.0 & 3.0 & Yarn containing $85 \%$ by weight of synthetic fibers (6514) & 1638 & 1.3 & 2.0 \\
\hline Skirts, women's, of textile fabrics (8434) & 160455 & 1.9 & 2.3 & Tugs, special purpose vessels, floating structures (7938) & 1445 & 1.1 & 1.8 \\
\hline Edible nuts (excluding those extracted of oil) (0577) & 159539 & 1.8 & 1.3 & Other fresh or chilled vegetables (0545) & 2271 & 1.8 & 1.7 \\
\hline Coats and jackets of textile fabrics(8431) & 155015 & 1.8 & 1.2 & Bones, horns, hooves, claws, coral, shells etc. (2911) & 1308 & 1.0 & 1.4 \\
\hline Other tyres, tyre cases, inner tubes (6259) & 137954 & 1.6 & 2.0 & Printed matter, n.e.s. (8928) & 1104 & 0.9 & 1.3 \\
\hline Undergarments, women's, of textile fabrics (8443) & 137110 & 1.6 & 2.1 & Fabrics, woven of synthetic textile materials (6531) & 858 & 0.7 & 1.1 \\
\hline Footwear (8510) & 133707 & 1.5 & 2.1 & Clothing accessories of textile fabrics (8471) & 730 & 0.6 & 0.9 \\
\hline Clothing accessories, knitted or crocheted (8472) & 130340 & 1.5 & 1.7 & Cotton fabrics, woven, unbleached (6521) & 667 & 0.5 & 0.8 \\
\hline Articles of apparel \& clothing of plastic (8482) & 120406 & 1.4 & 1.9 & Non-refractory ceramic bricks, tiles, pipes (6624) & 884 & 0.7 & 0.7 \\
\hline Spices (except pepper and pimento) (0752) & 117757 & 1.4 & 0.9 & Miscellaneous articles of base metal (6996) & 497 & 0.4 & 0.6 \\
\hline Undergarments, knitted, of synthetic fibers (8463) & 111254 & 1.3 & 0.7 & & & & \\
\hline Tarpaulins, sails, awnings, sunblinds etc.(6582) & 106302 & 1.2 & 1.8 & & & & \\
\hline Children's toys, indoor games etc. (8942) & 81259 & 0.9 & 1.5 & & & & \\
\hline Crustaceans and molluscs, fresh, frozen (0360) & 81134 & 0.9 & 0.8 & & & & \\
\hline Other outer garments of textile fabrics (8429) & 77784 & 0.9 & 0.8 & & & & \\
\hline Dresses, skirts, suits etc, knitted or crocheted (8452) & 70880 & 0.8 & 0.8 & & & & \\
\hline Vegetable textile fibers, n.e.s. and waste (2659) & 66171 & 0.8 & 0.6 & & & & \\
\hline Tableware etc. of porcelain or china (6664) & 50358 & 0.6 & 0.7 & & & & \\
\hline Headgear and fittings thereof, n.e.s.(8484) & 47894 & 0.6 & 0.9 & & & & \\
\hline Fish, fresh (live/dead) or chilled, excl. fillets (0341) & 43815 & 0.5 & 0.7 & & & & \\
\hline Other articles of rubber, n.e.s. (62890) & 40140 & 0.5 & 0.5 & & & & \\
\hline Suits \& costumes of textile fabrics (8432) & 39253 & 0.5 & 0.5 & & & & \\
\hline Basketwork, wickerwork etc. (8997) & 37308 & 0.4 & 0.4 & & & & \\
\hline Articles for the conveyance or packing of goods (8931) & 36038 & 0.4 & 0.4 & & & & \\
\hline Overcoats and other coats, men's (8421) & 33992 & 0.4 & 0.3 & & & & \\
\hline Other electric power machinery, parts of (7712) & 31652 & 0.4 & 0.6 & & & & \\
\hline Cotton fabrics, woven, bleach. dyed, printed (6522) & 31458 & 0.4 & 0.6 & & & & \\
\hline
\end{tabular}




\begin{tabular}{|c|c|c|c|c|c|c|c|}
\hline Product Description & $\begin{array}{l}\text { Exports } \\
\text { to the } \\
\text { ROW } \\
(\$ 000)\end{array}$ & \begin{tabular}{|c|} 
Share \\
in Total \\
Exports
\end{tabular} & $\begin{array}{l}\text { Share of } \\
\text { Growth }\end{array}$ & Product Description & $\begin{array}{c}\text { Intra- } \\
\text { regional } \\
\text { Exports }\end{array}$ & \begin{tabular}{|c|} 
Share of Intra- \\
regional \\
Exports
\end{tabular} & $\begin{array}{l}\text { Share of } \\
\text { Growth }\end{array}$ \\
\hline Bed linen, table linen, toilet \& kitchen linen (6584) & 30987 & 0.4 & 0.4 & & & & \\
\hline Cotton fabrics, woven, unbleached (6521) & 30633 & 0.4 & 0.6 & & & & \\
\hline Undergarments, excluding shirts of textile fabrics (8442) & 29750 & 0.3 & 0.5 & & & & \\
\hline Pepper; pimento (0751) & 27140 & 0.3 & 0.4 & & & & \\
\hline Statuettes \& other ornaments \& articles (6666) & 26157 & 0.3 & 0.4 & & & & \\
\hline Transformers, electrical (7771) & 22495 & 0.3 & 0.4 & & & & \\
\hline Printed circuits and parts thereof (7722) & 21900 & 0.3 & 0.4 & & & & \\
\hline Non-synthetic knitted/crocheted fabrics (6552) & 21818 & 0.3 & 0.3 & & & & \\
\hline Sacks and bags of textile materials (6581) & 21006 & 0.2 & 0.4 & & & & \\
\hline Other non-electrical mach. amp. parts(7452) & 19093 & 0.2 & 0.4 & & & & \\
\hline Fabrics, woven containing $85 \%$ synthetic fibers (6532) & 17385 & 0.2 & 0.3 & & & & \\
\hline
\end{tabular}

Source: UN Comtrade via WITS

Notes: Column 2 and 6 represent exports to ROW and the Region in 1998, Column 3 and 7 the share of the total exports to each group and column 4 and 8 represent the share of growth each product from total growth to respective destinations, between 1990 to 1998 . 


\begin{tabular}{|c|c|c|c|c|c|c|c|}
\hline \multicolumn{8}{|c|}{ NEPAL } \\
\hline Product Description & $\begin{array}{l}\text { Exports } \\
\text { to the } \\
\text { ROW } \\
\left(\${ }^{\prime} 000\right)\end{array}$ & \begin{tabular}{|c|} 
Share \\
in Total \\
Exports
\end{tabular} & $\begin{array}{l}\text { Share of } \\
\text { Growth }\end{array}$ & Product Description & $\begin{array}{l}\text { Intra- } \\
\text { regional } \\
\text { Exports }\end{array}$ & $\begin{array}{l}\text { Share of Intra- } \\
\text { regional } \\
\text { Exports }\end{array}$ & $\begin{array}{l}\text { Share of } \\
\text { Growth }\end{array}$ \\
\hline Carpeting and rugs, knotted (6592) & 257858 & 48.6 & 69.9 & Beans, peas, lentils \& other vegetables (0542) & 12486 & 85.7 & 82.7 \\
\hline Garments of textile fabrics (8439) & 39643 & 7.5 & 6.8 & Rice, milled(0423) & 1603 & 11.0 & 13.9 \\
\hline UN Special Code (9310) & 18443 & 3.5 & 5.0 & Other wheat and meslin, unmilled (0412) & 134 & 0.9 & 1.2 \\
\hline Trousers,breeches etc. (8423) & 28797 & 5.4 & 3.9 & UN Special Code (9310) & 82 & 0.6 & 0.7 \\
\hline Bed table, toilet \& kitchen linen (6584) & 8129 & 1.5 & 2.2 & Building and monumental stone unworked (2731) & 59 & 0.4 & 0.5 \\
\hline Blouses of textile fabrics (8435) & 15600 & 2.9 & 2.1 & Copper wire (6824) & 27 & 0.2 & 0.2 \\
\hline Undergarments, knitted in cotton (8462) & 6675 & 1.3 & 1.8 & Auxiliary plant for use with boilers (7112) & 23 & 0.2 & 0.2 \\
\hline Ornamental objects of mat. of div.58 (8933) & 6430 & 1.2 & 1.7 & Macaroni, spaghetti and similar products & 24 & 0.2 & 0.2 \\
\hline Jewelry of gold, silver or platinum (8973) & 4820 & 0.9 & 1.3 & Oral hygiene preparation (5534) & 12 & 0.1 & 0.1 \\
\hline Oil seeds and oleaginous fruit (2238) & 3963 & 0.7 & 1.1 & Beer made from malt (including ale, stout) (1123) & 11 & 0.1 & 0.1 \\
\hline Other outer garments \& clothing, knitted (8459) & 2932 & 0.6 & 0.8 & Copper tube/pipe/fitting (6827) & 10 & 0.1 & 0.1 \\
\hline Beans,peas,lentils \& vegetables (0542) & 13842 & 2.6 & 0.7 & Yarn contain. $85 \%$ by weight of synthetic fibers (6514) & 8 & 0.1 & 0.1 \\
\hline Articles of paper pulp, paper, paperboard, cellulose (6428) & 2316 & 0.4 & 0.6 & Optical appliances, n.e.s. & 6 & 0.0 & 0.0 \\
\hline Jerseys, pullovers, twinsets, cardigans (8451) & 3371 & 0.6 & 0.6 & Bulbs, tubers \& rhizomes of flowering etc.(2926) & 7 & 0.0 & 0.0 \\
\hline Jackets, blazers of textile fabrics (8424) & 1417 & 0.3 & 0.3 & Animal leather n.e.s. & 2 & 0.0 & 0.0 \\
\hline Clothing accessories of textile fabrics (8471) & 1252 & 0.2 & 0.3 & Animal/vegetable oils \& fats,(hydrogenated) (4312) & 1 & 0.0 & 0.0 \\
\hline Travel goods, handbags, purses, sheaths (8310) & 1349 & 0.3 & 0.3 & Original sculpture etc. & 1 & 0.0 & 0.0 \\
\hline Leather apparel \& clothing accessories (8481) & 677 & 0.1 & 0.2 & Live animals used for food (0019) & 1 & & 0.0 \\
\hline Manufactured articles of wood, n.e.s. (6359) & 409 & 0.1 & 0.1 & Bakery products (e.g. bread, biscuits) etc..(0484) & 1 & 0.0 & 0.0 \\
\hline Clothing accessories, knitted or crocheted (8472) & 258 & 0.0 & 0.1 & Gypsum, plasters, limestone stone etc. (2732) & 0 & & 0.0 \\
\hline Tea (0741) & 356 & 0.1 & 0.1 & Paper products n.e.s. (6429) & 0 & & 0.0 \\
\hline Toilet articles, feather dusters (8998) & 254 & 0.0 & 0.1 & Men's/boys' coats, woven & 0 & & 0.0 \\
\hline Natural honey $(0616)$ & 140 & 0.0 & 0.0 & Cotton seeds (2223) & 0 & 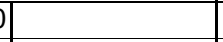 & 0.0 \\
\hline Fabrics, woven, of silk, of noil or waste silk (6541) & 95 & 0.0 & 0.0 & Jute/based fibre, raw/rett (2641) & 0 & | & 0.0 \\
\hline Beer made from malt (1123) & 74 & 0.0 & 0.0 & Trunks/suitcases/etc. (8312) & 0 & ] & 0.0 \\
\hline Cotton fabrics, woven, bleached, dyed, printed (6522) & 46 & 0.0 & 0.0 & & & & \\
\hline Armored vehicles, arms of war \& ammunition (9510) & 38 & 0.0 & 0.0 & & & & \\
\hline Manufactures of wood use (6354) & 33 & 0.0 & 0.0 & & & & \\
\hline Bulbs, tubers \& rhizomes of flowering etc. (2926) & 31 & 0.0 & 0.0 & & & & \\
\hline Macaroni, spaghetti and similar products (0483) & 24 & 0.0 & 0.0 & & & & \\
\hline Coffee, whether or not roasted (0711) & 10 & 0.0 & 0.0 & & & & \\
\hline Vegetables, prepared or preserved, n.e.s. (0565) & 6 & 0.0 & 0.0 & & & & \\
\hline Medicaments (including veterinary) (5417) & 57 & 0.0 & 0.0 & & & & \\
\hline Gramophone records and thereof (8983) & 5 & 0.0 & 0.0 & & & & \\
\hline Food wastes and animal feeds, n.e.s. (0819) & 1 & 0.0 & & & & & \\
\hline Shellac, seed lac, stick lac, resins, gum-resins (2922) & 1 & 0.0 & & & & & \\
\hline Vegetable products, roots \& tubers (0548) & 7 & 0.0 & & & & & \\
\hline Tarpaulins, sails, sunblinds, tents etc. (6582) & 1 & 0.0 & & & & & \\
\hline Cotton seeds (2223) & 0 & 0.0 & & & & & \\
\hline
\end{tabular}




\begin{tabular}{|c|c|c|c|c|c|c|}
\hline Product Description & $\begin{array}{c}\text { Exports } \\
\text { to the } \\
\text { ROW } \\
\left(\${ }^{\prime} 000\right)\end{array}$ & $\mid \begin{array}{c}\text { Share } \\
\text { in Total } \\
\text { Exports }\end{array}$ & $\begin{array}{l}\text { Share of } \\
\text { Growth }\end{array}$ & $\begin{array}{c}\text { Intra-regional } \\
\text { Exports }\end{array}$ & \begin{tabular}{|c|} 
Share of \\
Intra-regional \\
Exports
\end{tabular} & $\begin{array}{l}\text { Share of } \\
\text { Growth }\end{array}$ \\
\hline Spirits; liqueurs, other spirits, n.e.s. (1124) & 1 & 0.0 & & & & \\
\hline Building \& monumental stone, worked (6613) & 1 & 0.0 & & & & \\
\hline Printed matter, n.e.s..(8928) & 4 & 0.0 & & & & \\
\hline Seeds, fruit \& spores (kind used for sowing) (2925) & 28 & 0.0 & & & & \\
\hline Pianos and string musical instruments (8981) & 0 & 0.0 & & & & \\
\hline Children's toys, indoor games etc. (8942) & 0 & 0.0 & & & & \\
\hline Wood and resin-based chemical products (5981) & 0 & 0.0 & & & & \\
\hline Other fresh or chilled vegetables (0545) & 17 & 0.0 & & & & \\
\hline Miscellaneous articles of materials (8939) & 1 & 0.0 & & & & \\
\hline Footwear (8510) & 7 & 0.0 & & & & \\
\hline
\end{tabular}

Source: UN Comtrade via WITS

Notes: Column 2 and 6 represent exports to ROW and the Region in 1998, Column 3 and 7 the share of the total exports to each group and column 4 and 8 represent the share of growth each product from total growth to respective destinations, between 1990 to 1998. 

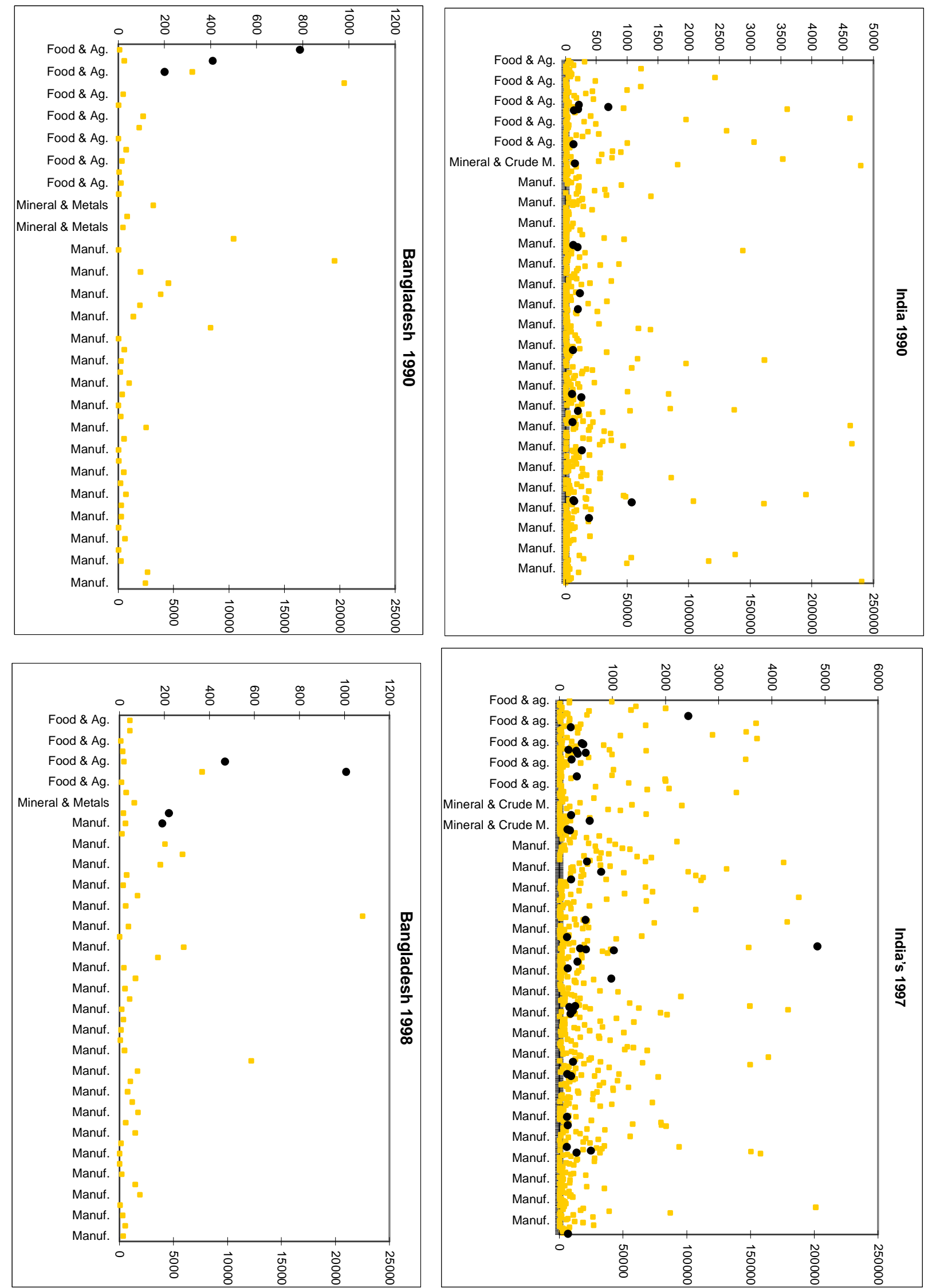

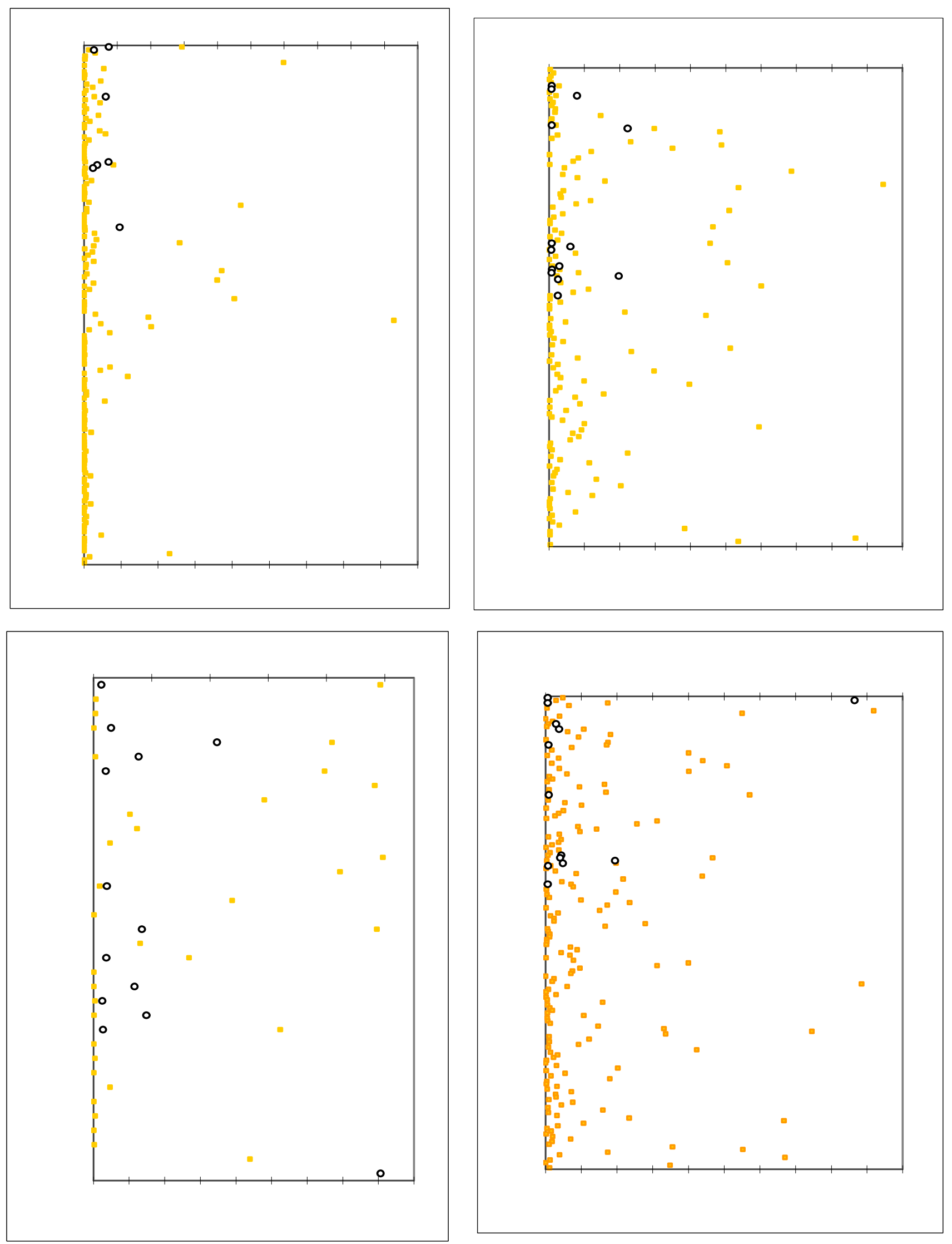
Annex Table A4:

Competition between South Asian Countries: Observation of Similarity among Major Exports (1998)

\begin{tabular}{|c|c|c|c|c|c|}
\hline \multicolumn{6}{|c|}{ INDIA } \\
\hline Product Description & SITC & \begin{tabular}{|c|} 
Exports to the \\
ROW $\left(\${ }^{\prime} 000\right)$
\end{tabular} & $\begin{array}{l}\text { Share in } \\
\text { Exports }\end{array}$ & RCA & Similarity count $^{2}$ \\
\hline Diamonds, unworked cut/otherwise worked, not mounted/set & 6672 & 4745414 & 15.1 & 23.9 & 2 \\
\hline Cotton yarn & 6513 & 989322 & 3.2 & 23.3 & 2 \\
\hline Rice, milled & 0423 & 951132 & 3.0 & 20.2 & \\
\hline Jewelry of gold, silver or platinum & 8973 & 928068 & 3.0 & 7.9 & 2 \\
\hline Crustaceans, frozen & 0361 & 753242 & 2.4 & 13.6 & \\
\hline UN Special Code & 9310 & 746537 & 2.4 & 0.8 & 4 \\
\hline Men's/boys' shirts, woven & 8415 & 718939 & 2.3 & 12.8 & \\
\hline Women's/girls' blouse woven & 8427 & 712770 & 2.3 & 17.4 & \\
\hline Curtains etc n.e.s. & 6585 & 509245 & 1.6 & 34.5 & \\
\hline Jackets, blazers of textile fabrics & 8424 & 472904 & 1.5 & 21.5 & 5 \\
\hline Medicaments n.e.s. & 5429 & 454180 & 1.4 & 1.4 & \\
\hline Oil-cake \& other residues (except dregs) & 0813 & 425403 & 1.4 & 8.0 & \\
\hline Edible nuts (excl. nuts used for the extraction of oil) & 0577 & 404608 & 1.3 & 16.5 & 2 \\
\hline Articles of apparel \& clothing accessories, of leather & 8481 & 396762 & 1.3 & 13.0 & 3 \\
\hline Organic chemicals, n.e.s. & 5169 & 349150 & 1.1 & 19.1 & \\
\hline T-shirts/singlets knit/c & 8454 & 339698 & 1.1 & 4.5 & \\
\hline Men's/boys' knitted/crocheted shirts & 8437 & 335441 & 1.1 & 12.7 & \\
\hline Coffee, whether or not roasted or freed of caffeine & 0711 & 330891 & 1.1 & 5.6 & 2 \\
\hline Synthetic organic dyestuffs & 5311 & 310118 & 1.0 & 5.5 & \\
\hline Footwear leather upr, n.e.s. & 8514 & 296199 & 0.9 & 2.4 & \\
\hline Womens/girl skirts woven & 8425 & 224274 & 0.7 & 11.7 & \\
\hline Other materials of vegetable origin, n.e.s. & 2929 & 207115 & 0.7 & 15.3 & \\
\hline Non-magnetic recorded media & 8987 & 203189 & 0.6 & 2.1 & \\
\hline Other precious \& semi-precious stones, unworked, cut etc. & 6673 & 201244 & 0.6 & 22.4 & 2 \\
\hline Insecticides packed for sale etc. & 5911 & 191245 & 0.6 & 10.1 & \\
\hline Building \& monumental stone, worked,\& articles thereof & 6613 & 181626 & 0.6 & 5.8 & \\
\hline Special purpose cases & 8319 & 180632 & 0.6 & 7.8 & \\
\hline Other made-up articles of textile materials, n.e.s.. & 6589 & 177139 & 0.6 & 9.9 & 2 \\
\hline Women's/girls' trousers woven & 8426 & 175955 & 0.6 & 2.7 & \\
\hline Men's/boys' trousers etc. woven & 8414 & 168868 & 0.5 & 1.8 & \\
\hline Pepper ; pimento & 0751 & 167489 & 0.5 & 21.5 & 2 \\
\hline Fabrics, woven of continuous synthetic textile materials & 6531 & 165312 & 0.5 & 1.8 & 2 \\
\hline Motor vehicle parts/accessories n.e.s. & 7843 & 162457 & 0.5 & 0.2 & \\
\hline Woven cotton finish $>200 \mathrm{~g}$ & 6524 & 160951 & 0.5 & 4.1 & \\
\hline Insulin medicaments bulk & 5421 & 146725 & 0.5 & 2.9 & \\
\hline Castor oil & 4225 & 142549 & 0.5 & 119.3 & \\
\hline Fish, frozen (excluding fillets) & 0342 & 137137 & 0.4 & 3.2 & 3 \\
\hline Carpets, rugs etc. of other textile materials n.e.s. & 6596 & 136162 & 0.4 & 19.9 & \\
\hline Articles commonly used for domestic purposes, pot scourers & 6974 & 135713 & 0.4 & 4.3 & \\
\hline Yarn of regenerated fibers, put up for retail sale & 6518 & 131482 & 0.4 & 4.0 & \\
\hline Antibiotics n.e.s. not incl. in 541.7 & 5413 & 127444 & 0.4 & 3.0 & \\
\hline Passenger motor vehicles excluding buses & 7812 & 125382 & 0.4 & 0.1 & \\
\hline Tin plated/coated steel & 6742 & 109600 & 0.3 & 4.7 & \\
\hline Women's/girls' underwear/nightwear, woven & 8428 & 108057 & 0.3 & 7.9 & \\
\hline Tobacco, not stripped & 1211 & 107119 & 0.3 & 9.8 & 2 \\
\hline Jerseys, pullovers, twinsets, cardigans, knitted & 8451 & 93278 & 0.3 & 4.2 & 4 \\
\hline Other electrical machinery and equipment & 7788 & 92109 & 0.3 & 0.9 & \\
\hline Women's/girls' underwear/nightwear k/c & 8448 & 87921 & 0.3 & 2.6 & \\
\hline Structures \& parts of structures; iron/steel; plates & 6911 & 82562 & 0.3 & 1.2 & \\
\hline Bars \& rods, of iron/steel; hollow mining drill steel & 6732 & 82084 & 0.3 & 0.7 & \\
\hline
\end{tabular}

Source: WITS Database, World Bank

Notes: ${ }^{1}$ Percentage share of product in total exports (1998), ${ }^{2}$ Number of South Asian countries exporting the product to ROW with RCA>1 


\begin{tabular}{|c|c|c|c|c|c|}
\hline \multicolumn{6}{|c|}{ PAKISTAN } \\
\hline Product Description & SITC & $\begin{array}{l}\text { Exports to the } \\
\text { ROW (\$'000) }\end{array}$ & $\begin{array}{l}\text { Share in } \\
\text { Exports }\end{array}$ & RCA & Similarity count $^{2}$ \\
\hline Cotton yarn & 6513 & 2034627 & 13.0 & 183.7 & 2 \\
\hline Bed linen, table linen, toilet \& kitchen linen etc. & 6584 & 1648699 & 10.6 & 136.1 & 4 \\
\hline Cotton fabrics, woven, bleach.mercerized, dyed, printed & 6522 & 1454561 & 9.3 & 55.2 & 4 \\
\hline Rice semi-milled or wholly milled, broken rice & 0422 & 1123210 & 7.2 & 93.5 & \\
\hline Fabrics, woven of continuous synthetic textile materials & 6531 & 1100756 & 7.0 & 47.5 & 2 \\
\hline Articles of apparel \& clothing accessories, of leather & 8481 & 861488 & 5.5 & 103.0 & 3 \\
\hline Cotton fabrics, woven, unbleached, not mercerized & 6521 & 854337 & 5.5 & 139.0 & 2 \\
\hline Under garments, knitted, of synthetic fibers & 8463 & 749086 & 4.8 & 105.5 & 3 \\
\hline Other sporting goods and fairground amusements & 8947 & 513067 & 3.3 & 35.1 & 2 \\
\hline Trousers, breeches etc. of textile fabrics & 8423 & 432572 & 2.8 & 18.2 & 4 \\
\hline Carpets, carpeting and rugs, knotted & 6592 & 408703 & 2.6 & 206.0 & 2 \\
\hline Other outer garments \& clothing, knitted & 8459 & 408056 & 2.6 & 14.6 & 4 \\
\hline Other made-up articles of textile materials, n.e.s. & 6589 & 353315 & 2.3 & 52.5 & 2 \\
\hline Shirts, men's, of textile fabrics & 8441 & 274122 & 1.8 & 14.8 & 3 \\
\hline Refined sugars and other products of refined beet/cane & 0612 & 247719 & 1.6 & 25.0 & \\
\hline Medical instruments and appliances & 8720 & 229334 & 1.5 & 6.6 & \\
\hline Leather of other hides or skins & 6116 & 189679 & 1.2 & 90.1 & 2 \\
\hline Other outer garments of textile fabrics & 8439 & 176585 & 1.1 & 5.4 & 4 \\
\hline Knitted/crocheted fabrics of fibers other than synthetic & 6552 & 168498 & 1.1 & 8.0 & \\
\hline Crustaceans and mollusks, fresh, chilled, frozen etc. & 0360 & 167416 & 1.1 & 7.7 & 3 \\
\hline Under garments, knitted in cotton & 8462 & 155635 & 1.0 & 4.8 & 4 \\
\hline Clothing accessories, knitted or crocheted, n.e.s.. & 8472 & 148165 & 0.9 & 25.9 & 3 \\
\hline Other outer garments of textile fabrics & 8429 & 135334 & 0.9 & 11.0 & 3 \\
\hline $\begin{array}{l}\text { Yarn containing } 85 \% \text { by weight of synthetic fibers not for } \\
\text { sale }\end{array}$ & 6514 & 116999 & 0.7 & 5.3 & \\
\hline Tarpaulins, sails, awnings, sunblinds, tents etc. & 6582 & 104479 & 0.7 & 63.3 & 3 \\
\hline Molasses, whether or not decolorized & 0615 & 104340 & 0.7 & 173.1 & \\
\hline Calf leather & 6113 & 90157 & 0.6 & 59.7 & \\
\hline Articles \& manufacture of carving or molding materials & 8991 & 89536 & 0.6 & 86.9 & \\
\hline Cotton (other than linters), not carded or combed & 2631 & 88178 & 0.6 & 10.9 & \\
\hline Clothing accessories of textile fabrics & 8471 & 84306 & 0.5 & 11.9 & 2 \\
\hline Wadding, textile fabrics for use in machinery/plant & 6577 & 84118 & 0.5 & 16.5 & \\
\hline Leather of other bovine cattle and equine leather & 6114 & 83438 & 0.5 & 5.3 & 2 \\
\hline Fruit, fresh or dried, n.e.s. & 0579 & 82213 & 0.5 & 6.3 & \\
\hline Under garments, excluding shirts, of textile fabrics & 8442 & 75051 & 0.5 & 42.4 & 3 \\
\hline Footwear & 8510 & 71615 & 0.5 & 1.3 & 3 \\
\hline Yarn of discontinuous synthetic fibers, containing $<85 \%$ & 6516 & 68738 & 0.4 & 12.0 & \\
\hline Cotton waste (including pulled or garnetted rags) & 2633 & 68330 & 0.4 & 135.1 & \\
\hline Shellac, seed lac, stick lac, resins, gum-resins etc. & 2922 & 65450 & 0.4 & 121.9 & \\
\hline Medicaments(including veterinary medicaments) & 5417 & 64425 & 0.4 & 0.6 & 2 \\
\hline Suits \& costumes, women's, of textile fabrics & 8432 & 57622 & 0.4 & 32.2 & 3 \\
\hline Dresses, skirts, suits etc, knitted or crocheted & 8452 & 54717 & 0.4 & 12.2 & 3 \\
\hline Jackets, blazers of textile fabrics & 8424 & 51655 & 0.3 & 7.8 & 5 \\
\hline Sacks and bags, of textile materials & 6581 & 48950 & 0.3 & 24.6 & 2 \\
\hline Blouses of textile fabrics & 8435 & 44655 & 0.3 & 4.3 & 4 \\
\hline Suits, men's, of textile fabrics & 8422 & 44215 & 0.3 & 11.2 & 2 \\
\hline Petrol. oils \& crude oils obtained from bitumin. minerals & 3330 & 41562 & 0.3 & 0.3 & \\
\hline Cutlery & 6960 & 36524 & 0.2 & 5.4 & \\
\hline Fish, frozen (excluding fillets) & 0342 & 33359 & 0.2 & 2.8 & 3 \\
\hline Dresses, women's, of textile fabrics & 8433 & 32341 & 0.2 & 5.8 & 3 \\
\hline
\end{tabular}

Source: WITS Database, World Bank

Notes: ${ }^{1}$ Percentage share of product in total exports (1998), ${ }^{2}$ Number of South Asian countries exporting the product to ROW with RCA $>1$ 


\begin{tabular}{|c|c|c|c|c|c|}
\hline \multicolumn{6}{|c|}{ BANGLADESH } \\
\hline Product Description & SITC & \begin{tabular}{|c|} 
Exports to \\
the ROW (\$ \\
,000)
\end{tabular} & $\begin{array}{l}\text { Share in } \\
\text { Exports }^{1}\end{array}$ & RCA & Similarity count $^{2}$ \\
\hline Shirts, men's of textile fabrics & 8441 & 1800670.635 & 17.9 & 162.0 & 3 \\
\hline Trousers,breeches etc. of textile fabrics & 8423 & 823807.312 & 8.2 & 57.9 & 4 \\
\hline Under garments,knitted in cotton & 8462 & 814786.106 & 8.1 & 41.7 & 4 \\
\hline Jerseys,pull-overs,twinsets,cardigans,knitted & 8451 & 789594.072 & 7.8 & 42.7 & 4 \\
\hline Jackets,blazers of textile fabrics & 8424 & 752309.232 & 7.5 & 189.3 & 5 \\
\hline Other outer garments of textile fabrics & 8439 & 626723.351 & 6.2 & 32.3 & 4 \\
\hline Crustaceans and molluscs, fresh, chilled, frozen etc. & 0360 & 520926.073 & 5.2 & 39.8 & 3 \\
\hline Other outer garments of textile fabrics & 8429 & 403506.932 & 4.0 & 55.0 & 3 \\
\hline Overcoats and other coats, men's & 8421 & 352670.427 & 3.5 & 197.6 & 2 \\
\hline Blouses of textile fabrics & 8435 & 345224.473 & 3.4 & 54.9 & 4 \\
\hline Coats and jackets of textile fabrics & 8431 & 234826.603 & 2.3 & 36.8 & 2 \\
\hline Other outer garments \& clothing, knitted & 8459 & 211251.477 & 2.1 & 12.6 & 4 \\
\hline Sacks and bags, of textile materials & 6581 & 181030.002 & 1.8 & 151.6 & 2 \\
\hline Leather of other bovine cattle and equine leather & 6114 & 164438.505 & 1.6 & 17.5 & 2 \\
\hline Jute \& other textile based fibers, nes,raw/processed & 2640 & 145069.52 & 1.4 & 1541.4 & \\
\hline Fabrics, woven, of jute or of other textile based fibers & 6545 & 144440.307 & 1.4 & 860.6 & \\
\hline Cotton fabrics, woven, bleach. mercerized dyed, printed & 6522 & 120061.618 & 1.2 & 7.6 & 4 \\
\hline Yarn of text, fibers, n.e.s., incl. yarn of glass fibers & 6519 & 118116.578 & 1.2 & 54.4 & \\
\hline Twine, cordage, ropes \& cables.\& manufacture thereof & 6575 & 99811.967 & 1.0 & 66.3 & \\
\hline Other sporting goods and fairground amusements & 8947 & 88782.65 & 0.9 & 10.1 & 2 \\
\hline Tea & 0741 & 85026.045 & 0.8 & 37.5 & 3 \\
\hline Under garments, knitted, of synthetic fibers & 8463 & 84031.241 & 0.8 & 19.8 & 3 \\
\hline Tarpaulins, sails, awnings, sunblinds, tents etc. & 6582 & 82372.618 & 0.8 & 83.3 & 3 \\
\hline Footwear & 8510 & 76773.862 & 0.8 & 2.3 & 3 \\
\hline Under garments, excl. shirts, of textile fabrics & 8442 & 70874.853 & 0.7 & 66.8 & 3 \\
\hline Mineral or chemical fertilizers, nitrogenous & 5621 & 69805.084 & 0.7 & 18.9 & \\
\hline Fabrics, woven, of discontinuous synthetic fibers & 6534 & 65495.024 & 0.7 & 10.4 & \\
\hline Suits, men's, of textile fabrics & 8422 & 55207.7 & 0.5 & 23.2 & 2 \\
\hline Dresses, women's, of textile fabrics & 8433 & 54125.973 & 0.5 & 16.1 & 3 \\
\hline Under garments, women's, of textile fabrics & 8443 & 47203.505 & 0.5 & 46.7 & 2 \\
\hline Machinery \& appliances for particular specialized industries & 7284 & 40028.949 & 0.4 & 0.9 & \\
\hline Leather of other hides or skins & 6116 & 36803.86 & 0.4 & 29.2 & 2 \\
\hline Articles for the conveyance or packing of goods & 8931 & 35235.404 & 0.3 & 2.5 & 2 \\
\hline Bed linen, table linen, toilet \& kitchen linen etc. & 6584 & 32871.421 & 0.3 & 4.5 & 4 \\
\hline Fish, frozen (excluding fillets) & 0342 & 31688.504 & 0.3 & 4.5 & 3 \\
\hline Other fresh or chilled vegetables & 0545 & 29908.776 & 0.3 & 3.3 & \\
\hline Skirts, women's, of textile fabrics & 8434 & 29387.185 & 0.3 & 10.0 & 2 \\
\hline Suits \& costumes, women's, of textile fabrics & 8432 & 28727.58 & 0.3 & 26.7 & 3 \\
\hline Wood, simply shaped, n.e.s. & 6349 & 27712.823 & 0.3 & 135.4 & \\
\hline Dresses, skirts, suits etc., knitted or crocheted & 8452 & 24885.076 & 0.2 & 9.3 & 3 \\
\hline Lighting fixtures and fittings and parts & 8124 & 21774.716 & 0.2 & 2.2 & \\
\hline Vegetables, frozen or in temporary preservative & 0546 & 19573.926 & 0.2 & 3.1 & \\
\hline Tableware \& other articles of porcelain or china & 6664 & 19340.267 & 0.2 & 8.6 & 2 \\
\hline Optical instruments and apparatus & 8710 & 16336.537 & 0.2 & 1.3 & \\
\hline UN Special Code & 9310 & 16219.18 & 0.2 & 0.1 & 4 \\
\hline Fish, dried, salted or in brine; smoked fish & 0350 & 15535.818 & 0.2 & 6.2 & \\
\hline Pins \& needles, fittings, base metal beads, etc. & 6993 & 14964.381 & 0.1 & 10.7 & \\
\hline Fuel oils, n.e.s. & 3344 & 14623.269 & 0.1 & 1.2 & \\
\hline Construction and mining machinery, n.e.s. & 7234 & 12909.524 & 0.1 & 0.7 & \\
\hline
\end{tabular}

Source: WITS Database, World Bank

Notes: ${ }^{1}$ Percentage share of product in total exports (1998), ${ }^{2}$ Number of South Asian countries exporting the product to ROW with RCA $>1$ 


\begin{tabular}{|c|c|c|c|c|c|}
\hline \multicolumn{6}{|c|}{ SRI LANKA } \\
\hline Product Description & SITC & \begin{tabular}{|c|} 
Exports \\
to the \\
ROW \\
$\left(\${ }^{\prime} 000\right)$
\end{tabular} & $\begin{array}{l}\text { Share in } \\
\text { Exports }\end{array}$ & RCA & $\begin{array}{c}\text { Similarity } \\
\text { count }^{2}\end{array}$ \\
\hline Tea & 0741 & 1213323 & 14.0 & 605.8 & 3 \\
\hline Other outer garments of textile fabrics & 8439 & 610120 & 7.0 & 35.5 & 4 \\
\hline Under garments, knitted in cotton & 8462 & 556127 & 6.4 & 32.2 & 4 \\
\hline Blouses of textile fabrics & 8435 & 420206 & 4.8 & 75.6 & 4 \\
\hline Trousers, breeches etc. of textile fabrics & 8423 & 351763 & 4.1 & 28.0 & 4 \\
\hline Other outer garments \& clothing, knitted & 8459 & 349862 & 4.0 & 23.6 & 4 \\
\hline Shirts, men's, of textile fabrics & 8441 & 301305 & 3.5 & 30.7 & 3 \\
\hline Travel goods, handbags, briefcases, purses, sheaths & 8310 & 246126 & 2.8 & 27.8 & 2 \\
\hline Jerseys, pullovers, twinsets, cardigans, knitted & 8451 & 223113 & 2.6 & 13.7 & 4 \\
\hline Dresses, women's, of textile fabrics & 8433 & 198962 & 2.3 & 67.0 & 3 \\
\hline Jackets, blazers of textile fabrics & 8424 & 192930 & 2.2 & 54.9 & 5 \\
\hline Parts of and accessories suitable for 751.2-,752-- & 7599 & 175139 & 2.0 & 2.0 & \\
\hline Corsets, brassieres, suspenders etc. & 8465 & 170894 & 2.0 & 50.3 & \\
\hline Skirts, women's, of textile fabrics & 8434 & 160455 & 1.9 & 62.0 & 2 \\
\hline Edible nuts (excluding nuts used for the extraction of oil) & 0577 & 159539 & 1.8 & 48.2 & 2 \\
\hline Coats and jackets of textile fabrics & 8431 & 155015 & 1.8 & 27.5 & 2 \\
\hline Other tyres, tyre cases, inner tubes & 6259 & 137954 & 1.6 & 33.3 & \\
\hline Under garments, women's, of textile fabrics & 8443 & 137110 & 1.6 & 153.5 & 2 \\
\hline Footwear & 8510 & 133707 & 1.5 & 4.6 & 3 \\
\hline Clothing accessories, knitted or crocheted, n.e.s. & 8472 & 130340 & 1.5 & 43.0 & 3 \\
\hline Other precious \& semi-precious stones, unworked, cut etc. & 6673 & 121346 & 1.4 & 100.2 & 2 \\
\hline Articles of apparel \& clothing accessories, of plastic & 8482 & 120406 & 1.4 & 43.2 & \\
\hline Spices (except pepper and pimento) & 0752 & 117757 & 1.4 & 150.4 & \\
\hline UN Special Code & 9310 & 115642 & 1.3 & 0.9 & 4 \\
\hline Under garments, knitted, of synthetic fibres & 8463 & 111254 & 1.3 & 29.6 & 3 \\
\hline Tarpaulins, sails, awnings, sunblinds, tents etc. & 6582 & 106302 & 1.2 & 121.7 & 3 \\
\hline Diamonds, unworked. cut/otherwise worked not mounted/set & 6672 & 83974 & 1.0 & 3.1 & 2 \\
\hline Children s toys, indoor games etc. & 8942 & 81259 & 0.9 & 4.2 & \\
\hline Crustaceans and molluscs, fresh, chilled, frozen etc. & 0360 & 81134 & 0.9 & 7.0 & 3 \\
\hline Other outer garments of textile fabrics & 8429 & 77784 & 0.9 & 12.0 & 3 \\
\hline Dresses, skirts, suits etc, knitted or crocheted & 8452 & 70880 & 0.8 & 29.9 & 3 \\
\hline Vegetable textile fibres, n.e.s. and waste & 2659 & 66171 & 0.8 & 4100.2 & \\
\hline Tobacco, not stripped & 1211 & 61523 & 0.7 & 41.9 & 2 \\
\hline Natural rubber latex; natural rubber \& natural gums & 2320 & 57878 & 0.7 & 17.8 & \\
\hline Tableware $\&$ other articles of porcelain or china & 6664 & 50358 & 0.6 & 25.4 & 2 \\
\hline Headgear and fittings thereof, n.e.s. & 8484 & 47894 & 0.6 & 26.0 & \\
\hline Fish, fresh (live/dead) or chilled, excluding fillets & 0341 & 43815 & 0.5 & 8.6 & \\
\hline Other articles of rubber, n.e.s. & 6289 & 40140 & 0.5 & 6.0 & \\
\hline Suits \& costumes, women's, of textile fabrics & 8432 & 39253 & 0.5 & 41.4 & 3 \\
\hline Basketwork, wickerwork etc. of plaiting materials & 8997 & 37308 & 0.4 & 16.9 & \\
\hline Articles for the conveyance or packing of goods & 8931 & 36038 & 0.4 & 2.9 & 2 \\
\hline Mineral tars and products of their distillation & 3352 & 35152 & 0.4 & 14.4 & \\
\hline Overcoats and other coats, men's & 8421 & 33992 & 0.4 & 21.6 & 2 \\
\hline Other electric power machinery, parts of 771-- & 7712 & 31652 & 0.4 & 1.8 & \\
\hline Chemical products and preparations, n.e.s. & 5989 & 31564 & 0.4 & 1.2 & \\
\hline Cotton fabrics, woven, bleach. mercerized. dyed, printed & 6522 & 31458 & 0.4 & 2.3 & 4 \\
\hline Bed linen, table linen, toilet \& kitchen linen etc. & 6584 & 30987 & 0.4 & 4.8 & 4 \\
\hline Cotton fabrics, woven, unbleached, not mercerized & 6521 & 30633 & 0.4 & 9.4 & 2 \\
\hline Under garments, excluding shirts, of textile fabrics & 8442 & 29750 & 0.3 & 31.7 & 3 \\
\hline Pepper; pimento & 0751 & 27140 & 0.3 & 25.8 & 2 \\
\hline
\end{tabular}

Source: WITS Database, World Bank

Notes: ${ }^{1}$ Percentage share of product in total exports (1998), ${ }^{2}$ Number of South Asian countries exporting the product to ROW with RCA $>1$ 


\begin{tabular}{|c|c|c|c|c|c|}
\hline \multicolumn{6}{|c|}{ NEPAL } \\
\hline Product Description & SITC & \begin{tabular}{|c|} 
Export \\
s to the \\
ROW \\
$\left(\${ }^{\prime} 000\right)$
\end{tabular} & $\begin{array}{l}\text { Share in } \\
\text { Exports }\end{array}$ & RCA & $\begin{array}{c}\text { Similarity } \\
\text { count }^{2}\end{array}$ \\
\hline Carpets, carpeting and rugs, knotted & 6592 & 257858 & 48.6 & 4026.1 & 2 \\
\hline Other outer garments of textile fabrics & 8439 & 39643 & 7.5 & 37.9 & 4 \\
\hline Trousers, breeches etc. of textile fabrics & 8423 & 28797 & 5.4 & 37.5 & 4 \\
\hline UN Special Code & 9310 & 18443 & 3.5 & 2.4 & 4 \\
\hline Blouses of textile fabrics & 8435 & 15600 & 2.9 & 46.0 & 4 \\
\hline Beans, peas, lentils \& other leguminous vegetables & 0542 & 13842 & 2.6 & 111.0 & \\
\hline Bed linen, table linen, toilet \& kitchen linen etc. & 6584 & 8129 & 1.5 & 20.8 & 4 \\
\hline Under garments, knitted in cotton & 8462 & 6675 & 1.3 & 6.3 & 4 \\
\hline Ornamental articles and objects of materials of div.58 & 8933 & 6430 & 1.2 & 588.0 & \\
\hline Jewelry of gold, silver or platinum & 8973 & 4820 & 0.9 & 4.8 & 2 \\
\hline Oil seeds and oleaginous fruit, n.e.s. & 2238 & 3963 & 0.7 & 268.8 & \\
\hline Jerseys, pullovers, twinsets, cardigans, knitted & 8451 & 3371 & 0.6 & 3.4 & 4 \\
\hline Other outer garments \& clothing, knitted & 8459 & 2932 & 0.6 & 3.2 & 4 \\
\hline Articles of paper pulp, paper, paperboard, cellulose, wadding & 6428 & 2316 & 0.4 & 4.9 & \\
\hline Jackets, blazers of textile fabrics & 8424 & 1417 & 0.3 & 6.6 & 5 \\
\hline Travel goods, handbags, briefcases, purses, sheaths & 8310 & 1349 & 0.3 & 2.5 & 2 \\
\hline Clothing accessories of textile fabrics & 8471 & 1252 & 0.2 & 5.5 & 2 \\
\hline Art. of apparel \& clothing accessories, of leather & 8481 & 677 & 0.1 & 2.5 & 3 \\
\hline Manufactured articles of wood, n.e.s. & 6359 & 409 & 0.1 & 2.9 & \\
\hline Tea & 0741 & 356 & 0.1 & 2.9 & 3 \\
\hline Clothing accessories, knitted or crocheted, n.e.s. & 8472 & 258 & 0.0 & 1.4 & 3 \\
\hline Small-wares and toilet articles, feather dusters etc. & 8998 & 254 & 0.0 & 1.5 & \\
\hline Natural honey & 0616 & 140 & 0.0 & 5.9 & \\
\hline Fabrics, woven, of silk, of noil or other waste silk & 6541 & 95 & 0.0 & 1.3 & \\
\hline Beer made from malt (including ale, stout and porter) & 1123 & 74 & 0.0 & 0.3 & \\
\hline Medicaments (including veterinary medicaments) & 5417 & 57 & 0.0 & 0.0 & 2 \\
\hline Cotton fabrics, woven, bleach. mercerized, dyed, printed & 6522 & 46 & 0.0 & 0.1 & 4 \\
\hline Armored fighting vehicles, arms of war \& ammunition & 9510 & 38 & 0.0 & 0.1 & \\
\hline Manufactures of wood for domestic/decorative use & 6354 & 33 & 0.0 & 0.4 & \\
\hline Bulbs, tubers \& rhizomes of flowering or of foliage & 2926 & 31 & 0.0 & 0.2 & \\
\hline Macaroni, spaghetti and similar products & 0483 & 24 & 0.0 & 0.2 & \\
\hline Coffee, whether or not roasted or freed of caffeine & 0711 & 10 & 0.0 & 0.0 & 2 \\
\hline Vegetables, prepared or preserved, n.e.s. & 0565 & 6 & 0.0 & 0.0 & \\
\hline Gramophone records and similar sound recordings & 8983 & 5 & 0.0 & 0.0 & \\
\hline
\end{tabular}

Source: WITS Database, World Bank

Notes: ${ }^{1}$ Percentage share of product in total exports (1998), ${ }^{2}$ Number of South Asian countries exporting the product to ROW with RCA $>1$ 


\section{Annex 2. Index Methodologies}

\section{Trade Intensity Index}

The trade intensity index (TII) is a useful tool for evaluating whether a country, given the relative size of its own export market and the relative size of its partner's import market, exports to that partner as much as could be expected. The TII is defined as:

$$
I_{i j}=\left(X_{i j} / X_{i}\right) /\left[M_{j} /\left(M_{w}-M_{i}\right)\right]
$$

where $I_{i j}$, country $i$ 's exports to country $j$, is defined as the share of country $\mathrm{j}$ in country $i$ 's total exports $\left(X_{i j} / X_{i}\right)$, relative to the share of $j$ 's imports, $M_{j}$, in total world imports, net of $i$ 's imports for the rest of the world $(M w-M i)$. For those trading partners that have TIIs greater than unity, their trade relationship can be defined as "intensive" (i.e. the countries trade more than would be expected given the relative size of the market for imports).

\section{Index of Revealed Comparative Advantage}

Revealed comparative advantage measures a country's trade specialization in a commodity group and is defined as a country's sectoral share divided by the world sectoral share. $I R C A_{i j}$ equals the index of revealed comparative advantage of country $i$ in commodity $j$ :

$$
\operatorname{IRCA}_{\mathrm{ij}}=\frac{X_{\mathrm{ij}} / \mathrm{X}_{\mathrm{I}}}{\mathrm{X}_{\mathrm{wj}} / \mathrm{X}_{\mathrm{w}}}
$$

where $X_{i j}$ represents country $i$ 's export of commodity $j, X_{w j}$ represents world exports of commodity $j, X_{i}$ represents the total exports of country $I$, and $X_{w}$ represents total world exports. The index value ranges between zero and infinity with values greater than unity indicating specialization in that commodity group, while a value between zero and unity indicates no specialization in that commodity group.

\section{Complementarity Index of Trade}

The Complementarity Index measures the degree of "matching" between one country's export composition and another country's import composition. The Complementarity $\left(C_{i j}\right)$ between country $i$ 's exports and country $j$ 's imports is defined as:

(C) $I T C_{i j}=\sum_{k} \frac{X_{i w}^{k}}{X_{i w}} * \frac{M_{w w}-M_{i w}}{M_{w w}^{k}-M_{i w}^{k}} * \frac{M_{j w}^{k}}{M_{j w}}$

where $X_{i}$ and $X_{i}^{k}$ represent country $i$ 's exports of commodity $k$ and total exports, respectively; $M_{i}$ and $M_{i}^{k}$ represent country $i$ 's imports of commodity $k$ and total imports, respectively; $M_{w}$ and $M_{w}{ }^{k}$ represent the world's imports of commodity k and total imports, respectively; and $M_{j}$ and $M_{j}^{k}$ represent country $j$ 's imports of commodity $k$ and total imports, respectively. The index value ranges between zero and 100 with values greater than unity indicating complementarity between country $i$ 's exports and country $j$ 's imports. 
wb12009

C:IDocuments and Settings|WB12009\My Documentslwps3497.doc

$03 / 29 / 2005$

11:46:00

$\mathrm{AM}$ 